\title{
Dental homologies and evolutionary transformations in Caviomorpha (Hystricognathi, Rodentia): new data from the Paleogene of Peruvian Amazonia
}

\author{
Myriam Boivin $^{\mathrm{a}^{*}}$ and Laurent Marivaux ${ }^{\mathrm{a}}$ \\ ${ }^{\text {a }}$ Laboratoire de Paléontologie, Institut des Sciences de l'Évolution de Montpellier (ISE-M), c.c. \\ 064, Université de Montpellier, CNRS, IRD, EPHE, place Eugène Bataillon, F-34095 \\ Montpellier Cedex 05, France.
}

*Corresponding author. Tel: 334671449 11. Email: myriam.boivin@umontpellier.fr. 


\begin{abstract}
Dental homologies and evolutionary transformations within caviomorph rodents have long been disputed. Here, we join to these debates in providing new insights from the dental morphology of Paleogene caviomorphs from Peruvian Amazonia (Contamana and Shapaja). Their analyses and comparisons with many hystricognaths allows (1) to generalize some hypotheses previously proposed about occlusal morphology of caviomorph cheek teeth, and (2) to propose new ones. In caviomorphs, the third crest of upper teeth would correspond either to a mesoloph or to a mesolophule or to a combination of both. The transformation from a pentalophodont pattern to a tetralophodont pattern would be explained by the disappearance of the metaloph. Likewise, the transformation from a tetralophodont pattern to a trilophodont pattern is observed by the loss of the third crest. A direct transformation from a pentalophodont pattern to a trilophodont pattern is also observed. Concerning lower teeth, discrepancies of homologies are centered on the mesial cristids, which can be notably distinguished depending on their compositions and connections with other structures. The ancestral patterns of caviomorph lower molars and dp $4 \mathrm{~s}$ were likely tetralophodont and pentalophodont, respectively. However, schemes with five and four (even three) transverse cristids cannot be ruled out for the two loci, respectively.
\end{abstract}

Keywords: Caviomorph rodents, Peru, South America, dental morphology, hypotheses of homologies. 


\section{Introduction}

Homology is usually considered as a fundamental concept in biology, which 'occupies a central position in comparative studies', dixit de Pinna (1991). As part of morphological analyses, the identification of structures corresponding to primary homology (sensu de Pinna 1991) is a prerequisite, but is not always obvious and often a matter of debate. For instance, the case of the distal crests of upper teeth in caviomorph rodents (Caviomorpha Wood, 1955 or New World hystricognaths) has long been the subject of intense discussions. The diverging proposed homologies have resulted in competing hypotheses regarding the sister group identification of caviomorphs and, hence, in diverging opinions about their geographic origin. Indeed, two main hypotheses were proposed during the twentieth century:

(1) some authors have advocated that a tetralophodont pattern would be the ancestral condition for caviomorph upper teeth, and that these rodents would be closely related to North American rodents: Paramyidae or Sciuravidae (Wood 1949) and then Franimorpha (Reithroparamyinae, Protoptychidae, Prolapsus, Guanajuatomys, and later Cylindrodontidae; Wood 1980; see also Wood 1950, 1959, 1962, 1965, 1972, 1973, 1974, 1975, 1983, 1984, 1985a, b, 1993; Wood and Patterson 1959; Patterson and Wood 1982);

(2) in contrast, some others have defended the hypothesis according to which the upper teeth of caviomorphs would be primitively pentalophodont, with a pattern similar to that of Old World hystricognaths (Phiomorpha [Thryonomyidae, Bathyergoidea, and Hystricoidea] sensu Lavocat 1967). On the basis of these hypotheses of morphological homologies, an African origin of caviomorphs was postulated (Lavocat 1969, 1971, 1973, 1974a, b, 1976, 1977a, b, 1980; Hoffstetter 1971, 1972, 1975, 1976; Hoffstetter and Lavocat 1970). 
Since then, the reassessment of the potential links between North American reithroparamyids and hystricognaths (Dawson 1977; Korth 1984; Meng 1990), as well as the formalization of the caviomorph-phiomorph relationships via phylogenetic analyses based on morphological (e.g., George 1993; Luckett and Hartenberger 1993; Marivaux et al. 2002, 2004) and molecular data (e.g., Nedbal et al. 1996; Huchon et al. 2000, 2002, 2007; Huchon and Douzery, 2001; Montgelard et al. 2008; Fabre et al. 2012) marked the end of this hotly debated biogeographic issue. The hypothesis of an African origin for caviomorphs, put forward by Lavocat (and collaborators), is now a well-accepted consensus within the scientific community. However, critical factors such as the mode and precise timing of the Afro-South-American dispersal(s), and the pathways by which this (these) dispersal(s) occurred remain still entirely unknown.

Over the past decades, many authors have studied dental homologies and evolutionary patterns in caviomorphs (e.g., Jaeger 1989; Vucetich and Verzi 1994; Verzi et al. 2018), notably in erethizontoids (e.g., Candela 1999, 2002) and in octodontoids (e.g., Carvalho and Salles 2004; Candela and Rasia 2012; Candela 2015; Verzi et al. 2014, 2016, 2017, 2018). The debates regarding the dental homologies in caviomorphs have then shifted to other structures, such as the mesial cristids of lower teeth (Candela 2002; Carvalho and Salles 2004; Candela and Rasia 2012; Candela 2015; Verzi et al. 2014, 2016, 2017, 2018).

Despite the modern and Neogene high diversity of caviomorphs, the early evolutionary history of these rodents has long remained obscure. Until recently, most of the Paleogene caviomorph assemblages were primarily concentrated at middle (Bolivia, Brazil, Chili, southern Peru, and Uruguay) and high (Argentina) latitudes of South America (15/19; see Boivin et al. 2017b and citations therein). By contrast, lower latitudes have long remained poorly documented (Santa Rosa and Lircay, Peru; Foz do Breu and Cachoeira São Salvador, Brazil; Hartenberger et al. 
1984; Frailey and Campbell 2004; Ribeiro et al. 2013, Kerber et al. 2017). During the last decade, the continuing field efforts in Peruvian Amazonia (Contamana and Tarapoto areas) have led to the discovery of about twenty Paleogene localities yielding many fossils of caviomorphs (mainly dental remains; Antoine et al. 2016; Boivin et al. 2017a, b, 2018). They document three South American Land Mammal Ages (SALMA): Barrancan (late Middle Eocene; Contamana), Tinguirirican (Early Oligocene; Tarapoto, Shapaja section) and Deseadan (Late Oligocene; Contamana). The late Middle Eocene localities have so far yielded the oldest known representatives of the group in South America (Antoine et al. 2012; Boivin et al. 2017a). The studies of these fossils have revealed a rich specific diversity, most of the species being new for science (Antoine et al. 2012; Boivin 2017; Boivin et al. 2017a, b, 2018). These ancient fossils have provided unusual dental morphologies for caviomophs, the descriptions and detailed comparisons of which have led us to formulate new hypotheses regarding some structural homologies, and also to further our understanding regarding some aspects of their evolutionary trends. All these observations were at the origin of an updated dental nomenclature, which was proposed in Boivin et al., 2017a, b, 2018). In this paper, we propose a detailed overview of the dental homology and evolutionary transformation hypotheses that we have formulated in light of the dental material from the Paleogene rodent-bearing localities of Contamana and Tarapoto/Shapaja. We provide here an exhaustive morphological analysis of the fossil cheek teeth from these localities, and compare these rodents from Peruvian Amazonia to other extinct New and Old World hystricognaths as well as to extant caviomorphs.

\section{Material and methods}

\section{Material}


For this study, we considered most of the caviomorph cheek teeth available from the Eocene (Antoine et al. 2012; Boivin et al. 2017a) and Oligocene (Boivin et al. 2017b) localities of Contamana (CTA), and the Oligocene localities of Tarapoto/Shapaja (TAR; Boivin et al. 2018). For comparisons, we used a large taxonomic sampling of caviomorphs, including several extinct and extant members of the four superfamilies recorded from low, middle and high latitudes of South America. Our taxonomic material used for comparisons also included some Paleogene representatives of the Old World hystricognaths, which represent among the early hystricognaths known from Asia and Africa (e.g., Wood 1968; Marivaux et al. 2000, 2002, 2014, 2017a; Marivaux and Welcomme 2003; Sallam et al. 2009, 2011, 2012; Coster et al. 2012; Sallam and Seiffert, 2016), and are supposed to be close to the caviomorph ancestor. The comparisons were made from the literature or directly with the material (originals or casts) of several institutions. The taxa used for comparisons are listed in Supplementary Online Material.

\section{Dental nomenclature}

The terminology used here for the rodent dentition (Figures 1 and 2) is based on:

- Wood and Wilson (1936), Lavocat (1976), Candela (1999, 2002), Marivaux et al. (2002, 2004) and Antoine et al. (2012) for the cusps, crests and cristids;

- Stirton (1935), Black and Wood (1956), Fields (1957), Candela (1999), Antoine et al. (2012) and Marivaux et al. (2014, 2017a, b) for the flexi(-ds), fossett(-ids)es and stri(-ds). Compared with these authors, several modifications regarding the designation of some cusp(-id)s, loph(-id)s, and flexi(-ds) are the results of our own observations and interpretations of the material we have studied and used for comparisons. These modifications, based on distinct 
homology hypotheses, are abundantly discussed here, and were considered for the selection of characters and character states used by Boivin (2017) and Boivin et al. (submitted) for their large scale cladistic analysis of caviomorph rodents. Some of these characters and character states have already been introduced by Boivin and Marivaux in Boivin et al. (2017a, b, 2018), and used by Marivaux et al. (2017a) at a wide taxonomic scale (i.e., for Old World hystricognaths). Upper case letters are used here for the upper dentition (DP: for deciduous premolar, P: for premolar, M: for molar) and lower case letters for the lower dentition (dp: for deciduous premolar, $\mathrm{p}$ : for premolar, m: for molar).

\section{Criteria for homologies}

For the recognition of dental homologies, we followed the anatomical definition of homology (i.e., primary homology sensu de Pinna 1991), and used notably the interdependent criteria of topology and connectivity between structures (Rieppel 1988, 1994). We also used two other criteria: the position of structures relative to each other and their orientation (the latter aspect being applied only for loph(-id)s). We did not used directly the shape and size criteria for homology identification, but we considered the variations of both the shape and size (in surface and height) of the structures in one taxon or closely related taxa, which could be informative for the understanding of homology recognition and evolutionary tendencies. The latter aspect joins the third criterion of Remane (1952) for identifying homologies: criterion of continuity or connection through intermediate forms (the latter being either ontogenetic stages or systematically intermediate species). For each taxon, when the available material was sufficient, we examined the intraspecific variation (inter-individual variation) in analysing dental specimens 
of several individuals. We focused with special interest on juvenile specimens (when available) having germs or little worn teeth, for which the dental structure recognition was obvious (not erased by wear). The morphological comparisons between many New and Old World hystricognaths allowed the proposition of dental homology hypotheses (conjectures of homologies) that can be applicable at the caviomorph scale, or at least for the less or moderately specialized taxa. We compared our proposed hypotheses of dental homologies with alternative plausible hypotheses proposed and discussed in the literature (synthetized in the section 'Historical review and current state of caviomorph dental structures', see below). The dental homology hypotheses proposed here have been evaluated by a cladistic assessment (Boivin 2017; Boivin et al. submitted; i.e, test of congruence; see Riepple 1988; de Pinna 1991; Riepple and Kearney 2002) in order to provide a phylogenetic context and to identify structures shared from a common ancestor (secondary homology sensu de Pinna 1991). In this paper, the schematic line drawings focus exclusively on the occlusal morphology and transformations of some parts (specified in each case) of considered loci. The other occlusal areas and structures remain voluntarily unchanged (i.e., the schemes do not refer to any occlusal pattern of a specific taxon).

\section{Institutional abbreviations}

MACN: Museo Argentino de Ciencias Naturales 'Bernardino Rivadavia', Buenos Aires, Argentina; MLP: Museo de Ciencias Naturales de La Plata, La Plata, Argentina; MMP: Museo de Ciencias Naturales de Mar del Plata, Lorenzo Scaglia, Mar del Plata, Argentina; MNHN: Musée national d'Histoire naturelle, Paris, France; MNHN-Bol-V: Museo Nacional de Historia Natural, La Paz, Bolivia; MN-UFRJ: Museu Nacional, Universidade Federal do Rio de Janeiro, 


\author{
Rio de Janeiro, Brazil; MPEF: Museo Paleontológico Egidio Feruglio, Trelew, Argentina; MPM- \\ PV: Museo Regional Provincial 'Padre Manuel Jesús Molina', Río Gallegos, Argentina; MUSM: \\ Museo de Historia Natural de la Universidad Nacional Mayor San Marcos, Lima, Peru; MVZ: \\ Museum of Vertebrate Zoology, University of California, Berkeley, USA; UATF: Universidad \\ Autónoma Tomás Frías, Potosí, Bolivia; UM: Universite de Montpellier, Montpellier, France.
}

\title{
Other abbreviations
}

GSP: Yale-Geological Survey of Pakistan; Z5R: Zallah 5 Rodent Locality.

\begin{abstract}
Historical review and current state of caviomorph dental structures (homologies and nomenclature)
\end{abstract}

\section{Upper teeth}

Stirton (1935), then Wood and Wilson (1936) were the first to propose/formalize a nomenclature of cusps, crests, cristids and flexi(-ids), applicable to the cheek tooth morphology of rodents, a nomenclature which was consistent with the tribosphenic plan characteristic of Theria, as defined by Simpson (1936) based on Osborn (1907). Throughout the description of Platypittamys (Scarritt Pockett, Argentina; Deseadan), Wood (1949) applied the Wood and Wilson nomenclature to caviomorphs. Their proposition was subsequently completed and formalized by Wood and Patterson (1959), and later by Patterson and Wood (1982). For tetralophodont teeth, these authors recognized successively on a mesiodistal axis, an antero-, meta-, hypo- and posterolophid on lower teeth, and an antero-, proto-, meta- and posteroloph on upper teeth. According to these 
authors, the tetralophodonty of upper molars was likely the ancestral condition in caviomorphs, and the pentalophodonty was developed secondarily in some groups, by the addition of a neoloph situated between the metaloph (then constituting the third loph) and the posteroloph (the fifth loph; Figure 3(A)). The pentalophodonty of lower molars (as well as for $\mathrm{dp} 4 \mathrm{~s}$ and $\mathrm{p} 4 \mathrm{~s}$ ) was also interpreted with the addition of a neolophid (Figures 4(A) and 5(A)).

After studying the fossil rodents from Salla (Bolivia; Deseadan), Hoffstetter and Lavocat (1970) and Lavocat (1976) proposed, however, another interpretation of the crest homologies for describing the pentalophodonty of upper molars, a view which was compatible with that of Schaub (1953) (Figure 3(B)). For these authors, the configuration of the teeth would be similar to that found in the Theridomyidae and Old World hystricognaths (Phiomorpha sensu Lavocat 1967): the third crest would be a mesoloph (that can be linked to a transversal crest stemming from the anterior arm of the hypocone; Lavocat 1976, figure 4, p. 71) labially connected to a mesostyle, and the fourth crest would be a metaloph labially connected to the metacone (Figure 3(B)). They interpreted the tetralophodonty of caviomorphs as a simplification (i.e., loss of the metaloph) from a pentalophodont ancestral state. They provided several arguments in favor of this hypothesis:

- $\quad$ in addition to the formerly known pentalophodont taxa Protosteiromys (Cabeza Blanca and La Flecha, Argentina; Deseadan; Wood and Patterson 1959), the fact that three new genera from Salla (Branisamys, Incamys, and Sallamys) also exhibited a pentalophodont pattern of upper molars, revealed that the pentalophodonty was rather common among early caviomorphs (known in the 1970s) and likely primitive; 
- the taxa with a well-defined and long metaloph (Branisamys and Protosteiromys) exhibit brachydont teeth, a crown state which would rather indicate a plesiomorphous condition for the metaloph configuration;

- Incamys shows a vestigial metaloph as in Thryonomys (i.e., the modern African cane rat), in which this crest originates from the well-developed metaloph of Miocene 'phiomorphs';

- Sallamys has a P4 that is structurally much simpler than the condition observed in Platypittamys, and also exhibits a very large infraorbital foramen, a condition which would suggest that the absence of $\mathrm{P} 4$ complexity is not primitive;

- the Salla rodents are very similar to the early 'phiomorphs' known in the 1960s (i.e., Early Oligocene of Fayum, Egypt; Wood 1968), notably in the morphology of their upper molars. Their pattern can be explained by the reductions or loss of connections between crests from a fundamental pattern illustrated by the African Phiomys andrewsi (Early Oligocene; Wood 1968; Lavocat 1976, figure 4(D), p. 71).

The two competing hypotheses have generated hotly debated issues regarding caviomorph geographic origins, notably the North American origin defended by Wood (and collaborators) versus the African origin defended by Lavocat (and collaborators) (see Introduction). It is worth noting that Butler (1985) questioned Wood's hypothesis of homologies (Wood 1949), inasmuch as the dental pattern of upper molars would be a non-functional configuration (i.e., the paracone being closer to the metacone than the protocone to the hypocone). This argument was later used by Candela (1999) who also noted in erethizontoids that the third labial cusp is larger in both surface and height than the second one, thereby suggesting a pattern including a mesostyle- 
metacone complex, the latter topology being more consistent with the Lavocat's hypothesis of homologies (Lavocat 1976). Jaeger (1989) and Vucetich and Verzi (1994) followed Lavocat's view but diverged regarding the pattern of simplification leading to a tetralophodonty from a pentalophodont scheme. Based primarily on Salla rodents, Jaeger (1989) interpreted the third crest of tetralophodont upper molars of Sallamys as the result of a fusion between the metaloph and the mesoloph. In this context, the latter was not considered to be the homologuous structure as that observed in Old World hystrognaths. These crests, although occupying an analogous position would be developed independently in each group as a result. Vucetich and Verzi (1994) also analyzed the Salla rodent fauna in performing a more extensive comparative analysis, and considering many other extinct and extant taxa. According to them, the transformation from a pentalophodont to a tetralophodont pattern would also include the fusion of the metaloph with another crest, but the latter would be the posteroloph instead of the mesoloph. These authors recognized that a fusion between the mesoloph and the metaloph is possible, like on the M2 of the Branisamys holotype (MNHN SAL 102, Lavocat 1976: plate 2.4). Nevertheless, this fusion would be particular in Branisamys, generating a part of the intraspecific variation observed in this taxon. Bryant and McKenna (1995) also advocated that the pentalophodonty of upper molars is the ancestral condition of caviomorphs, but in considering that the third crest of Old World hystrognaths and caviomorphs is neither a mesoloph nor a metaloph, but rather a mesolophule (Figure 3C). This structure was originally defined by Flynn et al. (1986) in Baluchimyinae (Chapattimyidae sensu Flynn et al. 1986; Hystricognathi incertae sedis sensu Marivaux et al. 2002) as being the crest originating from the metaconule and running towards the labial edge of the tooth (Flynn et al. 1986; Marivaux 2000; Marivaux et al. 2000, 2002, 2004; Marivaux and Welcomme 2003). In studying the morphology of the upper molars of fossil and modern 
erethizontoids, Candela (1999) showed that the third crest is either continuous or discontinuous in this superfamily. When discontinuous, this crest is formed by a lingual portion linked to a metaconule (corresponding to a mesolophule) and a neoformed labial portion stemming from the mesostyle (Figure 3(D)). Given these observations, Candela (1999) proposed a prepentalophodont step as the ancestral condition in erethizontoids, a pattern in which the metaloph is still connected to the hypocone. Subsequently, this connection would be lost, and the metaloph would be linked to the posteroloph. A continuous third crest would be formed by the fusion of the mesolophule with the neocrest of the mesostyle.

Over the past three decades, the hypothesis of an African origin of caviomorphs, closely related to the 'phiomorphs', has gained strong support. The phiomorph-caviomorph relationship derives from a corpus of morpho-anatomical and genetic data (see Introduction), other than the dental morphology only. Such a strongly supported phylogenetic relationship between Old and New World hystricognaths then supports Lavocat's dental homology hypothesis, which has now reached a well-accepted consensus, althrough some authors have continued to follow the nomenclature proposed by Wood (Carvalho and Salles 2004; Frailey and Campbell 2004). Since the 1990s, the discussions have progressively focused on the homology of the third crest on upper molars, considered as either a mesoloph or a mesolophule (see above). Marivaux (2000) studied the early radiation of Paleogene rodents via a phylogenetic approach, in order to better understand the patterns of dental transformations through time, and to identify homoplasic structures. In related papers, Marivaux et al. $(2002,2004)$ proposed a general dental terminology applicable to the whole group (at least to their Paleogene representatives and more recent forms moderately derived from a dental point of view). In this nomenclature, the third crest of upper 
molars can be formed by (1) a lingual part, the mesolophule (sensu Flynn et al. 1986) that is connected to the metaconule (conule that can disappear in some groups like caviomorphs and advanced 'phiomorphs'), and (2) a labial part, named mesoloph, originating from the mesostyle and running lingually (Figure 3(E)). This nomenclature was consistent with that proposed by Candela (1999). However, Marivaux et al. (2004) recognized only a mesolophule as the third crest in the sampled Paleogene Ctenohystrica (caviomorphs included, but limited to few Deseadean forms; the Afro-Asian hystricognaths being also less known and documented at that time), the mesoloph being observed only in some Ischyromyiformes (Anomaluroidea, Zegdoumyidae, Eutypomyidae, Gliridae, Sciuravidae, and Theridomyidae). This terminology has been applied by Marivaux for the original description of caviomorphs from CTA-27, which are among the most ancient representatives of the group known thus far (Barrancan; Antoine et al. 2012; Figure 3(F)). The dental morphology of some of these rodents (Cachiyacuy and Canaanimys), characterized by pentalophodont upper molars, is very similar to that of Old World hystricognaths and especially to some Paleogene African forms. The discovery of these early caviomorph taxa from the late Middle Eocene of Peruvian Amazonia has provided key elements, which have strengthened support for Lavocat's hypotheses regarding caviomorph origin and dental evolutionary patterns (i.e., African origin of caviomorphs and ancestral pentalophodont pattern of upper molars in this group; Hoffstetter and Lavocat 1970; Lavocat 1976).

\section{Lower teeth}

Although less controversial than for upper teeth, the structural homologies on lower teeth have often been questioned, notably regarding the identification of the mesial cristids. According to Candela (2000), based on Wood and Wilson (1936), the second cristid of lower molars in 
erethizontids would be a metalophulid II or a mesolophid, depending on the connected cuspids (protoconid-metaconid or mesoconid-mesostylid, respectively; Figure 4(B)). Candela (2002) studied the dp4 morphology of extinct and extant erethizontids and compared it with that of dp4s of some fossil Old World hystricognaths (i.e., Baluchimys, Gaudeamus, Lindsaya, Phiomys, and Tsaganomys). The morphologies being very similar, she concluded that they are probably homologous, and that the ancestral pattern of erethizontid dp4s (and probably, more generally, of hystricognaths dp4s) is pentalophodont, contrary to Wood and Patterson (1959). On lower teeth, based on Wood and Wilson (1936), she recognized successively an anterolophid, metalophulid II, mesolophid, hypolophid and posterolophid (Figure 5(B1)). The tetralophodont scheme would be developed subsequently in Hypsosteiromys and some specimens of Erethizon dorsatum by the loss of the mesolophid (Figure 5(B2)). The hexalophodont pattern of some erethizontids (i.e., Eosteiromys homogenidens, E. dorsatum, Steiromys detentus, S. duplicatus, and Coendou prehensilis) would be also achieved from the pentalophodont ancestral configuration, by the addition of a neolophid between the anterolophid and the metalophulid II (Figure 5(B1)). Candela (2002) identified the same hexalophodont morphology on one dp4 of Branisamys (UM GN 014; Hartenberger 1975; Patterson and Wood 1982), a taxon from Salla initially described as a dasyproctid cavioid (Lavocat 1976). Based on this observation, as well as on other cranial and dental features characterizing erethizontids, Candela (2002) advocated a potential affiliation of Branisamys to the New World porcupines.

The nomenclatures used so far for the studies on hystricognaths (and more generally other rodent groups) have often been inconsistent across authors. This lack of uniformity (standard usage) has somewhat engendered a degree of confusion in the terminology: e.g., 
cingulum/anterior cingulid, anterolophid, paracristid/paralophid, metalophid, metalophid I, protolophid/protocristid, metalophid II, metalophulid I, metalophulid II, and posterior arm of the protoconid (e.g., Wood 1968; Dawson 1984; Flynn et al. 1986; Korth 1994; Kumar et al. 1997; Wang 1997; Meng and Wyss 2001). The nomenclature proposed by Marivaux et al. (2004), modified from that of Wood and Wilson (1936), allowed, to some extent, for a first step of clarification of these issues, notably on the homologous structures used for discriminating the anterior cristids of lower molars. Following this terminology, basal rodentiaforms display a trigonid with a paralophid/paracristid linking the protoconid to the reduced paraconid, as well as a metalophulid II (protolophid/protocristid = long posterior arm of protoconid) connecting the protoconid to the metaconid (e.g., Tribosphenomys). The paraconid is subsequently lost and the paralophid joins lingually the metaconid, then becoming a metalophulid I (e.g., Archetypomys, Cocomys). A low anterior cingulid can be present in some "ctenodactyloids" and "ischyromyoids". In the latter group, this cingulid iteratively developed to reach a lophid status, becoming the anterolophid, and in some cases replacing the metalophulid I, which is lost in some forms (for a synthesis, see Marivaux et al. 2004, p. 120). In this context, Marivaux et al. identified on caviomorph lower molars a metalophulid I, a metalophulid II, a hypolophid, and a posterolophid (Figure 4(C)). According these authors, these same cristids are present on $\mathrm{dp} 4 \mathrm{~s}$, and a mesolophid can be additionally developed between the metalophulid II and the hypolophid (Figure 5(C)). This terminology was used by Antoine et al. (2012). Candela and Rasia (2012) extended this nomenclature to dp4s and lower molars of echimyids (the more diversified octodontoid group) and questioned previous terminologies of Patterson and Wood (1982; Figures 4(A) and 5(A)) and Carvalho and Salles (2004; Figures 4(A) and (D), 5(A) and (D)) based on cladistic assessments (Figures 4(E) and 5(E)). Following their results, the tetralophodonty would 
be the ancestral condition of lower molars in echimyids, the pentalophodonty and trilophodonty (which appears at least three times independently) would be derived. Candela and Rasia (2012) shared, however, the view of Patterson and Wood (1982) and Carvalho and Salles (2004) in the interpretation of the second cristid of pentalophodont lower molars (in Hoplomys), which would be a neoformed structure called neolophid (Figure 4(E1)). As for erethizontids (Candela 2002), the pentalophodonty would be the plesiomorph condition for echimyid dp4s, and the tetralophodonty would be the apomorph state. Lastly, these authors interpreted the "crest C" of dp4s and lower molars of some echimyids (i.e., Clydomys, Euryzygomatomys, Lonchothrix, Mesomys, Proechimys, Therisomysops, or Trinomys) as being a metalophulid II, more or less long and curved (Figures 4(E2) and 5(E2)). This cristid was originally defined by Carvalho and Salles (2004) as a metalophid merged with a neolophid (Figures 4(D) and 5(D)). Recently, Verzi et al. $(2014,2016,2017)$ have considered the second cristid of lower molars in some octodontoids as a mesolophid (Myocastor, Acaremys in Verzi et al. [2014, figure 5(D), p. 763]; Acaremys and gen. et sp. nov. in Verzi et al. [2017, figure 5(B) and (F), p. 418]) or a combination of a metalophulid II with a mesolophid (e.g., Proechimys, Myocastor, Acarechimys in Verzi et al. [2016, figures 13, p. 96-98]; and potentially Acarechimys, Plesiacarechimys, and Protacaremys in Verzi et al. [2017, figures 4(C), (F) and (G), p. 417]; Figure 4(F1)). In the case of the lower molars of Hoplomys, Verzi et al. (2016) have interpreted the second cristid ("crest C"/neolophid sensu Carvalho and Salles [2004] and Candela and Rasia [2012], respectively) as a metalophulid II, and the third cristid (metalophulid II sensu Candela and Rasia [2012]) as a mesolophid (Figure 4(F2)). Following Arnal (2012) and Candela and Rasia (2012), Candela (2015) questioned the hypothesis advanced by Verzi et al. (2014, and subsequently Verzi et al. 2016, 2017). According to Candela (2015), in all octodontoids, the second cristid of lower molars would correspond to a 
metalophulid II with notable variation in orientation, size and shape, but not to a mesolophid. Recently, Verzi et al. (2018), analyzing dp4s of caviomorphs of the four superfamilies and ancient representatives of New and Old World hystricognaths, have considered that a hexalophodont scheme is the ancestral condition for this locus in caviomorphs. This scheme would be characterized by an anterolophid, metalophulid I, metalophulid II, mesolophid, hypolophid and posterolophid (Figure 5(F)). From this ancestral condition, more simple patterns would derive with firstly the loss of the metalophulid I.

\section{Results}

\section{Upper teeth}

The third transverse crest

Marivaux (2000) and Marivaux et al. $(2002,2004)$ have highlighted the third crest of the upper molars, which can comprise a lingual part, the mesolophule stemming from the metaconule (conule that can disappear in caviomorphs), and a labial part, the mesoloph originating from the mesostyle. Based on the available taxonomic sample, it was shown that the mesoloph is present more specially in some Ischyromyiformes (sensu Marivaux et al. 2004), and that the third crest of the upper molars in Ctenohystrica (including caviomorphs [but limited to Incamys, Branisamys, Sallamys, and Platypittamys]) corresponds only to a mesolophule (see section 'Historical review and current state of caviomorph dental structures'). However, the New World hystricognaths included in the analysis were limited and inufficient to appreciate variability of the third crest configuration (works otherwise focused on Old World hystricognaths). In parallel, Candela (1999) observed that the third crest of erethizontid upper molars can be discontinuous, and in this case, in addition to a mesolophule, there is a labial crest neoformed from the mesostyle. 
Following the nomenclature proposed by Marivaux et al. (2004), this labial crest is an equivalent of the mesoloph.

On several upper teeth of early caviomorphs from the Eocene of Contamana (e.g., MUSM $1873,2801,2819,2832)$, the third crest is clearly discontinuous and formed by two portions: a mesoloph and a mesolophule (Figure 6). The study of the entire fossil material from Contamana and Tarapoto/Shapaja has revealed that the third crest morphology is very variable (Boivin et al. 2017a, b, 2018). Indeed, it can be composed of the mesoloph and mesolophule, connected either with each other (Figure 6(A)) or not (Figure 6(B)). It can also be only formed by the mesolophule (e.g., general case of upper molars of Mayomys; Figure 6(C) and (D)) or only by the mesoloph (e.g., general case of upper molars of three species of Eoincamys from Tarapoto/Shapaja; Figure 6(E) and (F)) (Boivin et al. 2018). Besides, the mesoloph and mesolophule are also strongly variable in terms of length (Figure 6(A-F)), orientation and connections with other elements (i.e., with the mesostyle, anterior arm of the hypocone, metaloph, or posteroloph). The third crest composition is sometimes hardly interpretable, notably when (1) this crest is fully transverse from the mesostyle to anterior arm of hypocone without discontinuity or mesiodistal pinch-point (Figure 6(G)), or (2) it displays several discontinuities or mesiodistal pitch-points (Figure 6(H)). When no interpretation/distinction can be made, the term "third transverse crest" is then used. In addition to erethizontoids (Candela, 1999), other fossil and modern caviomorphs, such as species of Santa Rosa, those of Salla, but also Australoprocta, Garridomys, Eoviscaccia, Willidewu, Protadelphomys, Proechimys, or Mesomys display upper molars with a mesoloph, accompanied or not by a mesolophule (Lavocat 1976; Patterson and Wood 1982; Vucetich and Bond 1984; Vucetich and Verzi 1991; Kramarz 1998, 2001a; Frailey and Campbell 2004; Kramarz et al. 
2013). In this context, the observations made by Candela (1999) on erethizontoid upper molars must be generalized to the whole caviomorph group and for all upper loci (i.e., P4, DP4, and M13).

\section{Terminology of flexi}

The flexus nomenclature of upper teeth used in Boivin et al. (2017a,b) follows that of Candela (1999). For pentalophodont teeth, this nomenclature recognizes, labially a paraflexus, mesoflexus, metaflexus and posteroflexus, and lingually the hypoflexus. Nevertheless, it is not consistent with the original definitions of the metaflexus and mesoflexus proposed by Black and Wood (1956). According to these authors, the metaflexus is distal to the mesoflexus and should be the posteroflexus sensu Candela (1999). The third crest being a secondary formation with respect to the ancestral pattern of rodents (see Marivaux et al. 2017a, b), the mesoflexus sensu Black and Wood (1956) corresponds to the mesoflexus plus metaflexus sensu Candela (1999). In Boivin et al. (2018), we proposed a new terminology in order to distinguish both flexi separated by the third crest: the mesial mesoflexus (mesoflexus sensu Candela 1999) and the distal mesoflexus (metaflexus sensu Candela 1999) (Figure 7).

\section{Pentalophodont, tetralophodont and trilophodont patterns}

Old and New World fossil evidence and phylogenetic inference (e.g., Marivaux et al. 2002, 2004; Antoine et al. 2012; Sallam and Seiffert, 2016; Boivin 2017; Boivin et al. 2017a, submitted) substantiate the hypothesis that the ancestral occlusal pattern of caviomorph upper molars is composed of five transverse crests (see section 'Historical review and current state of caviomorph dental structures'). As for the upper molars, the ancestral condition of P4s and DP4s 
is aslo considered as a pentalophodont scheme. However, on the basis of the phylogenetic results of Boivin (2017) and Boivin et al. (submitted), the characters corresponding to the presence/absence of the metaloph on P4s and DP4s (see coding of the characters 68 and 115 in Boivin 2017 and Boivin et al. submitted) have an ambiguous distribution in the basal branches of caviomorphs. These ambiguities can be explained by an important polymorphism of these characters in stem-caviomorphs (e.g., Cachiyacuy contamanensis or Tarapotomys subandinus) and their non-coding for some taxa without documented P4 and/or DP4. According to the nomenclature developed and adopted in this paper (Figures 1 and 2; see the paragraph 'The third transverse crest' above), an anteroloph, protoloph, third transverse crest (mesoloph and/or mesolophule), metaloph and posteroloph can therefore be distinguished on pentalophodont upper teeth.

In caviomorphs, the tetralophodont pattern, deriving from the pentalophodont ancestral scheme (transformation cladistically supported in Boivin 2017 and Boivin et al. submitted), is frequently developed on upper molars (Figure 8). Several taxa from Contamana (primarily Eocene localities) and Tarapoto/Shapaja demonstrate of the transformation from a pentalophodont pattern to a tetralophodont pattern: Eoespina sp. from CTA-51, Cachiyacuy contamanensis, Cachiyacuy kummeli, Canaanimys maquiensis and cf. Eoespina sp. from CTA27, Pozomys ucayaliensis and Cachiyacuy cf. contamanensis 2 from CTA-29, Chambiramys sylvaticus from CTA-61 (Late Oligocene), as well as Eoincamys valverdei and cf. Tarapotomys sp. from TAR-20 and TAR-21, Tarapotomys subandinus, Tarapotomys mayoensis and Mayomys confluens from TAR-01 (see Boivin et al. 2017a, b, 2018). In these taxa, the metaloph tends to be lost: it is reduced and seems to merge with the posteroloph, especially in advanced stages of wear 
(Figure 8). In these taxa, the metacone is usually linked to the posteroloph and tends also to merge with the latter (subsumed), thereby forming a posteroloph-metacone-metaloph complex in the posterolabial part of the tooth (Figure 8). Nevertheless, the metacone is sometimes still distinct and well-defined, as in Eoincamys valverdei. Similar observations were previously made in other caviomorphs (e.g., Incamys or Draconomys; Vucetich and Verzi 1994; Vucetich et al. 2010a; Verzi et al. 2016) that led Vucetich and Verzi (1994) to propose the hypothesis according to which a tetralophodont pattern would derive from a pentalophodont pattern, notably by the reduction of the metaloph subsumed within the posteroloph (Figure 8; see section 'Historical review and current state of caviomorph dental structures'). This pattern of occlusal transformation seems to be the rule in caviomorphs and to have occurred iteratively during the Paleogene. Some specimens (e.g., MUSM 2792-2794 from CTA-27) show a metaloph reduced to a very short spur nonetheless. Therefore, a loss of the metaloph (by complete reduction not by incorporation within the posteroloph) cannot be ruled out in some cases (Figure 8). Vucetich and Verzi (1994, p. 66) also seem to consider as possible complete reduction (= loss) of the metaloph: 'primero, el metalofo se reduce o se fusiona al pósterolofo, dando como resultado el primer patrón tetralofodonte'. Contrary to some Old World hystricognaths such as Paraphiomys and Thryonomys, no caviomorph seems to develop a tetralophodont pattern as the result of the reduction of the third crest on upper molars.

Vucetich and Verzi (1994) defined two main types of tetralophodont patterns on upper molars, depending on the morphology of the third crest (mesoloph sensu Vucetich and Verzi 1994). The first pattern is characterized by a complete third crest stretching from the mesostyle to the anterior arm of the hypocone, whereas for the second pattern, this same crest is more reduced and 
is lingually linked to the posteroloph (Figure 8). In the first case, the third crest can be composed of a mesoloph and/or a mesolophule, whereas in the second case, it would correspond to a mesoloph (backwardly curved), the mesolophule being absent (or lost).

The first scheme is typical of octodontoids but it is also observed in some erethizontoids (Eopululo, Hypsosteiromys, ?Neosteiromys tordillense, Steiromys detentus, Neosteiromys bombifrons, and Protosteiromys pattersoni; Vucetich et al. 1993, 2010b; Candela 2000, 2004; Frailey and Campbell 2004; Pérez et al. in press) and in several taxa considered here as stemcaviomorphs (e.g., Cachiyacuy, Canaanimys, Eoespina, Pozomys, Ucayalimys, Plesiosteiromys, or Tarapotomys; see Boivin 2017 and Boivin et al. submitted). In octodontoids (e.g., Platypittamys or Dudumus; Wood 1949; Arnal et al. 2014), the tetralophodont pattern of upper molars is associated with four main cusps: the paracone, protocone, hypocone and a cusp situated labiodistally, usually joined to the posteroloph with wear. Owing to its large size (in height and surface) and its distal position on the occlusal surface, the latter cusp has often - and logically been considered as a metacone (e.g., Vucetich and Kramarz 1993; Vucetich and Verzi 1996; Arnal and Vucetich 2015; Arnal et al. 2014). However, in some cases, this distolabial cusp may be a large and displaced mesostyle. This new nomenclatural assumption is supported by several observations:

- some upper molars of the octodontoid Protadelphomys (Vucetich and Bond 1984; Vucetich et al. 1992) retain a reduced metaloph associated with a metacone positioned very distally and slightly lingually, and which appears smaller than the mesostyle;

- some octodontoids (e.g., Galileomys antelucanus; Vucetich and Kramarz 2003) have on some of their upper molars a third transverse crest, which clearly originates from this labiodistal 
cusp. In Galileomys antelucanus, the third crest is lingually extended and connected to the anterior arm of the hypocone. A short mesolophular spur is sometimes distinct. This morphology recalls the condition found in some taxa such as Cachiyacuy and Eobranisamys javierpradoi, and thus can be interpreted as a third crest essentially formed by a long mesoloph stemming from the mesostyle. A metacone-metaloph complex is highly doubtful, the metaloph being very rarely connected to the anterior arm of the hypocone in caviomorphs. A metaloph-anterior arm of the hypocone connection is only observed in two ancient caviomorphs (and basal): Cachiyacuy and Canaanimys. Aditionnally, the metaloph seems to disappear in octodontoids, as observed in Plesiacarechimys or Draconomys (Vucetich and Vieytes 2006; Vucetich et al. 2010a);

- lastly, the abundant taxon in TAR-01, Mayomys confluens, shows affinities with octodontoids (Boivin 2017; Boivin et al. 2018, submitted). The morphology of its upper molars appears intermediary (for considered characters), between the ancestral pentalophodont pattern and the tetralophodont pattern typical of octodontoids. Such a configuration highlights the understanding regarding the identification of the labiodistal cusp. In Mayomys, the tetralophodont scheme is dominant, with a metaloph sometimes vestigial but absent in most cases. A metacone, distal to the mesostyle, is clearly distinct on some M3s (MUSM 3462 and 3480; Boivin et al. 2018, figure 4S, p. X) and merged with the posteroloph and/or the mesostyle with wear (e.g., MUSM 3461; Boivin et al. 2018, figure 4N, p. X). On M1-2s, only one labiodistal cusp is present. It is interpreted as a mesostyle due to, (1) its position moderately close to the paracone; (2) a third crest (usually a mesolophule) broadly transverse and aligned with this cusp (both structures can be joint), and (3) the presence of a very extensive distal flexus. The metacone is subsumed within the posteroloph in most cases. The MUSM 3462 M3 has a large and distally displaced mesostyle, with a labiodistal-linguomesial obliquity of the third crest, and a marked 
expansion of the distal flexus, which are typical features of octodontoids (e.g., Caviocricetus, Dudumus).

However, it is worth noting that on some specimens of Sallamys pascuali from Salla (MNHN-Bol-V-004256, -007382, -007589, -007823, and -011054), the mesostyle appears associated (i.e., very closely situated or twinned) to a distal cusp, interpretable as a metacone. On these specimens, the mesostyle can be larger than the metacone (MNHN-Bol-V-007589), but the reverse is also observed (MNHN-Bol-V-007382 and -011054). Hence, total loss of the metacone may not have occurred in all octodontoids. A fusion between the mesostyle and the metacone is also possible (as in the erethizontoid Erethizon and Coendou; Boivin 2017 and Boivin et al. submitted), and as such the hypothesis of loss of the mesostyle instead of the metacone cannot be completely excluded in this superfamily.

The second scheme of tetralophodonty defined by Vucetich and Verzi (1994) would be a characteristic of chinchilloids. Indeed, this morphology is developed in several fossil chinchilloids (e.g., Scleromys angustus, Eoviscaccia australis, and Garridomys curnunuquem; Ameghino 1887; Kramarz 2001a; Kramarz et al. 2013), taxa originally described as dasyproctids but which would show closer affinities with chinchilloids (e.g., Microscleromys cribriphilus, Eoincamys pascuali, and Eoincamys parvus; Walton 1997; Frailey and Campbell 2004; Boivin et al. 2018), and in the octodontoid Protadelphomys latus (Vucetich and Bond 1984). Such a case of tetralophodonty also tends to be developed in other taxa such as: the chinchilloid Eoincamys ameghinoi, Eoincamys valverdei, Chambiramys sylvaticus, Incamys bolivianus, Maquiamys praecursor, Scleromys quadrangulatus and Microscleromys paradoxalis, and the octodontoid Sallamys pascuali (Lavocat 1976; Patterson and Wood 1982; Walton 1997; Frailey and Campbell 
2004; Kramarz 2006a; Boivin 2017; Boivin et al. 2017b, 2018, submitted). In these species, the mesoloph is reduced and it loses its connection(s) with the anterior arm of the hypocone or the mesolophule (which is strongly reduced or absent), its lingual part is oriented toward the posteroloph and, in some cases, connects to the latter. In some of these taxa (E. valverdei, $C$. sylvaticus, I. bolivianus, S. pascuali, and P. latus), a short metaloph can be still present. With wear, the mesoloph and mesostyle tend to be subsumed within the posteroloph (and the metaloph, if it is still present), thus forming a large distolabial complex/platform as observed on upper molars of S. pascuali, E. valverdei, and species of Scleromys. This complex is suspected on M12s of Willidewu, which have three transverse crests including a very thick posteroloph (Vucetich and Verzi 1991, 1994). This configuration being very similar to that observed for the metaloph, Vucetich and Verzi (1994) and Verzi et al. (2016) have proposed that the transformation from a tetralophodont pattern to a trilophodont pattern can be explained by the loss of a crest (i.e., mesoloph sensu Vucetich and Verzi 1994; mesolophule sensu Verzi et al. 2016; called third transverse crest here) merging with the posteroloph. This transformation allows explaining the dental pattern of upper molars of Chambiramys shipiborum from CTA-32 (Late Oligocene). Indeed, this taxon displays trilophodont upper molars, with a mesostyle distally displaced and strongly linked to the posteroloph and structures associated to the posteroloph, which are likely the relicts of the third crest or its connection with the posteroloph (on MUSM 2849 and 2852; Boivin et al. 2017b, figure 4B, C, p. 77). With wear (MUSM 2851; Boivin et al. 2017b, figure 4D, p. 77), all of these structures merge and form a large complex (i.e., platform).

The observations made here, supported by phylogenetic results of Boivin (2017) and Boivin et al. (submitted) and consistent with the proposition of Vucetich and Verzi (1994), allow to explain the transformation from a pentalophodont pattern to a tetralophodont pattern: the 
metaloph would merge with the posteroloph or it would be lost. Concerning the tranformation from a tetralophodont pattern to a trilophodont pattern, in this case it is the third crest (mesoloph sensu Vucetich and Verzi 1994; mesolophule sensu Verzi et al. 2016) which would merge in fine with the posteroloph or would disappear, the metaloph being already absent or subsumed (indistinct) within the posteroloph (Figure 8). Nevertheless, these transformations do not necessarily occur in an ordored fashion (i.e., a trilophodont scheme deriving from a tetralophodont scheme, itself deriving from the pentalophodont scheme). As a matter of fact, some taxa, such as E. valverdei, still have a metaloph in addition to the reduced third crest, all of these structures tending to merge with the posteroloph. These taxa would then illustrate a direct transformation from a pentalophodont to a trilophodont pattern (Figure 8).

Interestingly, in the extant octodontoid Euryzygomatomys, the trilophodonty of upper molars seems not to follow a scheme of occlusal transformations presented above. Indeed, its trilophodont pattern would be linked to the loss of the labial protoloph instead of the third crest (always present). The slightly worn teeth of a specimen attributed to this taxon (MLP 16 VII0211; Figure 9) are characterized by an isolated cusp, positioned to the labial extremity of the first transverse crest (i.e., anteroloph), and another labial cusp connected to the apparent second crest. With dental wear, the first cusp tends to be connected to the anteroloph. It can be interpreted as a paracone. In that context, the cusp directly posterior to this paracone would then be a mesostyle, and the crest linked to this style would be the third transverse crest (mesoloph/mesolophule), thereby forming a transverse crest in second position. However, the possibility exists that this isolated buccal cusp is rather a neoformation, which would invalidate our interpretation regarding the trilophodonty of this taxon. 
The posteroloph spur

A short and longitudinal spur (Figure 10), situated on the mediolingual part of the posteroloph, can be observed in several taxa from Contamana (Eocene and Oligocene) and Tarapoto/Shapaja: Cachiyacuy contamanensis, Eobranisamys javierpradoi, Chambiramys shipiborum, Maquiamys praecursor, Palaeosteiromys amazonensis, Eoincamys valverdei, Eoincamys parvus, cf. Tarapotomys sp. of TAR-20 and TAR-21, Tarapotomys subandinus, Tarapotomys mayoensis, Kichkasteiromys raimondii, and Shapajamys labocensis (Boivin 2017; Boivin et al. 2017a, b, 2018, submitted). It is also present in other caviomorphs such as the species of Santa Rosa, those of Salla, Draconomys, Australoprocta, Garridomys, Microscleromys, or Coendou (Walton 1997; Kramarz 1998; Kramarz et al. 2013; Vucetich et al. 2010a; see the coding of the character 214 in Boivin 2017 and Boivin et al. submitted). Being usually associated to the metaloph, this spur has often been interpreted as a part or a relict of this crest (Boivin et al. 2017a, b, 2018), but from our observations and comparisons, it seems likely that this spur is a neoformation because:

- $\quad$ it is developed from the posteroloph;

- it is slightly connected to the metaloph in most cases, and it is sometimes independent of it (Figure 10(A) and (B));

- it can be present althrough the metaloph is absent (or completely subsumed within the posteroloph) (Figure 10(C) and (D));

- it can be also connected to the third crest and notably to the mesoloph (e.g., E. valverdei, E. parvus, and T. mayoensis) (Figure 10(D)).

\section{Lower teeth}


Posterior arm of the protoconid, neomesolophid, mesolophid and neocristids on lower molars In most caviomorphs, the second transverse cristid of lower molars would correspond to a posterior arm of the protoconid (= metalophulid II; Candela 2000, 2015; Marivaux 2000; Marivaux et al. 2002, 2004; Arnal and Vucetich 2011, 2015; Antoine et al. 2012; Arnal, 2012; Candela and Rasia 2012; Kramarz et al. 2013; Arnal et al. 2014; see section 'Historical review and current state of caviomorph dental structures'). Some authors recognize that a mesolophid can form the second cristid instead of a metalophulid II (in erethizontoids; Candela 2000) or in association with the metalophulid II (in octodontoids; Verzi et al. 2014, 2016, 2017). However, there are competing interpretations regarding that second cristid, notably in octodontoids. Indeed, contrary to the opinion of Verzi et al. (2014, 2016, 2017), Arnal (2012), Candela and Rasia (2012) and Candela (2015) consider that in octodontoids, the second cristid of lower molars is not a mesolophid but a metalophulid II that varies in orientation and length (see section 'Historical review and current state of caviomorph dental structures').

Like the third crest of upper teeth, the configuration of the second transverse cristid is highly variable on lower molars and p4s of taxa from Contamana and Tarapoto/Shapaja, especially in Cachiyacuy contamanensis (CTA-27). In the latter, the second transverse cristid of lower molars is usually formed by two portions of fluctuating length and orientation: (1) a labial portion stemming from the protoconid (the posterior arm of the protoconid), and (2) a lingual portion originating from the mesostylid (Figure 11(A) and (B)). The latter, not previously identified, has been recently called a neomesolophid in Boivin et al. (2017a, b, 2018). It is worth noting that the posterior arm of the protoconid and the neomesolophid can be connected together (Figure 11(A)) or disconnected (Figure 11(B)), and in some cases, only the posterior arm of the protoconid (Figure 11(C) and (D)) or the neomesolophid (Figure 11(E) and (F)) forms the second cristid (see 
Boivin et al. 2017a, figure 8, p. 21). A posterior arm of the protoconid and neomesolophid are also recognisable on $\mathrm{p} 4 \mathrm{~s}$ of $C$. contamanensis (Boivin et al. 2017a, figure 7, p. 20). As for the third crest of upper teeth, it is sometimes difficult to determine the composition of the second cristid of lower teeth (Figure $11(\mathrm{G})$ and $(\mathrm{H})$ ). The other taxa described from Contamana and Tarapoto/Shapaja have lower molars that differ regarding the development of these two cristids: both cristids are present (e.g., Cachiyacuy kummeli, Canaanimys maquiensis, Palaeosteiromys amazonensis, cf. Tarapotomys sp. of TAR-20 and TAR-21, and Tarapotomys mayoensis), only the neomesolophid is developed (e.g., Chambiramys sylvaticus, Eoincamys cf. pascuali of TAR-01, Tarapotomys subandinus, and Tarapotomys mayoensis), only the posterior arm of the protoconid is developed (e.g., Mayomys confluens), or neither cristid is present (Chambiramys shipiborum and Tarapotomys mayoensis) (see Boivin et al. 2017a, b, 2018). Other fossil and modern caviomorphs, such as species of Santa Rosa, those of Salla, Hypsosteiromys, Steiromys, Australoprocta, Garridomys, Scleromys, Drytomomys, Prostichomys, Erethizon, Myocastor, Proechimys or Mesomys (Fields 1957; Lavocat 1976; Patterson and Wood 1982; Kramarz 1998, 2001b, 2006a; Candela 2000; Frailey and Campbell 2004; Kramarz et al. 2013), clearly have a neomesolophid, which is associated or not with a posterior arm of the protoconid. The "crest C" defined by Carvalho and Salles (2004) on lower molars of some echimyids (e.g., Clydomys, Euryzygomatomys, Lonchothrix, and Mesomys) was interpreted by Candela and Rasia (2012) as being a metalophulid II, which would have lost its connection with the protoconid, and developed a link with the metalophulid I (see section 'Historical review and current state of caviomorph dental structures'). Nevertheless, this cristid would correspond most likely to a neomesolophid, with the labial extremity connected to the metalophulid I. 
Several p4s and lower molars of $C$. contamanensis (CTA-27, late Middle Eocene; MUSM 1879, 1914, 1915, 2676-2678, 2689, 2692, 2701, 2708, and 2714; Antoine et al. 2012; Boivin et al. 2017a) show additional and unusual structures (cristids and/or cuspids) between the second transverse cristid and the hypolophid. Some of these structures are developed from the hypolophid, and as such, are considered as neoformations. Otherwise, it is difficult to establish criteria of homology for these structures, notably those stemming from the ectolophid, which can be interpreted either as neoformations or as residual parts of an ancestral mesolophid (Boivin et al. 2017a; Figure 12). Among all p4s and lower molars attributed to C. contamanensis, only one specimen (the MUSM 2678 p4) displays one of these additional cristids stemming from a cuspid situated at the level of the ectolophid, and that could be interpreted as a mesoconid. Some lower molars seem to bear a mesoconid-like cuspid, but without supernumerary cristid associated with it. These structures are not found in other taxa from Contamana or Tarapoto/Shapaja. The mesolophid is commonly developed but very variable and slender in some 'baluchimyines' and 'phiomorphs' of the Old World from the Eocene to the Oligocene: Bugtimys, Hodsahibia, 'Acritophiomys', Phiomys, 'Waslamys', and Gaudeamus hylaeus (see Marivaux and Welcomme 2003; Jaeger et al. 2010; Sallam et al. 2009, 2011, 2012). Otherwise, the mesolophid is present and well developed in many groups of Ischyromyiformes (e.g., Anomaluroidea, Theridomorpha and Cricetidae; see Marivaux et al. 2004, 2017b). It is therefore possible that basal caviomorphs (including C. contamanensis) inherited this structure from their African common ancestor. It is usually considered that the ancestral pattern of caviomorph lower molars is tetralophodont (e.g., metalophulid I, second cristid, hypolophid, and posterolophid). But, considering that earliest caviomorphs would have inherited a mesolophid from their African hystricognath ancestor (and not developed this structure independently), the possibility exists that a pentalophodont pattern 
characterized earliest caviomorphs. This ancestral pattern would have been rapidly supplanted by the tetralophodont scheme (i.e., without mesolophid; Figure 12).

It is worth noting that the modern caviomorph Dasyprocta can have pentalophodont lower molars (Figure 12) characterized by:

- a second transverse cristid clearly formed by a posterior arm of the protoconid and another cristid stemming from the metaconid (metaconid cristid or metaconid spur, see below);

- a third cristid between the second transverse cristid and the hypolophid. It is composed of a lingual part corresponding potentially to a neomesolophid, and a labial part stemming from the ectolophid, which can be interpreted as a mesolophid.

In other taxa observed and compared to the material of Contamana and Tarapoto/Shapaja in the context of this study (Coendou, Branisamys, Cephalomys, and Luantus), the second transverse cristid can be distally displaced on lower molars, and notably on m3s. The second cristid is then close to the hypolophid and would correspond to a mesolophid (at least for its labial part, sometimes connected to a neomesolophid; Figure 12). In addition, some specimens of extant erethizontoids (MNHN MO-1909-241 and MNHN MO-1909-242, originally assigned to Sphiggurus insidiosus and probably attributable to Coendou insidiosus following the synonymy proposed by Voss 2011) have pentalophodont lower molars, characterized by the simultaneous presence of a posterior arm of the protoconid and a mesolophid (Figure 12). The presence of a mesolophid in erethizontoids had previously been indicated by Candela (2000). Verzi et al. $(2014,2016,2017)$ consider that the second cristid of lower molars of some octodontoids is a 
mesolophid or the association of a metalophulid II with a mesolophid. As noted by Verzi et al. (2016, figure 3, p. 98), a very short mesolophid can be developed posteriorly to the second transverse cristid in Protacaremys prior and Caviocricetus lucasi (Figure $14(\mathrm{G})$ and (J)). In contrast, in other taxa figured by Verzi et al. (2016, figures 1 and 2, p. 96-97; Figures 13, 14), the second cristid is positionned anteriorly, and it is linked to the protoconid and/or the mesostylid, and/or the metaconid (see below). Given these connections, this cristid seems not to correspond to a mesolophid (Figures 13,14), which is in agreement with the hypothesis selected by Arnal (2012), Candela and Rasia (2012) and Candela (2015).

Another type of pentalophodonty, different from that previously mentioned for Dasyprocta and Shiggurus, is found on lower molars of the octodontoid Hoplomys (Carvalho and Salles 2004; Figure 13(A1, A3)) and several fossil erethizontoids (e.g., Branisamyopsis australis, Branisamyopsis praesigmoides, Steiromys duplicatus, and Neosteiromys pattoni; Candela 2000, 2003, 2004; Kramarz 2004). It corresponds to an addition of a neolophid in the anteroflexid, situated between the metalophulid I and the second cristid (Patterson and Wood 1982; Candela 2000, 2003, 2004; Carvalho and Salles 2004; Candela and Rasia 2012; Figures 12 and 13(A3)). This neolophid often originates from a mesiolingual cuspid, which is also neoformed (neoconid), and situated between the metaconid and the mesostylid. MUSM 2861 is the only lower molar from CTA-32 that is assigned to Palaeosteiromys amazonensis (Boivin et al. 2017b, figure 4L, p. 77). With a neolophid in the anteroflexid, this molar displays a pattern equivalent to that of $B$. australis, B. praesigmoides, S. duplicatus, N. pattoni and Hoplomys (Boivin et al. 2017b).

In several caviomorphs (including Dasyprocta), a cristid is developed in the anteroflexid of lower molars. This cristid is neither a posterior arm of the protoconid, nor a mesolophid, nor a 
neomesolophid, and nor to the neolophid aforementioned. It extends labially from the metaconid, being usually short or very short. It is named here metaconid cristid or metaconid spur (Figures 12 and 13; Boivin 2017; Boivin et al. submitted). For most taxa displaying that metaconid cristid, the developement of this structure is very variable. Besides, for a given species, this cristid can be present or absent (see coding of the character 369 in Boivin 2017 and Boivin et al. submitted). It can be then expected that the development of this structure is convergent among several taxa. It is frequently found in octodontoids (e.g., Platypittamys, Sallamys, Willidewu, Acaremys, Dudumus, and Galileomys; Wood 1949; Lavocat 1976; Patterson and Wood 1982; Vucetich and Verzi 1991; Kramarz 2004; Arnal and Vucetich 2015; Arnal et al. 2014). In that group, this metaconid cristid can be connected to the posterior arm of the protoconid, and in some cases accompanied by other cristulids stemming from the metalophulid I, the metaconid or even the posterior arm of this cuspid (when the latter is still present; Figures 13, 14). Verzi et al. $(2016,2017)$ recognized a metalophulid II and a mesolophid on lower molars of some octodontoids (the two cristids can be associated to form the second transverse cristid; see above). Nevertheless, given its position, orientation and connections with other structures, the cristid interpreted by Verzi et al. (2016, figures 1-2, p. 96-98; Figure 13(K); Figure 14(B-H), (J) and (K)) as a metalophulid II seems more likely a metaconid cristid (in Acarechimys minutus, Acaremys, Caviocricetus lucasi, Deseadomys arambourgi, Sallamys pascuali, Protacaremys prior, Protadelphomys sp., and P. latus), and/or a supernumerary cristulid (in Proechimys cuvieri, P. roberti, Protadelphomys sp., and Sallamys quispea; Figure 13(B), (D) and (I); Figure 14 (C) and (E)). Similarly, the cristid considered as a mesolophid by Verzi et al. (2016, figures 1 and 2, p. 96-97) corresponds more likely to:

- $\quad$ a neomesolophid (in Mesomys hispidus and Trinomys dimidiatus; Figure 13(E) and (F)); 
- a posterior arm of the protoconid seperated from a neomesolophid (m2 of Proechimys cuvieri in Verzi et al. (2016, figure 1b', p. 96; Figure 13(B));

- a posterior arm of the protoconid linked to a neomesolophid (in Myocastor coypus, $\mathrm{m} 1$ of Proechimys cuvieri in Verzi et al. (2016, figure 1b', i', p. 96; Figure 13(B), (I) and (J));

- a posterior arm of the protoconid, seperated from a metaconid cristid (in Acarechimys minutus, Protacaremys prior, P. latus, Protadelphomys sp., Sallamys pascuali, and $S$. quispea; Figure 13(K); Figure 14(C-G));

- a posterior arm of the protoconid, connected to a metaconid cristid (Protacaremys prior; Figure 14(H)).

On lower molars of Lonchotrix emiliae, Proechimys poliopus, P. roberti, Trinomys elegans figured by Verzi et al. (2016), the homology of the cristid situated in second position, stemming from the lingual margin of the molars, and which is labially connected to the metalophulid I, is somewhat ambiguous. This cristid would correspond either to a neomesolophid or to a metaconid cristid (Figure 13(C), (D), (G) and (H)). Verzi et al. (2017, figure 4F, G, p. 417) described a "lingual extension of the metaconid" on m1s of Plesiacarechimys and Protocaremys, which would not correspond to the metaconid cristid (it is not directly connected to the metaconid), but rather to a neoformation.

Among the Oligocene taxa from Contamana and Tarapoto/Shapaja, several of them show a tendency toward a reduction of the second cristid of lower molars: Chambiramys sylvaticus, Eoincamys cf. pascuali, Tarapotomys subandinus, Tarapotomys mayoensis and Mayomys confluens (Boivin et al. 2017b, 2018). In caviomorphs, this reduction seems to have occurred convergently several times, and two usual types of patterns can then be distinguished (Figure 12): 
- in the first, the posterior arm of the protoconid tends to disappear and the neomesolophid to be reduced (e.g., Tarapotomys subandinus, T. mayoensis, Chambiramys sylvaticus, Eoincamys, Incamys, Garridomys, and Eoviscaccia; Lavocat 1976; Patterson and Wood 1982; Kramarz 2001a; Frailey and Campbell 2004; Kramarz et al. 2013; Boivin et al. 2017b, 2018);

- $\quad$ in the second, the neomesolophid tends to disappear and the posterior arm of the protoconid (or ?mesolophid) to be reduced (e.g., Luantus, Mayomys, Draconomys, Leucokephalos, and Xylechimys; Patterson and Pascual 1968; Kramarz 2006b; Vucetich et al. 2010a, 2015; Boivin et al. 2018).

In caviomorphs, several taxa display trilophodont lower molars (e.g., Tarapotomys mayoensis, Chambiramys shipiborum, Phoberomys, Luantus, Sallamys, Ethelomys, and Deseadomys; Wood and Patterson 1959; Lavocat 1976; Patterson and Wood 1982; Kramarz 2006b; Vucetich et al. 2015; Rasia and Candela 2017; Boivin et al. 2017b, 2018). The trilophodont pattern is achieved by the loss of the second cristid, and seems to be linked or to have implied (Figure 12):

- the fusion of a reduced neomesolophid with the metalophulid I. This fusion is observed for instance on worn molars of T. mayoensis, Incamys and Scleromys. This structural rearrangement recalls that observed on upper molars, notably the fusion of the metaloph and third crest with the posteroloph (see above);

- the fusion of the metaconid cristid (or associated cristulids; see previous paragraph) with the metalophulid I. This fusion occurs on worn molars of Sallamys;

- the complete disappearance of the neomesolophid and/or the posterior arm of the protoconid (or ?mesolophid; e.g., T. mayoensis, C. shipiborum, Luantus, and Sallamys). 
In caviomorphs, p4s develop equivalent structures to those observed on lower molars (i.e., posterior arm of the protoconid, mesolophid, neomesolophid, neolophid, and metaconid cristid). The second transverse cristid can also be reduced or lost on p4s (e.g., Draconomys, Leucokephalos, and Deseadomys), as well as the metalophulid I (e.g., Cephalomys arcidens, Asteromys, Perimys, or Galileomys; Wood and Patterson 1959; Kramarz 2002, 2004). The hypolophid, entoconid and posterolophid are merged and form a distal thick cristid on $\mathrm{p} 4 \mathrm{~s}$ of some octodontoids (Platypittamys, Deseadomys, Galileomys, Acaremys, and Sciamys). However, the fossil taxa being more rarely documented by $\mathrm{p} 4 \mathrm{~s}$ than lower molars, the evolution of these different structures on $\mathrm{p} 4 \mathrm{~s}$ is more difficult to appreciate.

\section{Nomenclature of the $\mathrm{dp} 4 \mathrm{~s}$}

According to Candela (2002) and Candela and Rasia (2012), the ancestral pattern of the dp4s of echimyids and erethizontids (and more broadly of hystricognaths) is pentalophodont. These authors recognize on $\mathrm{dp} 4 \mathrm{~s}$ of these groups: a metalophulid I, a metalophulid II, a mesolophid, a hypolophid and a posterolophid. In contrast, Verzi et al. (2018) consider that a hexalophodont scheme is the ancestral condition for this locus in caviomorphs. This scheme would be characterized by the presence of an anterolophid, in addition to the metalophulid I, metalophulid II, mesolophid, hypolophid and the posterolophid (see section 'Historical review and current state of caviomorph dental structures').

Considering the Old and New World hystricognaths, the identification of the mesialmost cristid seems to be somewhat more complicated than that proposed by Candela (2002), Candela and Rasia (2012) and Verzi et al. (2018). In some caviomorphs, the anterior cristid on dp4s 
appears to be a metalophulid I, which is formed by the anterior arm of the protoconid and/or the anterior arm of the metaconid. In Eocene and Oligocene Old World hystricognaths, the trigonid of the dp4s is strongly variable and can display an anterior cingulid/anterolophid/anteroconid, and/or elements of the metalophulid I (which are usually separated and reduced), and/or the posterior arm of the protoconid/metaconid cristid. In some of these Old World hystricognaths (e.g., Baluchimys barryi, Lindsaya derbugtiensis; Flynn et al. 1986), there is no direct connection between the anterior cingulid/anterolophid/anteroconid and the anterior arms of the protoconid and metaconid, but the latter arms are often oriented toward the anterior cingulid/anterolophid/anteroconid. In contrast, in some others ('Acritophiomys' bowni, Birkamys korai, Hodsahibia azrae, Lophibaluchia, Phiomys hammudai, Protophiomys aegyptensis, and Protophiomys algeriensis; Jaeger et al. 1985, 2010; Flynn et al. 1986; Sallam et al. 2009, 2012; Sallam and Seiffert 2016), the anteroconid (and often its anterior and posterior arms as well) and/or the anterior cingulid, can be connected to the metalophulid I. So, the anterior cristid on dp4s in caviomorphs (and in Gaudeamus too) could be a more complex structure, composed of a metalophulid I, an anteroconid, its arms, and of an anterior cingulid/anterolophid. We propose here to name this mesialmost cristid on caviomorph $\mathrm{dp} 4 \mathrm{~s}$ an anterocristid.

Rk1: the specimen GSP 21352 illustrated by Verzi et al. (2018, figure 1A, p. 2) and originally described as a dp4 of Baluchimys ganeshapher by Flynn et al. (1986, figure 17J, p. 30), does not correspond in fact to this baluchimyine taxon, but more likely to Downsimys, a taxon with potential anomalurid or even cylindrodontid or bathyergid affinities (see Marivaux 2000; Marivaux et al. 2004, 2017b). In contrast, we consider that GSP 21353 described as a p4 of $B$. ganeshapher by Flynn et al. (1986, figure 17I, p. 30), would be rather a dp4. The p4 of $B$. 
ganeshapher would be not documented (this assumption was already assumed in former works of Marivaux et al. (2002, 2004, etc.).

Rk2: the specimen Z5R-163 illustrated by Verzi et al. (2018, figure 1B, p. 2) was originally described by Coster et al. (2012, figure 4N, p. 243) as a dp4 of Metaphiomys aff. schaubi. However, according to Marivaux et al. (2017a), the specimens attributed to this taxon rather correspond to a morphology corresponding to Acritophiomys (A. bowni), a genus also considered as a junior synonym of Phiomys. In this context, the material of Metaphiomys aff. schaubi from Zallah (Central Libya; Coster et al. 2012) should be rather designated as belonging to a species of Phiomys.

The dp4s from CTA-27 (late Middle Eocene) attributed to Cachiyacuy contamanensis and $C$. kummeli are pentalophodont, except one, MUSM 1880, attributed to C.contamanensis, with almost hexalophodont scheme (Antoine et al. 2012, figure 2k, p. 1322). Except for the mesialmost cristid (see above), the nomenclature proposed by Candela (2002) and Candela and Rasia (2012) is applicable on all dp4s. However, some clarifications are appropriate:

- the second transverse cristid does not always correspond to a long posterior arm of the protoconid (= metalophulid II). Indeed, it can be composed of a posterior arm of the protoconid plus a short cristid developed from the metaconid (MUSM 1880, 1888, 2663, 2665, and 2673; Boivin et al. 2017a; Figure 15(A-E)). This short cristid is the equivalent of the metaconid cristid or metaconid spur of p4s and lower molars;

- the mesolophid can be aligned and connected to a lingual cristid stemming from the mesostylid (MUSM 1880; Figure 15(A) and (E-H)). This lingual cristid is the equivalent of the neomesolophid of $\mathrm{p} 4 \mathrm{~s}$ and lower molars; 
- mesial and distal ectolophids can be recognized (Figures 14 and 15). The distal ectolophid is longitudinal and links the mesolophid to the hypolophid. The mesial ectolophid is longitudinally oriented in its anterior part and linguodistally oriented in its posterior part. It links the protoconid to the mesolophid and the distal ectolophid. On some dp4s of $C$. contamanensis (MUSM 1880, 2464, and 2671), the mesial ectolophid appears composed of different structures: two cristulids on MUSM 2464 and 2671, and one large cuspid with anterior and posterior arms on MUSM 1880 (Antoine et al., 2012; Boivin et al. 2017a). This cuspid is connected to a cristid situated between the second cristid and the mesolophid, and which seems to be composed of two cristulids. This cuspid would be a mesoconid labially displaced, but it is interpreted here as a neocuspid, as well as the cristid that is connected to it (neolophid; Figures 16, 17). Indeed, these structures are developed on only one dp4 of C. contamanensis (MUSM 1880). Paleogene Old World hystrognaths do not have structures with equivalent morphology and position (e.g., 'Acritophiomys', Protophiomys, Phiomys, 'Waslamys', Metaphiomys, Gaudeamus; Wood 1968; Sallam et al. 2009, 2011, 2012; Jaeger et al. 2010; Coster et al. 2012; Marivaux et al. 2014). Conversely, the mesoconid, at the intersection of the two ectolophids and mesolophid, tends to disappear in these taxa.

As for the p4s and lower molars, the metaconid cristid and neomesolophid are present on dp4s of other fossil taxa from Contamana (e.g., Cachiyacuy cf. contamanensis 1 of CTA-51; Boivin et al. 2017a) and Tarapoto/Shapaja (e.g., Caviomorpha indet. 1. of TAR-21, Eoincamys cf. pascuali of TAR-01, and Mayomys; Boivin et al. 2018), and elsewhere in South America (e.g., Branisamys, Incamys, Drytomomys, Eosallamys, and Galileomys; Fields 1957; Patterson and 
Wood 1982; Frailey and Campbell 2004; Kramarz 2004; see coding of the characters 317 and 329 in Boivin 2017 and Boivin et al. submitted). Verzi et al. (2017, figure 4A, F, G, p. 417 and figure 5A, p. 418) have described a "lingual extension of the metaconid" on dp4s, in notably Ameghinomys constans, Protocaremys avunculus, Plesiacarechimys koenisgwaldi and in Acaremys (Sciamys principalis). This would be the metaconid cristid in Ameghinomys and Protocaremys, whereas it could be rather a neoformation in the other taxa (in which it seems to be not directly connected to the metaconid). As for the lower molars, the "crest C" defined by Carvalho and Salles (2004) on dp4s of some echimyids (see Candela and Rasia (2012) and 'Historical review and current state of caviomorph dental structures') would correspond more likely to a neomesolophid with a labial extremity connected to the anterocristid. Within caviomorphs, the mesial ectolophid of the dp4s has variable morphology (Figure 16): it is more or less long, mesially connected or not to the protoconid, with or without neocuspid, and it can be aligned with the third cristid (mesolophid and/or neomesolophid; e.g., Caviomorpha indet. 5 and Cavioidea or Chinchilloidea indet. of CTA-29, Eobranisamys, Branisamys; Patterson and Wood 1982; Frailey and Campbell 2004; Boivin et al. 2017a) or with the distal ectolophid and hypolophid (e.g., E. cf. pascuali of TAR-01, Eoviscaccia, Drytomomys; Fields 1957; Kramarz 2001a).

Considering our interpretation of the mesialmost cristid homology on caviomorph dp4s, the ancestral condition of the dp4s would not then be hexalophodont in caviomorphs. However, although an ancestral pattern of $\mathrm{dp} 4 \mathrm{~s}$ in caviomorphs would be probably pentalophodont, a scheme with four (even three) transverse cristids is not entirely excluded, because: 
- the morphology of the dp4s in the oldest known caviomorphs strongly varies, notably in the development of the second and third cristids, which are sometimes short (e.g., MUSM 1895, 2670; Antoine et al. 2012; Boivin et al. 2017a);

- $\quad$ two other dp4s, MUSM 2645 and 2651, from two more ancient levels yielding caviomorphs (CTA-47 and CTA-51), have undeveloped third cristid (Boivin et al. 2017a, figure 5.1, 5.5, p. 10; Figure 17);

- $\quad$ the dp4s of some African hystricognaths ('Acritophiomys', Protophiomys, Phiomys, 'Waslamys', Metaphiomys, and Talaphiomys; Wood 1968; Sallam et al. 2009, 2012; Jaeger et al. 2010; Coster et al. 2012; Marivaux et al. 2014) variably have second and third cristids complete, reduced or absent.

If we take into consideration that the tetralophodonty (or trilophodonty) is the ancestral condition on caviomorph dp4s, the development of the third (even of the second) cristid would be a convergent feature between Old World hystrognaths and caviomorphs.

Like MUSM 1895 and 2670, other dp4s (e.g., MUSM 2843, 2845, and 3302) from Contamana (Late Oligocene) and Tarapoto/Shapaja (Early Oligocene), exhibit a tetralophodont pattern, which is explained by the absence of the third cristid (Boivin et al. 2017b, 2018; Figure 17). The dp4s attributed to Mayomys are variable and can be tetralophodont (Boivin et al. 2018). On these dp4s, the mesolophid can be either complete or reduced, or even absent, and the posterior arm of the protoconid can be complete or reduced, but always present (Boivin et al. 2018; Figure 17). Candela (2002) interpreted the tetralophodont pattern of the dp4s of Hypsosteiromys and some specimens of Erethizon dorsatum, as resulting from the loss of the mesolophid. The cristid in second position on the dp4s of Hypsosteiromys (MACN 52-176, 
MACN A 52-177, MLP 84-111-10-1, and MNHN col 54) seems to be however formed by two connected cristids (Figure 17), which are:

- a lingual part, which is transverse (MLP 84-111-10-1 and MNHN col 54) or labiomesially oriented (MACN 52-176 and MACN A 52-177), very distally positioned and stemming from a cuspid on the lingual margin of the teeth. Given its position and orientation, this cristid likely corresponds to a neomesolophid linked to a mesostylid;

- a second part, which is linguodistally oriented, and appearing in a position intermediate between the usual posterior arm of the protoconid and mesolophid. Although it is located far from the protoconid (especially on the dp4 of the specimen MLP 84-111-10-1), it would more likely correspond to a posterior arm of the protoconid, notably owing to its obliquity.

According to Candela (2002), some erethizontids (i.e., Eosteiromys homogenidens, E. dorsatum, Steiromys detentus, S. duplicatus, and Coendou prehensilis) have dp4s with a hexalophodont pattern, which is characterized by the addition of a neolophid in the anteroflexid, between the anterocristid (anterolophid sensu Candela 2002) and the second cristid (metalophulid II sensu Candela 2002), and mesially to the metaconid (Figure 17). Other extinct taxa such as Shapajamys labocensis (Boivin et al. 2018), Eobranisamys romeropittmanae (Frailey and Campbell 2004), Branisamys luribayensis (Hartenberger 1975; Patterson and Wood 1982; Candela 2002), Incamys bolivianus (e.g., MNHN-Bol 008499), Drytomomys typicus (Candela and Nasif 2006) and Luantus propheticus (Kramarz 2006b), seem to have developed this pattern (see coding of the character 320 in Boivin 2017 and Boivin et al. submitted). Nevertheless, the recognition of the cuspids (protoconid and metaconid) and anterior cristids (posterior arm of the 
protoconid, mesolophid, neomesolophid, metaconid cristid, and neolophid) is often ambiguous on dp4s of erethizontoids. Moreover, some representatives of this superfamily would develop another type of neolophid located not mesially to the metaconid but distally to this cuspid (see coding of the character 318 in Boivin 2017 and Boivin et al. submitted). For instance, the specimen MACN A 4160, attributed to Steiromys detentus, shows a short neocristulid stemming from the lingual edge in the anteroflexid. This neocristulid, situated between the anterocristid and the second cristid, is distally located to the metaconid (Figure 17). The oblique 'second cristid' would correspond to the posterior arm of the protoconid, which is connected to a neomesolophid (i.e., a combination of branches forming the second and third cristids of the pentalophodont scheme, respectively). The MACN 52-176 dp4 of Hypsosteiromys presents a similar cristulid to that observed in MACN A 4160, which is positioned distally to the metaconid.

\section{Conclusions}

The exhaustive analysis of the material from Contamana and Tarapoto/Shapaja, and its comparisons with other hystricognath specimens (fossil and modern New and Old World hystricognaths) further our understanding regarding the homology and the evolutionary patterns of the dentary structures in caviomorphs. Our analytical results (1) support and/or allow to generalize some hypotheses formerly proposed about the occlusal morphology of caviomorph cheek teeth and associated evolutionary transformations (e.g., Vucetich and Verzi 1994; Candela 1999, 2002; Candela and Rasia 2012), and (2) propose new hypotheses of dental homologies and evolutionary trends. In caviomorphs, the third crest of the upper teeth is highly variable and would correspond either to a mesoloph (stemming from the mesostyle), or a mesolophule (originating from the mesial extremity of the anterior arm of the hypocone [i.e., former position 
of the ancestral metaconule]), or a combination of both. In most early and subsequent caviomorphs, the transformation from a pentalophodont pattern to a tetralophodont pattern would be explained by the reduction/loss of the metaloph or its merging with the posteroloph, and the tranformation from a tetralophodont pattern to a trilophodont pattern, by the reduction/loss of the the third crest or its merging with the posteroloph. A direct transformation from a pentalophodont pattern to a trilophodont pattern is also observed. On the mesial part of lower teeth, the development of distinct cristids can be recognized, depending primarily on their connections with other structures and secondarily on their position and orientation: metalophulid I (for $\mathrm{p} 4 \mathrm{~s}$ and lower molars)/anterocristid (for $\mathrm{dp} 4 \mathrm{~s}$ ), posterior arm of the protoconid, metaconid cristid, neomesolophid, mesolophid, and different types of neolophids. Given our observations on ancient fossil specimens, the ancestral pattern of lower molars in caviomorphs was likely tetralophodont, and that of dp4s pentalophodont. However, schemes with five and four (even three) transverse cristids can not be ruled out for the two loci, respectively. The trilophodont pattern of lower molars was mostly secondarily achieved by the loss of the second cristid, a loss which seems to have occurred distinctly, iteratively and at different times in several superfamilies (notably chinchilloids $v s$ octodontoids) and genera. Caviomorphs show a significant disparity of occlusal patterns on their cheek teeth throughout their evolutionary history, which is the result of a complex evolution, involving many comtemporaneous and non-comtemporaneous convergences and parallelisms for each locus. It would be now interesting to assess the correlative effects of the modifications in the number of loph(-id)s and cusp(id)s with other characters (dental, but also mandibular and cranial), to determine if they could be key innovations for this rodent group, and then to explore the modalities of their appearance/selection. 


\section{Acknowledgements}

We especially thank members and supporters of the international team who contributed to the discovery and exploitation of the caviomorph-bearing localities from Peruvian Amazonia. F. Catzeflis (ISE-M, France), S. Jiquel (ISE-M), B. Marandat (ISE-M), C. Argot (MNHN, France), G. Billet (MNHN), V. Nicolas (MNHN), A. Verguin (MNHN), C. Chacaltana (INGEMMET, Peru), L.M. Tejada-Medina (INGEMMET), A. Kramarz (MACN, Argentina), M. Reguero (MLP, Argentina), I. Olivares (MLP) and B. Mamani Quispe (MNHN-Bol, Bolivia) kindly granted access to the osteological collections under their care. Many thanks to F. Pujos (IANIGLA, Argentina) for his help and long standing investment in our collaboration with the MNHN-Bol; R. Andrade Flores (MNHN-Bol) and C. Robinet (MLP) for their precious help during our journey at the MNHN-Bol; L. Defend (ISE-M) for the inventory and conditioning of the UM collections of Salla rodents. We thank L. Hautier (ISE-M), P.-H. Fabre (ISE-M), A. Candela (MLP), and C. Robinet for providing us the photographs of several collection specimens. Many thanks to A.-L. Charruault (ISE-M), S. Jiquel, S. Unal (ISE-M), P. Coster (UK, USA), H. Sallam (Mansoura University, Egypt) and M.G. Vucetich (MLP) who kindly made and/or provided us casts of fossil rodents. We are particularly indebted to M. Arnal (MLP, Argentina), A. Candela, A.G. Kramarz, M.E. Pérez (MPEF, Argentina) and M.G. Vucetich for fruitfull discussion on rodent dental homologies. We are particularly grateful to P.-O. Antoine (ISE-M), V. Barriel (MNHN), A. Candela, A. Kramarz, E. Seiffert (USC, USA) for their well-appreciated reading of this work, and their sensible remarks and advices. Lastly, we also thank the Editor in Chief of Historical Biology (G. Dyke, UD, USA) and the two anonymous revierwers, who provided formal reviews of this manuscript that enhanced the final version. This is ISEM publication 2018-152. 


\section{Disclosure statement}

No potential conflict of interest was reported by the authors.

\section{Funding}

Parts of this work were supported by the L.S.B. Leakey Foundation; the National Geographic Society; the LabEx CEBA under Grant "Agence Nationale de la Recherche" - "Investissements d'Avenir" (ANR-10-LABX-0025-01; SOURCE and NEOTROPHYL projects); by the COOPINTEER CNRS/CONICET program; and the ECOS-SUD/FONCyT program.

\section{ORCID}

Myriam Boivin ～http://orcid.org/0000-0002-5240-9460

Laurent Marivaux $\quad$ http://orcid.org/0000-0002-2882-0874

\section{References}

Ameghino F. 1887. Enumeración sistematica de las especies de mamíferos fósiles coleccionados por Carlos Ameghino en los terrenos eocenos de Patagonia austral y depositados en el museo de La Plata. Bol Mus La Plata. 1:1-26.

Antoine P-O, Marivaux L, Croft DA, Billet G, Ganerød M, Jaramillo C, Martin T, Orliac MJ, Tejada-Lara J, Altamirano AJ, Duranthon F, Fanjat G, Rousse S, Salas-Gismondi R. 2012. Middle Eocene rodents from Peruvian Amazonia reveal the pattern and timing of caviomorph origins and biogeography. Proc. R. Soc. B. 279:1319-1326. 


\begin{abstract}
Antoine P-O, Abello M, Adnet S, Altamirano Sierra AJ, Baby P, Billet G, Boivin M, Calderón Y, Candela A, Chabain J, Corfu F, Croft DA, Ganerød M, Jaramillo C, Klaus S, Marivaux L, Navarrete RE, Orliac MJ, Parra F, Pérez ME, Pujos F, Rage J-C, Ravel A, Robinet C, Roddaz M, Tejada-Lara JV, Vélez-Juarbe J, Wesselingh FP, Salas-Gismondi R. 2016. A 60-million-year Cenozoic history of western Amazonian ecosystems in Contamana, eastern Peru. Gondwana Res. $31: 30-59$.
\end{abstract}

Arnal M. 2012. Sistemática, filogenia e historia evolutiva de roedores Octodontoidea (Caviomorpha, Hystricognathi) del Oligoceno tardío-Mioceno medio vinculados al origen de la familia Octodontidae. Unpublished PhD thesis, Universidad Nacional de La Plata.

Arnal M, Vucetich MG. 2011. First record of supernumerary teeth in South American fossil rodents. J Vert Paleontol. 31:925-927.

Arnal M, Vucetich MG. 2015. Revision of the fossil rodent Acaremys Ameghino, 1887 (Hystricognathi, Octodontoidea, Acaremyidae) from the Miocene of Patagonia (Argentina) and the description of a new acaremyid. Hist Biol. 27:42-59.

Arnal M, Kramarz AG, Vucetich MG, Vieytes EC. 2014. A new early Miocene octodontoid rodent (Hystricognathi, Caviomorpha) from Patagonia (Argentina) and a reassessment of the early evolution of Octodontoidea. J Vert Paleontol. 34:397-406.

Barbière F, Marivaux L. 2015. Phylogeny and evolutionary history of hystricognathous rodents from the Old World during the Tertiary: new insights into the emergence of modern 'phiomorph' families. In: Cox P, Hautier L, editors. Evolution of the Rodents: Advances in Phylogeny, Functional Morphology and Development. Cambridge: Cambridge University Press; p. 87-1120. 

Black CC, Wood AE. 1956. Variation and tooth-replacement in a Miocene mylagaulid rodent. J Paleontol. 672-684.

Boivin M. 2017. Rongeurs paléogènes d'Amazonie péruvienne : anatomie, systématique, phylogénie et paléobiogéographie Unpublished $\mathrm{PhD}$ thesis, Montpellier.

Boivin M, Marivaux L, Orliac MJ, Pujos F, Salas-Gismondi R, Tejada-Lara JV, Antoine P-O. 2017a. Late middle Eocene caviomorph rodents from Contamana, Peruvian Amazonia. Palaeontol Electron. 20.1.19A:1-50.

Boivin M, Marivaux L, Candela AM, Orliac MJ, Pujos F, Salas-Gismondi R, Tejada-Lara JV, Antoine P-O. 2017b. Late Oligocene caviomorph rodents from Contamana, Peruvian Amazonia. Pap Palaeontol. 3:69-109.

Boivin M, Marivaux L, Pujos F, Salas-Gismondi R, Tejada-Lara JV, Varas-Malca R, Antoine P-O. 2018. Early Oligocene caviomorph rodents from Shapaja, Peruvian Amazonia. Palaeontogr Abt A. 311. DOI: $10.1127 /$ pala/2018/0075.

Boivin M, Marivaux L, Antoine P-O. L'apport du registre paléogène d'Amazonie sur la diversification initiale des Caviomorpha (Hystricognathi, Rodentia) : implications phylogénétiques, macroévolutives et paléobiogéographiques. Geodiversitas. (submitted) Bryant JD, McKenna MC. 1995. Cranial anatomy and phylogenetic position of Tsaganomys altaicus (Mammalia; Rodentia) from the Hsanda Gol formarion (Oligocene), Mongolia. Am Mus Novit. (3156): 1-42. 
Butler PM. 1985. Homologies of molar cusps and crests, and their bearing on assessments of rodent phylogeny. In: Luckett WP, Hartenberger J-L, editors. Evolutionary Relationships among Rodents, a Multidisciplinary Analysis. New York: Springer US; p. 381-401.

Candela AM. 1999. The evolution of the molar pattern of the Erethizontidae (Rodentia, Hystricognathi) and the validity of Parasteiromys Ameghino, 1904. Palaeovertebrata 28:53-73.

Candela AM. 2000. Los Erethizontidae (Rodentia, Hystricognathi) fósiles de Argentina. Sistemática e historia evolutiva y biogeográfica. Unpublished $\mathrm{PhD}$ thesis, Universidad Nacional de La Plata.

Candela AM. 2002. Lower deciduous tooth homologies in Erethizontidae [Rodentia, Hystricognathi]: evolutionary significance. Acta Palaeontol Pol. 47:717-723.

Candela AM. 2003. A new porcupine (Rodentia, Erethizontidae) from the Early and Middle Miocene of Patagonia. Ameghiniana. 40:483-494.

Candela AM. 2004. A New Giant Porcupine (Rodentia, Erethizontidae) from the Late Miocene of Argentina. J Vert Paleontol. 24:732-741.

Candela AM. 2015. Analyzing the impact of conflictive dental characters on the phylogeny of octodontoid rodents. Acta Palaeontol Pol. 61:455-468.

Candela AM, Nasif NL. 2006. Systematics and biogeographic significance of Drytomomys typicus (Scalabrini in Ameghino, 1889) nov. comb., a Miocene Dinomyidae (Rodentia, Hystricognathi) from Northeast of Argentina. Neues Jahrb Geol Paläontol. 3:165-181.

Candela AM, Rasia LL. 2012. Tooth morphology of Echimyidae (Rodentia, Caviomorpha): homology assessments, fossils, and evolution. Zool J Linn Soc. 164:451-480. 
Carvalho GA, Salles LO. 2004. Relationships among extant and fossil echimyids (Rodentia:

Hystricognathi). Zool J Linn Soc. 142:445-477.

Coster P, Benammi M, Salem M, Bilal AA, Chaimanee Y, Valentin X, Brunet M, Jaeger J-J. 2012. New hystricognathous rodents from the Early Oligocene of central Libya (Zallah Oasis, Sahara Desert): systematic, phylogenetic, and biochronologic implications. Ann Carnegie Mus. 80:239259.

Dawson MR. 1977. Late Eocene rodent radiation: North America, Europe and Asia. Géobios. 1 Mémoire spécial:195-209.

Dawson MR, Li C-K, Qi T. 1984. Eocene ctenodactyloid rodents (Mammalia) of eastern central Asia. Ann Carnegie Mus. 9 Special Publication:138-150.

Fabre P-H, Hautier L, Dimitrov D, Douzery EJ. 2012. A glimpse on the pattern of rodent diversification: a phylogenetic approach. BMC Evol Biol. 12:88.

Fields RW. 1957. Hystricomorph rodents from the Late Miocene of Colombia, South America. Univ Calif publ geol. 32:273-404.

Flynn JJ, Jacobs LL, Cheema IU. 1986. Baluchimyinae, a new ctenodactyloid rodent subfamily from the Miocene of Baluchistan. Am Mus Novit. 2841:1-58.

Frailey CD, Campbell KE. 2004. Paleogene rodents from Amazonian Peru: the Santa Rosa local fauna. In: Campbell KE, editor. The Paleogene Mammalian Fauna of Santa Rosa, Amazonian Peru. Natural History Museum of Los Angeles County, Science Series 40; p. 71-130.

George W. 1993. The strange rodents of Africa and South America. In George W, Lavocat R, editors. The Africa-South America Connection. Oxford: Clarendon Press; p. 119-141. 
Jaeger J-J. 1989. L'évolution de la pentalophodontie chez les rongeurs Caviomorphes (Mammalia, Rodentia). Geobios. 22:235-244.

Jaeger J-J, Denys C, Coiffait B. 1985. New Phiomorpha and Anomaluridae from the late Eocene of North-West Africa: phylogenetic implications. In: Luckett WP, Hartenberger J-L, editors. Evolutionary Relationships among Rodents, a Multidisciplinary Analysis. New York: Springer US; p. 567-588.

Jaeger J-J, Marivaux L, Salem M, Bilal AA, Chaimanee Y, Marandat B, Valentin X, Duringer P, Schuster M, Benammi M, Métais E, Brunet M. 2010. New rodent assemblages from the Eocene Dur at-Talah escarpment (Sahara of Central Libya): systematic, biochronologic and paleobiogeographic implications. Zool J Linn Soc. 160:195-213.

Luckett WP, Hartenberger J-L. 1993. Monophyly or polyphyly of the order Rodentia: possible conflict between morphological and molecular interpretations. J Mamm Evol. 1:127-147.

Hartenberger J-L. 1975. Nouvelles découvertes de rongeurs dans le Déseadien (Oligocène inférieur) de Salla Luribay (Bolivie). C R Acad Sci. 280:427-430.

Hartenberger J-L, Megard F, Sigé B. 1984. Faunules à rongeurs de l'Oligocène inférieur à Lircay (Andes du Pérou Central): datation d'un épisode karstique; intérêt paléobiogéographique des remplissages tertiaires en Amérique du Sud. C R Acad Sci Ser. 2. 299:565-568.

Hoffstetter R. 1971. Le peuplement mammalien de l'Amérique du Sud. Rôle des continents austraux comme centres d'origine, de diversification et de dispersion pour certain groupes mammaliens. An Acad Bras Ciênc. 43 Suppl:125-143. 
Hoffstetter R. 1972. Origine et dispersion des Rongeurs Hystricognathes. C R Acad Sci. 274:2867-2870.

Hoffstetter R. 1975. El origen de los Caviomorpha y el problema de los Hystricognathi (Rodentia). Actas del Primer Congreso Argentino de Paleontologia y Bioestratigraphia, Tucumán, Agosto 1974, 2:505-528.

Hoffstetter R. 1976. Rongeurs caviomorphes de l'Oligocène de Bolivie. Palaeovertebrata 7:1-14.

Hoffstetter R, Lavocat R. 1970. Découverte dans le Déséadien de Bolivie des genres pentalophodontes appuyant les affinités africaines des rongeurs caviomorphes. C R Acad Sci. $271: 172-175$.

Huchon D, Douzery EJ. 2001. From the OldWorld to the NewWorld: a molecular chronicle of the phylogeny and biogeography of hystricognath rodents. Mol Phylogenetics Evol. 20:238-251

Huchon D, Catzeflis FM, Douzery EJP. 2000. Variance of molecular datings, evolution of rodents, and the phylogenetic affinities between Ctenodactylidae and Hystricognathi. Proc R Soc Lond B Biol Sci. 267:393-402

Huchon D, Chevret P, Jordan U, Kilpatrick CW, Ranwez V, Jenkins PD, Brosius J, Schmitz J. 2007. Multiple molecular evidences for a living mammalian fossil. Proc Natl Acad Sci USA. 104:7495-7499

Huchon D, Madsen O, Sibbald MJ, Ament K, Stanhope MJ, Catzeflis F, Jong WW de, Douzery EJ. 2002. Rodent phylogeny and a timescale for the evolution of Glires: evidence from an extensive taxon sampling using three nuclear genes. Mol Phylogenetics Evol. 19:1053-1065 
Kerber L, Negri FR, Ribeiro AM, Nasif N, Souza-Filho JP, Ferigolo J. 2017. Tropical fossil caviomorph rodents from the southwestern Brazilian Amazonia in the context of the South American faunas: systematics, biochronology, and paleobiogeography. J Mamm Evol. 24:57-70.

Kramarz AG. 1998. Un nuevo dasyproctidae (Rodentia, Caviomorpha) del Mioceno inferior de Patagonia. Ameghiniana. 35:181-192.

Kramarz AG. 2001a. Registro de Eoviscaccia (Rodentia, Chinchillidae) en estratos colhuehuapenses de Patagonia, Argentina. Ameghiniana. 38:237-242.

Kramarz AG. 2001b. Un nuevo roedor Adelphomyinae (Hystricognathi, Echimyidae) del Mioceno Medio-Inferior de Patagonia, Argentina. Ameghiniana. 38:163-168.

Kramarz AG. 2002. Roedores chinchilloideos (Hystricognathi) de la Formación Pinturas, Mioceno temprano-medio de la provincia de Santa Cruz, Argentina. Rev Mus Argent Cienc Nat. 4 nueva serie: $167-180$.

Kramarz AG. 2004. Octodontoids and erethizontoids (Rodentia, Hystricognathi) from the Pinturas Formation, Early-Middle Miocene of Patagonia, Argentina. Ameghiniana. 41:199-216.

Kramarz AG. 2006a. Neoreomys and Scleromys (Rodentia, Hystricognathi) from the Pinturas Formation, late Early Miocene of Patagonia, Argentina. Rev Mus Argent Cienc Nat. 8:53-62. Kramarz AG. 2006b. Eocardiids (Rodentia, Hystricognathi) from the Pinturas Formation, late Early Miocene of Patagonia, Argentina. J Vert Paleontol. 26:770-778.

Kramarz AG, Vucetich MG, Arnal M. 2013. A new Early Miocene chinchilloid hystricognath rodent; an approach to the understanding of the early chinchillid dental evolution. J Mamm Evol. 20:249-261. 
Korth WW. 1984. Earliest Tertiary evolution and radiation of rodents in North America. Bull Carnegie Mus Nat Hist. 24:1-71.

Korth WW. 1994. The Tertiary record of rodents in North America. New York: Springer Science and Business Media.

Kumar K, Srivastava R, Sahni A. 1997. Middle Eocene rodents from the Subathu Group. Northwest Himalaya. Palaeovertebrata. 26:83-128.

Lavocat R. 1967. Les microfaunas du Néogène d'Afrique orientale et leurs rapports avec celles de la région paléarctique. In Bishop WW, Clark JD, editors. Background to Evolution in Africa. Chicago: University of Chicago Press; p. 57-72.

Lavocat R. 1969. La systématique des rongeurs hystricomorphes et la dérive des continents. C R Acad Sci. 269:1496-1497.

Lavocat R. 1971. Affinités systématiques des caviomorphes et des phiomorphes et origine africaine des caviomorphes. An Acad brasil Cienc. 41 Supl:515-622.

Lavocat R. 1973. Les rongeurs du Miocène d'Afrique orientale. 1. Miocène inférieur. Mémoires et Travaux E.P.H.E. de 1'Institut de Montpellier.

Lavocat R. 1974a. The interrelationships between the African and South American rodents and their bearing on the problem of the origin of South American monkeys. J Hum Evol. 3:323-326.

Lavocat R. 1974b. What is a Hystricomorph? In: Rowlands IW, Weir BJ, editors. The Biology of Hystricomorph Rodents. Symposium of the Zoological society of London 34:7-20, 55-60.

Lavocat R. 1976. Rongeurs caviomorphes de l'Oligocène de Bolivie. Rongeurs du bassin déséadien de Salla. Palaeovertebrata. 7:15-90. 


\begin{abstract}
Lavocat R. 1977a. Sur l'origine des faunes sud-américaines de mammifères du Mésozoïque terminal et du Cénozoïque ancien. C R Acad Sci. 285: 1423-1426.
\end{abstract}

Lavocat R. 1977b. Les relations faunistiques Afrique-Amérique. Colloque de Montpellier (12-16 Sept.). Mémoires et Travaux E.P.H.E. de 1'Institut de Montpellier 1:169-179.

Lavocat R. 1980. The implications of rodent paleontology and biogeography to the geographical sources and origin of the platyrrhine primates. In: Ciochon RL \& Chiarelli AB, editors. Evolutionary Biology of the New World Monkeys and Continental Drift. New York: Springer US; p. 93-102.

Marivaux L. 2000. Les rongeurs de l'Oligocène des Collines Bugti (Balouchistan, Pakistan) : nouvelles données sur la phylogénie des rongeurs paléogènes, implications biochronologiques et paléobiogéographiques. Unpublished PhD thesis, Université de Montpellier, France.

Marivaux L, Welcomme J-L. 2003. New diatomyid and baluchimyine rodents from the Oligocene of Pakistan (Bugti Hills, Balochistan): systematic and paleobiogeographic implications. J Vert Paleontol. 23:420-434.

Marivaux L, Benammi M, Ducrocq S, Jaeger J-J, Chaimanee Y. 2000. A new baluchimyine rodent from the Late Eocene of the Krabi Basin (Thailand): palaeobiogeographic and biochronologic implications. C R Acad Sci. 331:427-433.

Marivaux L, Welcomme J-L, Vianey-Liaud M, Jaeger J-J. 2002. The role of Asia in the origin and diversification of hystricognathous rodents. Zool Scr. 31:225-239.

Marivaux L, Vianey-Liaud M, Jaeger J-J. 2004. High-level phylogeny of early Tertiary rodents: dental evidence. Zool J Linn Soc. 142:105-134. 
Marivaux L, Essid EM, Marzougui W, Ammar HK, Adnet S, Marandat B, Merzeraud G, Tabuce

R, Vianey-Liaud M. 2014. A new and primitive species of Protophiomys (Rodentia, Hystricognathi) from the late Middle Eocene of Djebel el Kébar, Central Tunisia.

Palaeovertebrata. 38:1-17.

Marivaux L, Adnet S, Benammi M, Tabuce R, Yans J, Benammi M. 2017a. Earliest Oligocene hystricognathous rodents from the Atlantic margin of northwestern Saharan Africa (Dakhla, Morocco): systematic, paleobiogeographical and paleoenvironmental implications. J Vert Paleontol. 37:1-22.

Marivaux L, Adnet S, Benammi M, Tabuce R, Benammi M. 2017b. Anomaluroid rodents from the earliest Oligocene of Dakhla, Morocco, reveal the long-lived and morphologically conservative pattern of the Anomaluridae and Nonanomaluridae during the Tertiary in Africa. J Syst Palaeontol. 15:539-569.

Meng J. 1990. The auditory region of Reithroparamys delicatissimus (Mammalia, Rodentia) and its systematic implications. Am Mus Novit. 2972:1-35.

Meng J, Wyss AR. 2001. The morphology of Tribosphenomys (Rodentiaformes, Mammalia): phylogenetic implications for basal Glires. J Mamm Evol. 8:1-71.

Montgelard C, Arnal V, Forty E, Matthee CA. 2008. Suprafamilial relationships among Rodentia and the phylogenetic effect of removing fast-evolving nucleotides in mitochondrial, exon and intron fragments. BMC Evol Biol. 8:1-16.

Nedbal MA, Honeycutt RL, Schilitter DA. 1996. Higher-level systematics of rodents (Mammalia, Rodentia): evidence from the mitochondrial 12S rRNA gene. J Mamm Evol. 3:201-237. 
Osborn HF. 1907. Evolution of mammalian molar teeth to and from the triangular type including collected and revised research on trituberculity and new sections on the forms and homologies of the molar teeth in different orders of mammals. Biol Studies Addr. 1:1-245

Patterson B, Pascual R. 1968. New echimyid rodents from the Oligocene of Patagonia, and a synopsis of the family. Breviora. 301:1-14.

Patterson B, Wood AE. 1982. Rodents from the Deseadan Oligocene of Bolivia and the relationships of the Caviomorpha. Bull Mus Comp Zool. 149:371-543.

Pérez ME, Arnal M, Boivin M, Vucetich MG, Candela A, Busker F, Mamani Quispe B. New caviomorph rodents from the Late Oligocene of Salla, Bolivia: taxonomic, chronological, and biogeographic implications in the Deseadan faunas of South America. J Syst Palaeontol. DOI: 10.1080/14772019.2018.1471622.

Pinna MCC de. 1991. Concepts and tests of homology in the cladistic paradigm. Cladistics. $7: 367-394$.

Rasia LL, Candela A. M. 2017. Reappraisal of the giant caviomorph rodent Phoberomys burmeisteri (Ameghino, 1886) from the Late Miocene of northeastern Argentina, and the phylogeny and diversity of Neoepiblemidae. Hist Biol. DOI: 10.1080/08912963.2017.1294168.

Remane A. 1952. Die Grundlagen Des Natürlichen Systems, der Vergleichenden Anatomie und der Phylogenetic. Leipzig: Akademische Verlagsgesellschaft Geest and Portig K-G.

Ribeiro AM, Madden RH, Negri FR, Kerber L, Hsiou AS, Rodrigues KA. 2013. Mamíferos fósiles y biocronología en el suroeste de la Amazonia, Brasil. Asociación Paleontológica Argentina. 14 Publicación Especial:207-221. 
Rieppel O. 1988. Fundamentals of comparative biology. Basel: Birkhäuser Verlag.

Rieppel O. 1994. Homology, topology, and typology: the history of modern debates. In Hall BK editor. Homology: the hierarchical basis of comparative biology. NewYork: Academic Press; p. 63-100.

Rieppel O, Kearney M. 2002. Similarity. Biol J Linn Soc. 75:59-82.

Sallam HM, Seiffert ER. 2016. New phiomorph rodents from the latest Eocene of Egypt, and the impact of Bayesian "clock"-based phylogenetic methods on estimates of basal hystricognath relationships and biochronology. PeerJ. 4, e1717.

Sallam HM, Seiffert ER, Steiper ME, Simons EL. 2009. Fossil and molecular evidence constrain scenarios for the early evolutionary and biogeographic history of hystricognathous rodents. Proc Natl Acad Sci USA. 106:16722-16727.

Sallam HM, Seiffert ER, Simons EL. 2011. Craniodental morphology and systematics of a new family of hystricognathous rodents (Gaudeamuridae) from the Late Eocene and Early Oligocene of Egypt. PLoS One. 6, e16525.

Sallam HM, Seiffert ER, Simons EL. 2012. A basal phiomorph (Rodentia, Hystricognathi) from the Late Eocene of the Fayum Depression, Egypt. Swiss J Palaeontol. 131:283-301.

Schaub S. 1953. Remarks on the distribution and classification of the Hystricomorpha. Verh Naturforsch Ges Basel. 64:389-400.

Simpson GG. 1936. Studies of the earliest mammalian dentitions. Dental Cosmos. 78:791-800, 940-953.

Stirton RA. 1935. A review of the Tertiary beavers. Univ Calif Publ Geol. 23:391-458. 
Verzi DH, Olivares AI, Morgan CC. 2014. Phylogeny and evolutionary patterns of South American octodontoid rodents. Acta Palaeontol Pol. 59:757-769.

Verzi DH, Olivares AI, Morgan CC, Álvarez A. 2016. Contrasting phylogenetic and diversity patterns in octodontoid rodents and a new definition of the family Abrocomidae. J Mamm Evol. 23:93-115.

Verzi DH, Olivares AI, Morgan CC. 2017. Systematics and evolutionary significance of the small Abrocomidae from the Early Miocene of southern South America. Hist Biol. 29:411-422.

Verzi DH, Olivares AI, Morgan CC. 2018. Morphology of the lower deciduous premolars of South American hystricomorph rodents and age of the Octodontoidea. Hist Biol. DOI:

$10.1080 / 08912963.2018 .1427089$

Vucetich MG, Bond M. 1984. Un nuevo Octodontoidea (Rodentia, Caviomorpha) del Oligoceno tardío de la provincia de Chubut (Argentina). Ameghiniana. 21:105-114.

Vucetich MG, Kramarz AG. 2003. New Miocene rodents of Patagonia (Argentina) and their bearing in the early radiation of the octodontoids (Hystricognathi). J Vert Paleontol. 23:435-444.

Vucetich MG, Verzi DH. 1991. Un nuevo Echimyidae (Rodentia, Hystricognathi) de la edad Colhuehuapense de Patagonia y consideraciones sobre la sistemática de la familia. Ameghiniana. 28:67-74.

Vucetich MG, Verzi DH. 1994. Las homologías en los diseños oclusales de los roedores Caviomorpha: un modelo alternativo. Mastozool neotrop. 1:61-72.

Vucetich MG, Verzi DH. 1996. A peculiar octodontoid (Rodentia, Caviomorpha) with terraced molars from the Lower Miocene of Patagonia (Argentina). J Vert Paleontol. 16:297-302. 
Vucetich MG, Vieytes EC. 2006. A Middle Miocene primitive octodontoid rodent and its bearing on the early evolutionary history of the Octodontoidea. Palaeontogr Abt A. 27:81-91.

Vucetich MG, Verzi DH, Dozo MT. 1992. El ‘status’ sistemático de Gaimanomys alwinea (Rodentia, Caviomorpha, Echimyidae). Ameghiniana. 29:85-86.

Vucetich MG, Souza Cunha FL de, Alvarenga HMF de. 1993. Un Roedor Caviomorpha de la Formación Tremembé (Cuenca de Taubaté), Estado de Sao Paulo, Brasil. An Acad Bras Ciênc. $65: 247-251$.

Vucetich MG, Vieytes EC, Pérez ME, Carlini AA. 2010a. The rodents from La Cantera and the early evolution of caviomorphs in South America. In: Madden RH, Carlini AA, Vucetich MG, Kay RF, editors. The Paleontology of Gran Barranca, Evolution and Environmental Change through the Middle Cenozoic of Patagonia. Cambridge: Cambridge University Press; p. 189-201. Vucetich MG, Kramarz AG, Candela AM. 2010b. Colhuehuapian rodents from Gran Barranca and other Patagonian localities: the state of the art. In: Madden RH, Carlini AA, Vucetich MG, Kay RF, editors. The Paleontology of Gran Barranca, Evolution and Environmental Change through the Middle Cenozoic of Patagonia. Cambridge: Cambridge University Press; p. 206-219. Vucetich MG, Dozo MT, Arnal M, Pérez ME. 2015. New rodents (Mammalia) from the Late Oligocene of Cabeza Blanca (Chubut) and the first rodent radiation in Patagonia. Hist Biol. $27: 236-257$.

Walton AH. 1997. Rodents. In: Kay RF, Madden RH, Cifelli RL, Flynn JJ, editors. Vertebrate paleontology in the Neotropics. The Miocene Fauna of La Venta, Colombia. Washington and London: Smithsonian Institution Press; p. 392-409. 
Wang BY. 1997. The mid-Tertiary Ctenodactylidae (Rodentia, Mammalia) of eastern and central Asia. Bull Am Mus Nat Hist. 234:1-88.

Wood AE. 1949. A new Oligocene rodent genus from Patagonia. Am Mus Novit. (1435):1-54.

Wood AE. 1955. A revised classification of the rodents. J Mammal. 36:165-187.

Wood AE. 1959. Eocene radiation and phylogeny of the rodents. Evolution. 13:354-361.

Wood AE. 1962. The early Tertiary rodents of the family Paramyidae. Trans Am Philos Soc. 52:1-261.

Wood AE. 1965. Grades and clades among rodents. Evolution. 19:115-130.

Wood AE. 1968. Early Cenozoic mammalian faunas, Fayum Province, Egypt, Part II: the African Oligocene Rodentia. Peabody Mus Nat Hist. 28:23-105.

Wood AE. 1972. An Eocene hystricognathous rodent from Texas: its significance in interpretations of continental drift. Science. 175:1250-1251.

Wood AE. 1973. Eocene rodents, Pruett Formation, southwest Texas: their pertinence to the origin of the South American Caviomorpha. Pearce-Sellards Series 20: 1-41.

Wood AE. 1974. The evolution of the Old World and New World hystricomorphs. Symposia of the Zoological Society of London 34:21-60.

Wood AE. 1975. The problem of the hystricognathous rodents. University of Michigan Papers on Paleontology. 12:75-80. 
Wood AE. 1980. The origin of the caviomorph rodents from a source in Middle America. In:

Ciochon RL, Chiarelli AB, editors. Evolutionary Biology of the New World Monkeys and Continental Drift. New York: Springer US; p. 79-91.

Wood AE. 1983. The radiation of the order Rodentia in the southern continents: the dates, numbers and sources of the invasions. Z Geol Wiss. 19:381-394.

Wood AE. 1984. Hystricognathy in the North American Oligocene rodent Cylindrodon and the origin of the Caviomorpha. Ann Carnegie Mus Nat Hist. 9 Special Publication:151-160.

Wood AE. 1985a. The relationships, origin and dispersal of the hystricognathous rodents. In: Luckett WP, Hartenberger J-L, editors. Evolutionary Relationships among Rodents, a Multidisciplinary Analysis. New York: Springer US; p. 475-513.

Wood AE. 1985b. Northern waif primates and rodents. In: Luckett WP, Hartenberger J-L, editors. Evolutionary Relationships among Rodents, a Multidisciplinary Analysis. New York: Springer US; p. 267-282.

Wood AE. 1983. The radiation of the Order Rodentia in the southern continents: the dates, numbers and sources of the invasions. In: Heinrich, W-D, editor. Wirbeltier-Evolution und Faunenwandel in Känozoicum. Schriftenr Geol Wiss Berlin. 19/20:381-394.

Wood AE, Wilson RW. 1936. A suggested nomenclature for the cusps of the cheek teeth of rodents. J Paleontol. 10:388-391.

Wood AE, Patterson B. 1959. The rodents of the Deseadan Oligocene of Patagonia and the beginnings of South American rodent evolution. Bull Mus Comp Zool. 120:281-428. 


\section{Figure captions}

Figure 1. Nomenclature of upper teeth used in this study. (A) occlusal view of upper molar (based of two different specimens); (B) occlusal view of DP4; (C) occlusal view of P4; (D) lingual view of upper tooth; (E) labial view of upper tooth. The nomenclature is based on the dental terminology of different authors (see text) and on the observations carried out in the context of this study. 1 , paracone; 2 , protocone; 3 , metacone; 4 , hypocone; 5 , parastyle; 6 , mesostyle; 7, anteroloph; 8, anterior arm of the protocone; 9, lingual protoloph (= posterior arm of the protocone); 10, posterior outgrowth of the protocone; 11, protoloph (= labial protoloph); 12, mure; 13, third transverse crest (= central transverse crest); 14, mesolophule; 15, mesoloph; 16, anterior arm of the hypocone; 17, metaloph; 18, posteroloph; 19, paraflexus; 20, parastria; 21, hypoflexus/hypofossette; 22, confluence of the paraflexus with the hypoflexus; 23, hypostria; 24, mesial mesoflexus/mesofossette; 25, mesostria; 26, distal mesoflexus/mesofossette; 27, metastria; 28, confluence of the distal mesoflexus with the metaflexus (i.e., posteroflexus); 29, posteroflexus. Abbreviations: ant., anterior; ling., lingual.

Figure 2. Nomenclature of lower teeth used in this study. (A) occlusal view of lower molar (based of two different specimens); (B) occlusal view of dp4; (C) occlusal view of p4; (D) labial view of lower tooth; (E) lingual view of lower tooth. The nomenclature is based on the dental terminology of different authors (see text) and on the observations carried out in the context of this study. 1, protoconid; 2, metaconid; 3 , mesoconid; 4, entoconid; 5, hypoconid; 6 , mesostylid; 7, metalophulid I; 8, anterocristid; 9, posterior arm of the metaconid; 10, posterior arm of the 
protoconid; 11, neomesolophid; 12, second transverse cristid; 13, mesolophid; 14, rest of the mesolophid?; 15, ectolophid; 16, mesial ectolophid; 17, distal ectolophid; 18, hypolophid; 19, anterior arm of the entoconid; 20, posterior arm of the entoconid; 21, anterior arm of the hypoconid; 22, posterior arm of the hypoconid; 23 , anterior outgrowth of the hypoconid; 24 , posterolophid; 25, anteroflexid/anterofossettid; 26, anterostriid; 27, mesoflexid; 28, mesial mesoflexid; 29, distal mesoflexid; 30, mesostriid; 31, confluence of the anteroflexid with the mesoflexid; 32, hypoflexid; 33, hypostriid; 34, metaflexid; 35, metastriid; 36, confluence of the hypoflexid with the metaflexid. Abbreviations: ant., anterior; ling., lingual.

Figure 3. The hypotheses regarding the homology of structures on upper molars. (A) Wood and Patterson (1959), Patterson and Wood (1982) (caviomorphs); (B) Hoffstetter and Lavocat (1970), Lavocat (1976) (caviomorphs); (C) Bryant and McKenna (1995; 'phiomorphs' and caviomorphs); (D) Candela (1999; erethizontoids); (E) Marivaux et al. (2004; general nomenclature for rodents); (F) Marivaux et al. (2004), Antoine et al. (2012) (caviomorphs). 1 paracone; 2 protocone; 3 metacone; 4 hypocone; 5 mesostyle; 6 metaconule; 7 anteroloph; 8 protoloph; 9 mesolophule; 10 mesoloph; 11 neocrest sensu Candela (1999); 12 metaloph; 13 neoloph sensu Wood and Patterson (1959); 14 posteroloph; 15 paraflexus; 16 hypoflexus; 17 mesoflexus; 18 metaflexus; 19 posteroflexus; 20 neofossette sensu Wood and Patterson (1959). Abbreviations: ant., anterior; ling., lingual.

Figure 4. The hypotheses regarding the homology of structures on lower molars. (A) Wood and Patterson (1959; caviomorphs), Patterson and Wood (1982; caviomorphs), Carvalho and Salles 
(2004; non-tetralophodont echimyids); (B) Candela (2000; erethizontoids); (C) Marivaux et al. (2004), Antoine et al. (2012) (caviomorphs); (D) Carvalho and Salles (2004; tetralophodont echimyids); (E) Candela and Rasia (2010), (E1) non-tetralophodont echimyids, (E2) tetralophodont echimyids; (F) Verzi et al. (2014, 2016, 2017), (F1) some tetralophodont octodontoids, (F2) non-tetralophodont octodontoids. 1 protoconid; 2 metaconid; 3 mesoconid; 4 entoconid; 5 hypoconid; 6 mesostylid; 7 metalophulid I; 8 anterolophid; 9 neolophid; 10 metalophulid II ; 11 metalophid; 12 crest C (neolophid + metalophid); 13 mesolophid; 14 hypolophid; 15 posterolophid; 16 anteroflexid; 17 neoflexid; 18 mesoflexid; 19 hypoflexid; 20 metaflexid. Abbreviations: ant., anterior; ling., lingual.

Figure 5. The hypotheses regarding the homology of structures on dp4s. (A) Wood and Patterson (1959; caviomorphs), Patterson and Wood (1982; caviomorphs), Carvalho and Salles (2004; nontetralophodont echimyids); (B) Candela (2002), (B1) non-tetralophodont erethizontoids, (B2) tetralophodont erethizontoids; (C) Marivaux et al. (2004; caviomorphs), Antoine et al. (2012; caviomorphs), Candela and Rasia (2010; non-tetralophodont echimyids); (D) Carvalho and Salles (2004; tetralophodont echimyids); (E) Candela and Rasia (2010), (E1) tetralophodont echimyids configuration 1, (E2) tetralophodont echimyids configuration 2; (F) Verzi et al. (2018; caviomorphs). 1 protoconid; 2 metaconid; 3 mesoconid; 4 entoconid; 5 hypoconid; 6 mesostylid; 7 metalophulid I; 8 anterolophid; 9 neolophid sensu Candela (2002); 10 metalophulid II; 11 neolophid sensu Wood and Patterson (1959); 12 metalophid; 13 crest C (neolophid + metalophid); 14 mesolophid; 15 hypolophid; 16 posterolophid; 17 anterior cingulid (anterior cingulid). Abbreviations: ant., anterior; ling., lingual. 
Figure 6. Composition of the third transverse crest of upper teeth. (A) mesolophule and mesoloph connected; (B) mesolophule and mesoloph unconnected; (C) without mesoloph, long mesolophule; (D) without mesoloph, short mesolophule; (E) without mesolophule, long mesoloph; (F) without mesolophule, short mesoloph; $(\mathrm{G}, \mathrm{H})$ indeterminate (mesolophule and/or mesoloph). The schematic line drawings focus exclusively on the third transverse crest of upper teeth (on upper molars here). Abbreviations: ant. anterior; ant, anteroloph; H, hypocone; ling. lingual; Me, metacone; meta, metaloph; Mst, mesostyle; Pa, paracone; post, posteroloph; Pr, protocone; proto, (labial) protoloph.

Figure 7. Terminology of flexi on upper teeth. In red, third transverse crest (cf. Figure 6). Abbreviations: ant. anterior; $\mathrm{H}$, hypocone; ling. lingual; Me, metacone; Mst, mesostyle; Pa, paracone; Pr, protocone.

Figure 8. Simplified occlusal schematic line drawings of upper molars illustrating the hypotheses of transformations from a pentalophodont pattern to a tetralophodont pattern, from a tetralophodont pattern to a trilophodont pattern, and from a pentalophodont pattern to a trilophodont pattern. These schematic line drawings focus exclusively on the transformations occurring in the distolabial area of upper molars the cited taxa are example. * sensu (Vucetich and Verzi 1994). Abbreviations: ant. anterior; ant, anteroloph; H, hypocone; ling. lingual; Me, metacone; meta, metaloph; Mst, mesostyle; Pa, paracone; post, posteroloph; Pr, protocone; proto, (labial) protoloph. 
Figure 9. Photograph and interpretative schematic line drawing of the occlusal structures of the upper jaw (P4-M3) of MLP 16 VII0211, attributed to Euryzygomatomys. Abbreviations: 3rd cr, third transverse crest; ant. anterior; ant, anteroloph; H, hypocone; ling. lingual; Mst, mesostyle; Pa, paracone; post, posteroloph; Pr, protocone.

Figure 10. The posteroloph spur of upper teeth. The schematic line drawings focus exclusively on this structure (on upper molars here) and on the distolabial crests with which it can be connected. Abbreviations: ant. anterior; H, hypocone; ling. lingual; Me, metacone; Mst, mesostyle; Pa, paracone; Pr, protocone.

Figure 11. Composition of the second transverse cristid of lower molars. (A) posterior arm of the protoconid and neomesolophid connected; (B) posterior arm of the protoconid and neomesolophid unconnected; (C) without neomesolophid, long posterior arm of the protoconid; (D) without neomesolophid, short posterior arm of the protoconid; (E) without posterior arm of the protoconid, long neomesolophid; (F) without posterior arm of the protoconid, short neomesolophid; $(\mathrm{G}, \mathrm{H})$ indeterminate (posterior arm of the protoconid and/or neomesolophid). The schematic line drawings focus exclusively on the second transverse cristid. Abbreviations: ant. anterior; Ed, entoconid; Hd, hypoconid; hypod, hypolophid; ling. lingual; Md, metaconid; med I, metalophulid I ; Myd, mesostylid; Pd, protoconid; postd, posterolophid. 
Figure 12. Simplified occlusal schematic line drawings illustrating the hypotheses of transformations of pentalophodont, tetralophodont and trilophodont patterns on lower molars. The ancestral scheme remains ambiguous (scheme pentalophodont or tetralophodont). The schematic line drawings focus exclusively on the transformations observed on the mesial area of lower molars the cited taxa are example. Abbreviations: ant. anterior; Ed, entoconid; Hd, hypoconid; hypod, hypolophid; ling. lingual; Md, metaconid; med I, metalophulid I ; Myd, mesostylid; Pd, protoconid; postd, posterolophid.

Figure 13. Photographs/drawings (1) and interpretative schematic line drawings of occlusal morphologies according to Verzi et al. (2016) (2) and this study (3) of transverse cristids on lower teeth (dp4-m3s) in several octodontoid taxa. (A) Hoplomys gymnurus USP 2001; (B, I, Proechimys cuvieri MN-UFRJ 20313; (C) Lonchothrix emiliae MN-UFRJ 4856; (D) Proechimys roberti MVZ 197578; (E) Mesomys hispidus MVZ 190653; (F) Trinomys dimidiatus MN-UFRJ 62275; (G) Trinomys elegans MN-UFRJ 43842; (H) Proechimys poliopus MLP 22.II.00.7; (J) Myocastor coypus MLP 20.XII.89.3; (K) Acarechimys minutus MPM-PV 4223. This figure is based on the figure 1 of Verzi et al. (2016, p. 96) with modifications. Abbreviations: ant. anterior; ling. lingual.

Figure 14. Photographs/drawings (1) and interpretative schematic line drawings of occlusal morphologies according to Verzi et al. (2016) (2) and this study (3) of transverse cristids on lower teeth (dp4-m3s) in several octodontoid taxa. (A) Acarechimys minutus MPM-PV 4193; (B) Acaremys (Sciamys principalis) MLP 15-349; (C) Sallamys quispea (based on Shockey et al. 
2009, figure 5); (D) Sallamys pascuali UATF-V 5010; (E) Protadelphomys sp. MMP 949-M; (F)

Protadelphomys latus MPEF 90-166; (G) Protacaremys prior MPEF 5652; (H) Protacaremys prior MPEF 7557; (I) Prospaniomys priscus MPEF 6447; (J) Caviocricetus lucasi MPEF 5076; (K) Deseadomys arambourgi MLP 93-XI-21-5. This figure is a compilation realised from those of Verzi et al. (2016, figures 1-3, p. 96-98) with modifications. Abbreviations: ant. anterior; ling. lingual.

Figure 15. Composition of the second and third transverse cristids of dp4s. (A) posterior arm of the protoconid and metaconid cristid connected, mesolophid and neomesolophid connected; (B) posterior arm of the protoconid and metaconid cristid unconnected; (C) without metaconid cristid; (D) without posterior arm of the protoconid; (E) both cristids indeterminate; (F) mesolophid and neomesolophid unconnected; $(\mathrm{G})$ without neomesolophid; (H) without mesolophid. The schematic line drawings focus exclusively on the second and third transverse cristids. Abbreviations: ant. anterior; ante, anterocristid; d ectod, distal ectolophid; Ed, entoconid; Hd, hypoconid; hypod, hypolophid; ling. lingual; Md, metaconid; m ectod, mesial ectolophid; Myd, mesostylid; Pd, protoconid; postd, posterolophid.

Figure 16. The ectolophids of dp4s. The schematic line drawings focus exclusively on these structures. Abbreviations: ant. anterior; ante, anterocristid; d ectod, distal ectolophid; Ed, entoconid; Hd, hypoconid; hypod, hypolophid; ling. lingual; Md, metaconid; m ectod, mesial ectolophid; Myd, mesostylid; Pd, protoconid; postd, posterolophid. 
Figure 17. Simplified occlusal schematic line drawings illustrating the hypotheses of transformations of hexalophodont, pentalophodont and tetralophodont patterns of dp4s. The ancestral scheme remains ambiguous (scheme pentalophodont or tetralophodont). These schematic line drawings focused exclusively on transformations of the trigonid of dp $4 \mathrm{~s}$ the cited taxa are example. Abbreviations: ant. anterior; ante, anterocristid; d ectod, distal ectolophid; Ed, entoconid; Hd, hypoconid; hypod, hypolophid; ling. lingual; Md, metaconid; m ectod, mesial ectolophid; Myd, mesostylid; Pd, protoconid; postd, posterolophid. 

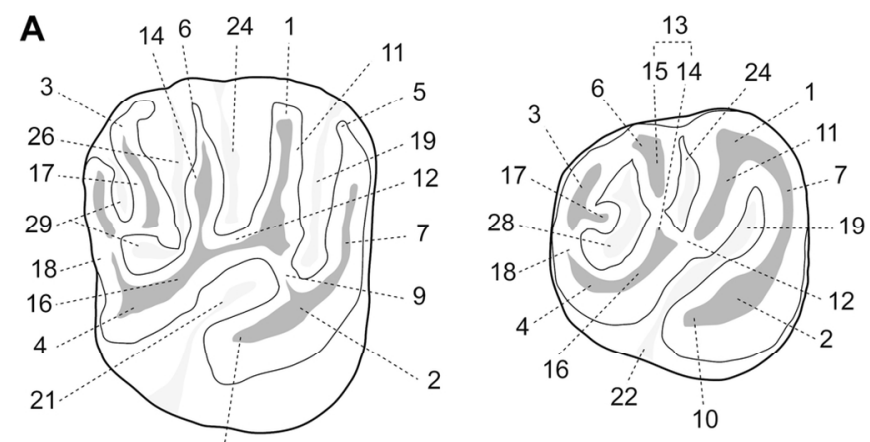

B

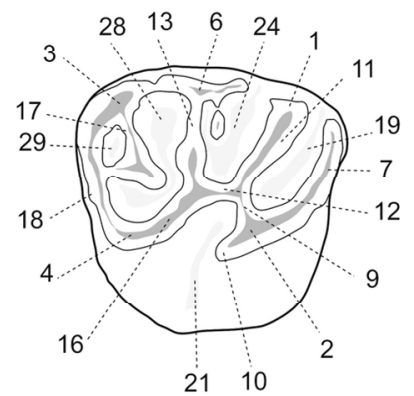

C

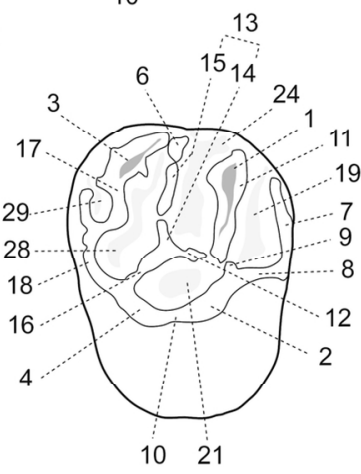

D

E
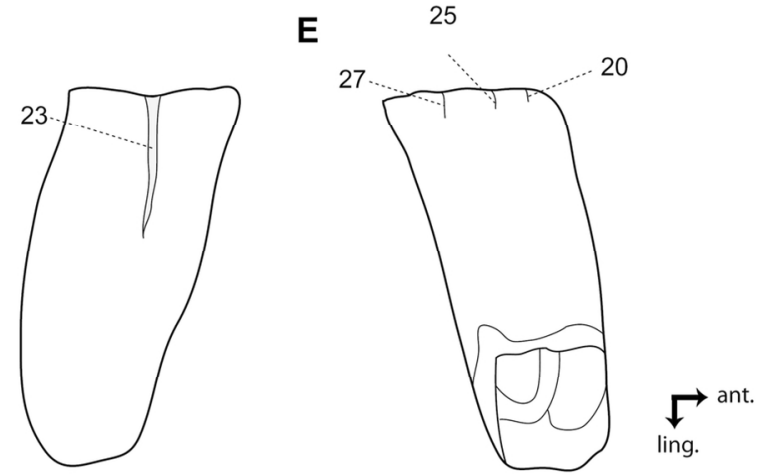

Figure 1. Nomenclature of upper teeth used in this study. (A) occlusal view of upper molar (based of two different specimens); (B) occlusal view of DP4; (C) occlusal view of P4; (D) lingual view of upper tooth; (E) labial view of upper tooth. The nomenclature is based on the dental terminology of different authors (see text) and on the observations carried out in the context of this study. 1, paracone; 2, protocone; 3 , metacone; 4, hypocone; 5, parastyle; 6, mesostyle; 7, anteroloph; 8, anterior arm of the protocone; 9, lingual protoloph (= posterior arm of the protocone); 10, posterior outgrowth of the protocone; 11, protoloph (= labial protoloph); 12, mure; 13, third transverse crest (= central transverse crest); 14, mesolophule; 15, mesoloph; 16, anterior arm of the hypocone; 17, metaloph; 18, posteroloph; 19, paraflexus; 20 , parastria; 21 , hypoflexus/hypofossette; 22 , confluence of the paraflexus with the hypoflexus; 23, hypostria; 24, mesial mesoflexus/mesofossette; 25, mesostria; 26, distal mesoflexus/mesofossette; 27 , metastria; 28 , confluence of the distal mesoflexus with the metaflexus (i.e., posteroflexus); 29, posteroflexus. Abbreviations: ant., anterior; ling., lingual. 

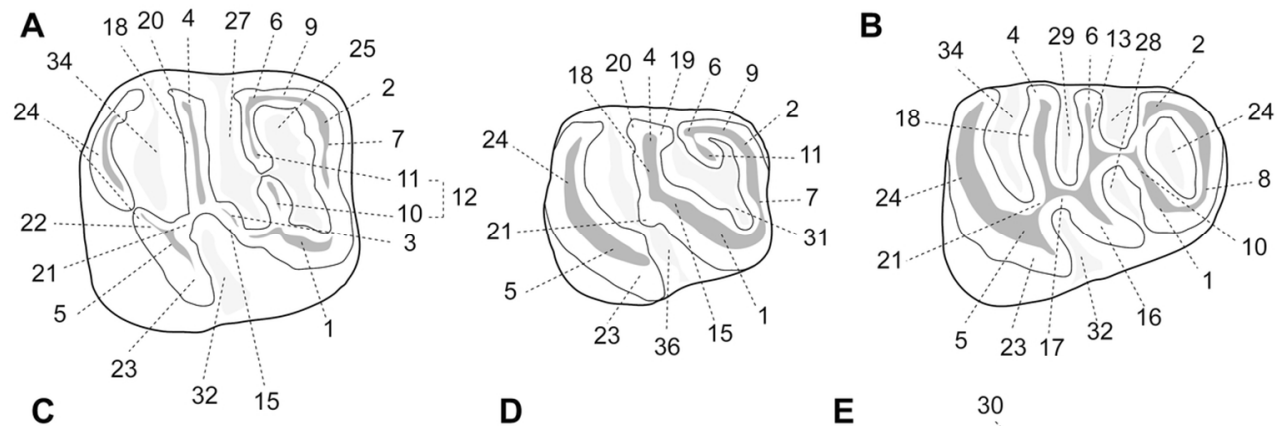

C
D

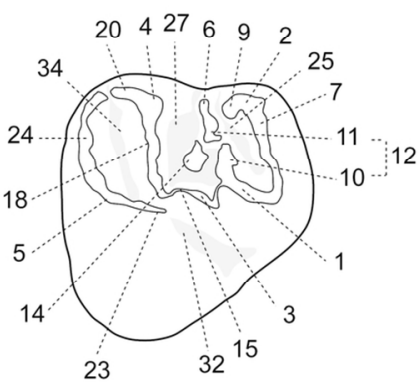

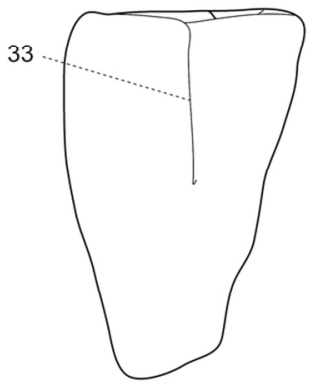

E

30

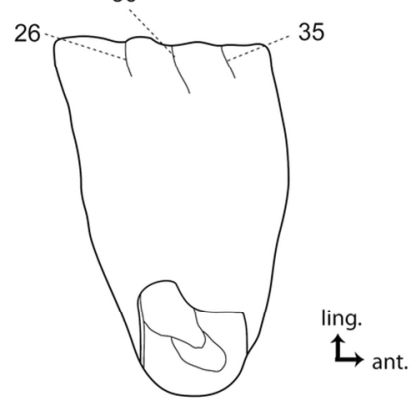

Figure 2. Nomenclature of lower teeth used in this study. (A) occlusal view of lower molar (based of two different specimens); (B) occlusal view of dp4; (C) occlusal view of p4; (D) labial view of lower tooth; (E) lingual view of lower tooth. The nomenclature is based on the dental terminology of different authors (see text) and on the observations carried out in the context of this study. 1, protoconid; 2, metaconid; 3, mesoconid; 4, entoconid; 5, hypoconid; 6, mesostylid; 7, metalophulid I; 8, anterocristid; 9, posterior arm of the metaconid; 10, posterior arm of the protoconid; 11, neomesolophid; 12, second transverse cristid; 13, mesolophid; 14, rest of the mesolophid?; 15, ectolophid; 16, mesial ectolophid; 17, distal ectolophid; 18 , hypolophid; 19 , anterior arm of the entoconid; 20 , posterior arm of the entoconid; 21 , anterior arm of the hypoconid; 22, posterior arm of the hypoconid; 23, anterior outgrowth of the hypoconid; 24, posterolophid; 25, anteroflexid/anterofossettid; 26, anterostriid; 27, mesoflexid; 28, mesial mesoflexid; 29, distal mesoflexid; 30, mesostriid; 31, confluence of the anteroflexid with the mesoflexid; 32, hypoflexid; 33, hypostriid; 34, metaflexid; 35, metastriid; 36, confluence of the hypoflexid with the metaflexid. Abbreviations: ant., anterior; ling., lingual.

$113 \times 74 \mathrm{~mm}(300 \times 300 \mathrm{DPI})$ 

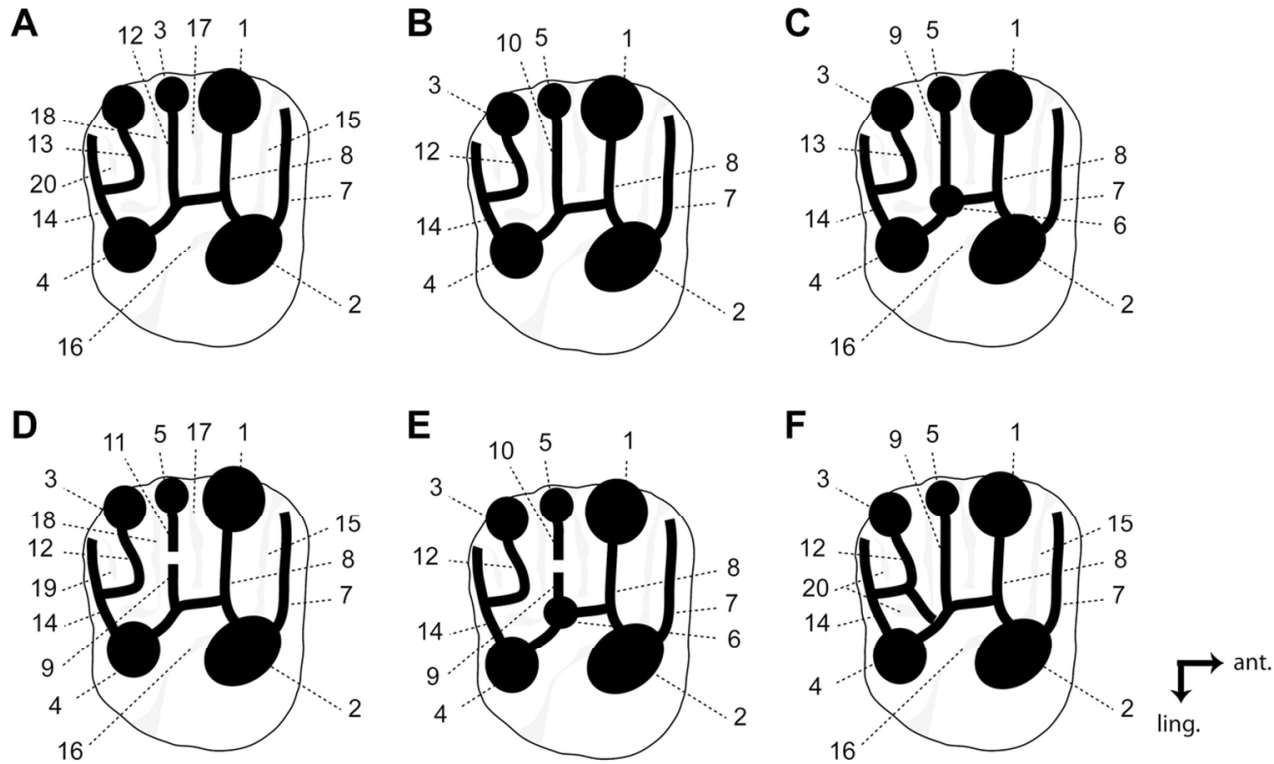

Figure 3. The hypotheses regarding the homology of structures on upper molars. (A) Wood and Patterson (1959), Patterson and Wood (1982) (caviomorphs); (B) Hoffstetter and Lavocat (1970), Lavocat (1976)

(caviomorphs); (C) Bryant and McKenna (1995; 'phiomorphs' and caviomorphs); (D) Candela (1999; erethizontoids); (E) Marivaux et al. (2004; general nomenclature for rodents); (F) Marivaux et al. (2004), Antoine et al. (2012) (caviomorphs). 1 paracone; 2 protocone; 3 metacone; 4 hypocone; 5 mesostyle; 6 metaconule; 7 anteroloph; 8 protoloph; 9 mesolophule; 10 mesoloph; 11 neocrest sensu Candela (1999); 12 metaloph; 13 neoloph sensu Wood and Patterson (1959); 14 posteroloph; 15 paraflexus; 16 hypoflexus; 17 mesoflexus; 18 metaflexus; 19 posteroflexus; 20 neofossette sensu Wood and Patterson (1959). Abbreviations: ant., anterior; ling., lingual.

$113 \times 69 \mathrm{~mm}(300 \times 300$ DPI $)$ 

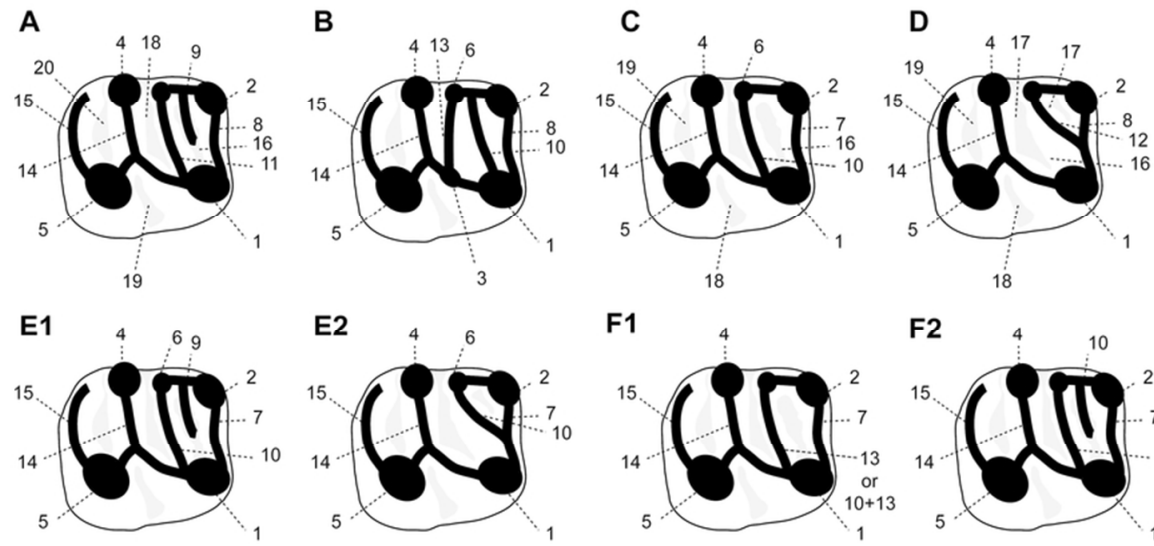

F1

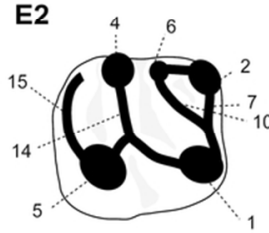

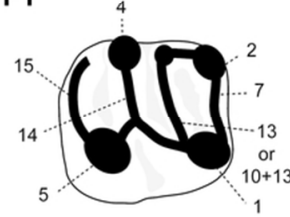

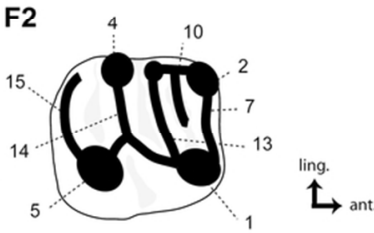

Figure 4. The hypotheses regarding the homology of structures on lower molars. (A) Wood and Patterson (1959; caviomorphs), Patterson and Wood (1982; caviomorphs), Carvalho and Salles (2004; nontetralophodont echimyids); (B) Candela (2000; erethizontoids); (C) Marivaux et al. (2004), Antoine et al. (2012) (caviomorphs); (D) Carvalho and Salles (2004; tetralophodont echimyids); (E) Candela and Rasia (2010), (E1) non-tetralophodont echimyids, (E2) tetralophodont echimyids; (F) Verzi et al. (2014, 2016, 2017), (F1) some tetralophodont octodontoids, (F2) non-tetralophodont octodontoids. 1 protoconid; 2 metaconid; 3 mesoconid; 4 entoconid; 5 hypoconid; 6 mesostylid; 7 metalophulid I; 8 anterolophid; 9 neolophid; 10 metalophulid II ; 11 metalophid; 12 crest C (neolophid + metalophid); 13 mesolophid; 14 hypolophid; 15 posterolophid; 16 anteroflexid; 17 neoflexid; 18 mesoflexid; 19 hypoflexid; 20 metaflexid. Abbreviations: ant., anterior; ling., lingual.

$82 \times 36 \mathrm{~mm}(300 \times 300 \mathrm{DPI})$ 


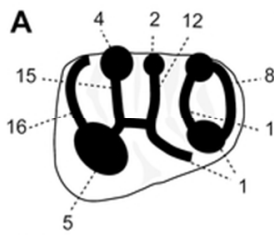

B1

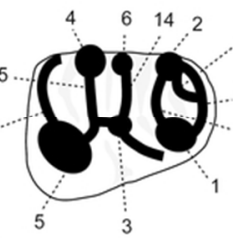

D 4

E1

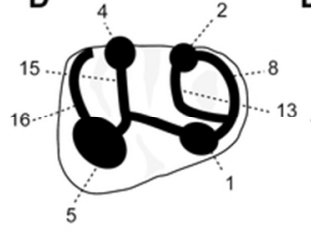

E1
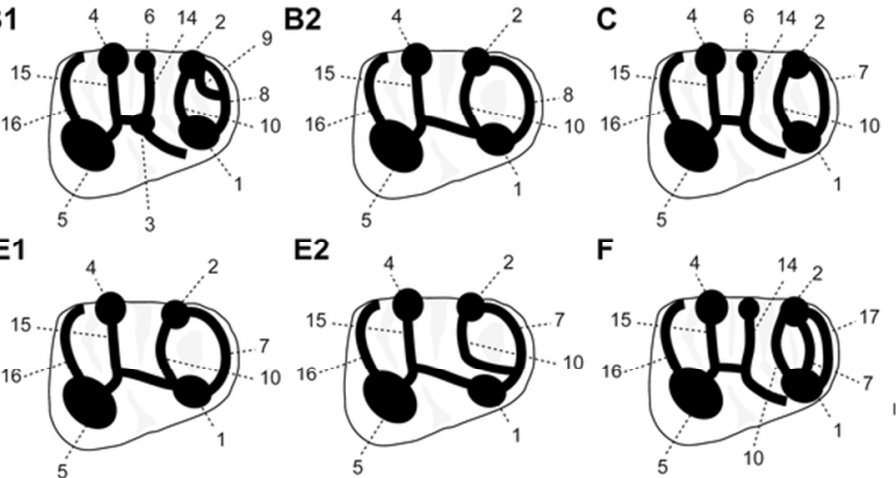

E2

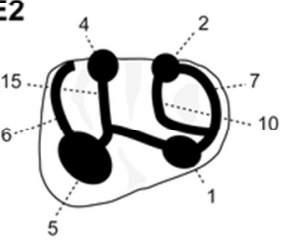

F

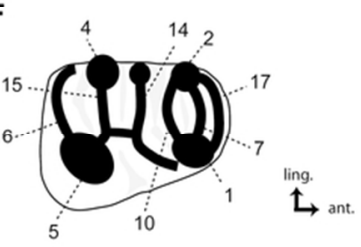

Figure 5. The hypotheses regarding the homology of structures on dp4s. (A) Wood and Patterson (1959; caviomorphs), Patterson and Wood (1982; caviomorphs), Carvalho and Salles (2004; non-tetralophodont echimyids); (B) Candela (2002), (B1) non-tetralophodont erethizontoids, (B2) tetralophodont erethizontoids; (C) Marivaux et al. (2004; caviomorphs), Antoine et al. (2012; caviomorphs), Candela and Rasia (2010; non-tetralophodont echimyids); (D) Carvalho and Salles (2004; tetralophodont echimyids); (E) Candela and Rasia (2010), (E1) tetralophodont echimyids configuration 1, (E2) tetralophodont echimyids configuration 2; (F) Verzi et al. (2018; caviomorphs). 1 protoconid; 2 metaconid; 3 mesoconid; 4 entoconid; 5 hypoconid; 6 mesostylid; 7 metalophulid I; 8 anterolophid; 9 neolophid sensu Candela (2002); 10 metalophulid II; 11 neolophid sensu Wood and Patterson (1959); 12 metalophid; 13 crest C (neolophid + metalophid); 14 mesolophid; 15 hypolophid; 16 posterolophid; 17 anterior cingulid (anterior cingulid). Abbreviations: ant., anterior; ling., lingual.

$72 \times 28 \mathrm{~mm}(300 \times 300 \mathrm{DPI})$ 

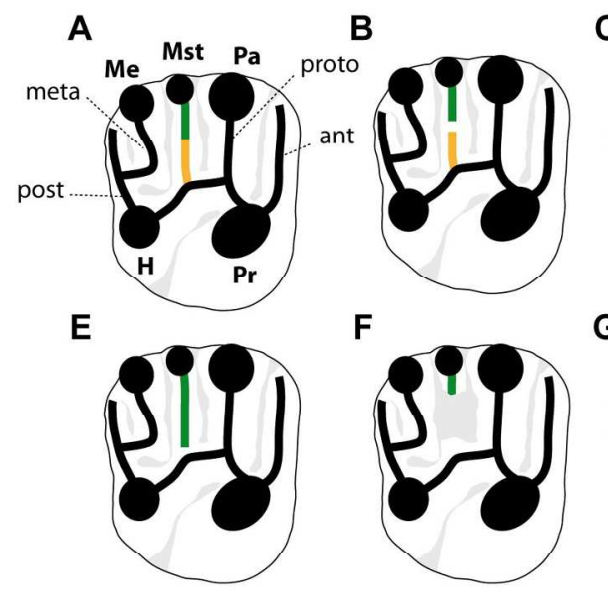

F

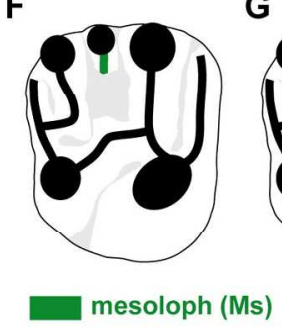

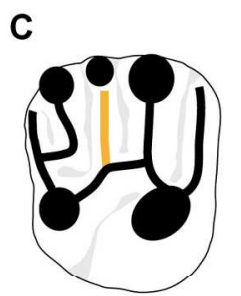

G

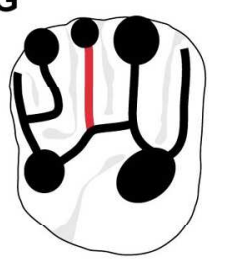

H
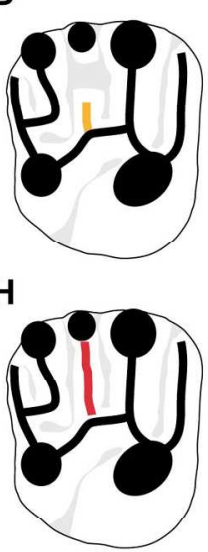

third transverse crest (Msul and/or Ms)

Figure 6. Composition of the third transverse crest of upper teeth. (A) mesolophule and mesoloph connected; (B) mesolophule and mesoloph unconnected; (C) without mesoloph, long mesolophule; (D) without mesoloph, short mesolophule; (E) without mesolophule, long mesoloph; (F) without mesolophule, short mesoloph; (G, H) indeterminate (mesolophule and/or mesoloph). The schematic line drawings focus exclusively on the third transverse crest of upper teeth (on upper molars here). Abbreviations: ant. anterior; ant, anteroloph; $\mathrm{H}$, hypocone; ling. lingual; Me, metacone; meta, metaloph; Mst, mesostyle; Pa, paracone; post, posteroloph; Pr, protocone; proto, (labial) protoloph. 
Figure 7. Terminology of flexi on upper teeth. In red, third transverse crest (cf. Figure 6). Abbreviations: ant. anterior; $\mathrm{H}$, hypocone; ling. lingual; Me, metacone; Mst, mesostyle; Pa, paracone; Pr, protocone.

$82 \times 63 \mathrm{~mm}(300 \times 300$ DPI $)$ 


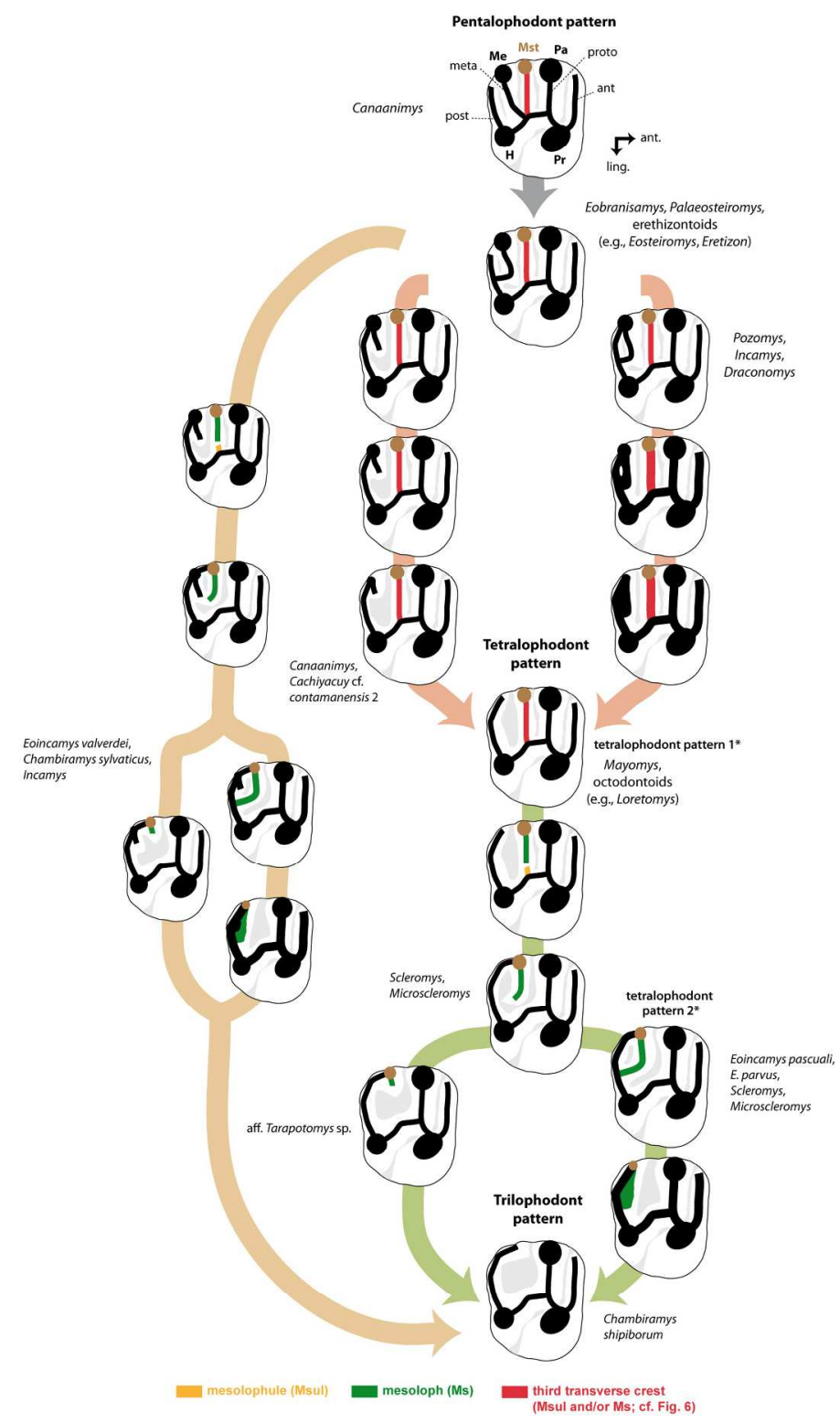

Figure 8. Simplified occlusal schematic line drawings of upper molars illustrating the hypotheses of transformations from a pentalophodont pattern to a tetralophodont pattern, from a tetralophodont pattern to a trilophodont pattern, and from a pentalophodont pattern to a trilophodont pattern. These schematic line drawings focus exclusively on the transformations occurring in the distolabial area of upper molars the cited taxa are example. * sensu (Vucetich and Verzi 1994). Abbreviations: ant. anterior; ant, anteroloph; $H$, hypocone; ling. lingual; Me, metacone; meta, metaloph; Mst, mesostyle; Pa, paracone; post, posteroloph; $\mathrm{Pr}$, protocone; proto, (labial) protoloph.

$$
172 \times 231 \mathrm{~mm}(300 \times 300 \mathrm{DPI})
$$



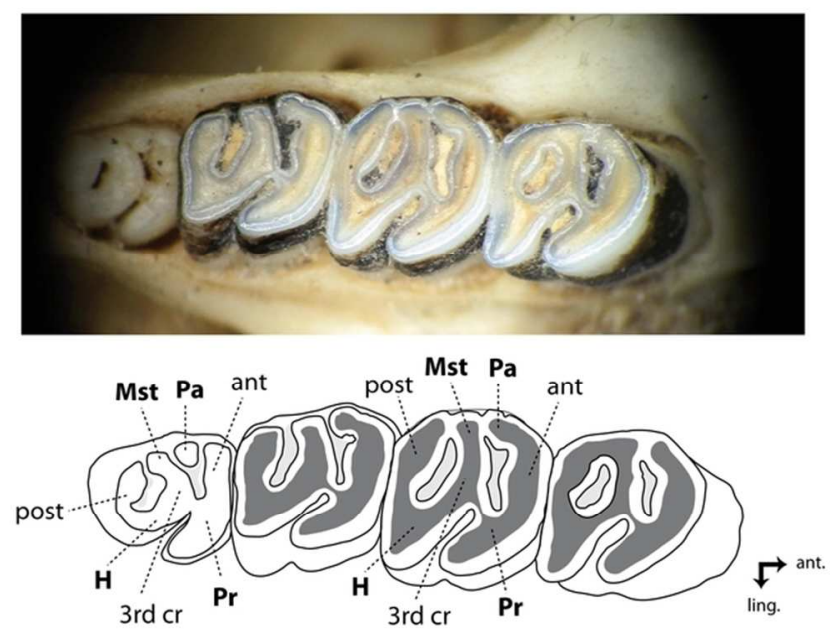

Figure 9. Photograph and interpretative schematic line drawing of the occlusal structures of the upper jaw (P4-M3) of MLP 16 VII0211, attributed to Euryzygomatomys. Abbreviations: 3rd cr, third transverse crest; ant. anterior; ant, anteroloph; $\mathrm{H}$, hypocone; ling. lingual; Mst, mesostyle; Pa, paracone; post, posteroloph; $\mathrm{Pr}$, protocone.

\section{$86 \times 43 \mathrm{~mm}(300 \times 300 \mathrm{DPI})$}




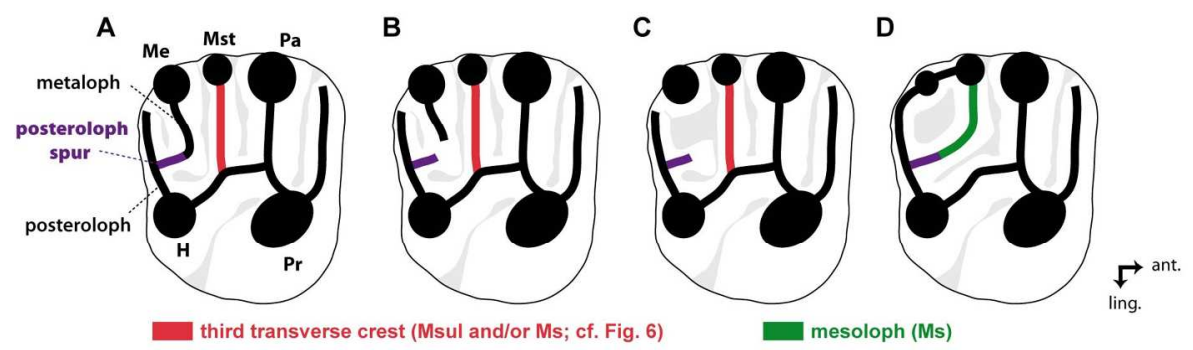

Figure 10. The posteroloph spur of upper teeth. The schematic line drawings focus exclusively on this structure (on upper molars here) and on the distolabial crests with which it can be connected. Abbreviations: ant. anterior; $\mathrm{H}$, hypocone; ling. lingual; Me, metacone; Mst, mesostyle; $\mathrm{Pa}$, paracone; $\mathrm{Pr}$, protocone.

$173 \times 47 \mathrm{~mm}(300 \times 300$ DPI $)$ 


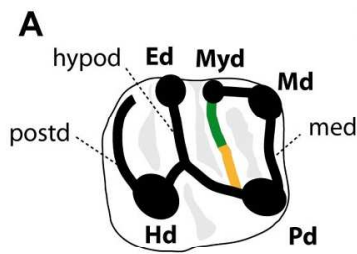

B

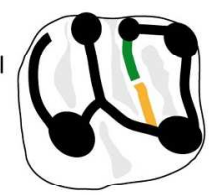

E

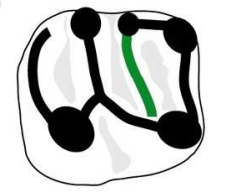

F

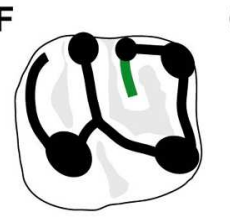

G

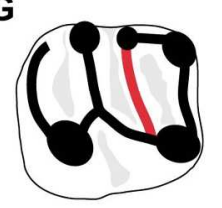

C
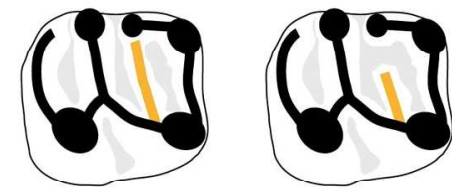

H

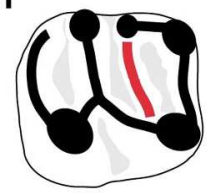

posterior arm of the

neomesolophid (Neom) second

transverse cristid (Neom and/or PAP)

Figure 11. Composition of the second transverse cristid of lower molars. (A) posterior arm of the protoconid and neomesolophid connected; (B) posterior arm of the protoconid and neomesolophid unconnected; (C) without neomesolophid, long posterior arm of the protoconid; (D) without neomesolophid, short posterior arm of the protoconid; (E) without posterior arm of the protoconid, long neomesolophid; (F) without posterior arm of the protoconid, short neomesolophid; $(\mathrm{G}, \mathrm{H}$ ) indeterminate (posterior arm of the protoconid and/or neomesolophid). The schematic line drawings focus exclusively on the second transverse cristid. Abbreviations: ant. anterior; Ed, entoconid; Hd, hypoconid; hypod, hypolophid; ling. lingual; Md, metaconid; med I, metalophulid I ; Myd, mesostylid; Pd, protoconid; postd, posterolophid. 


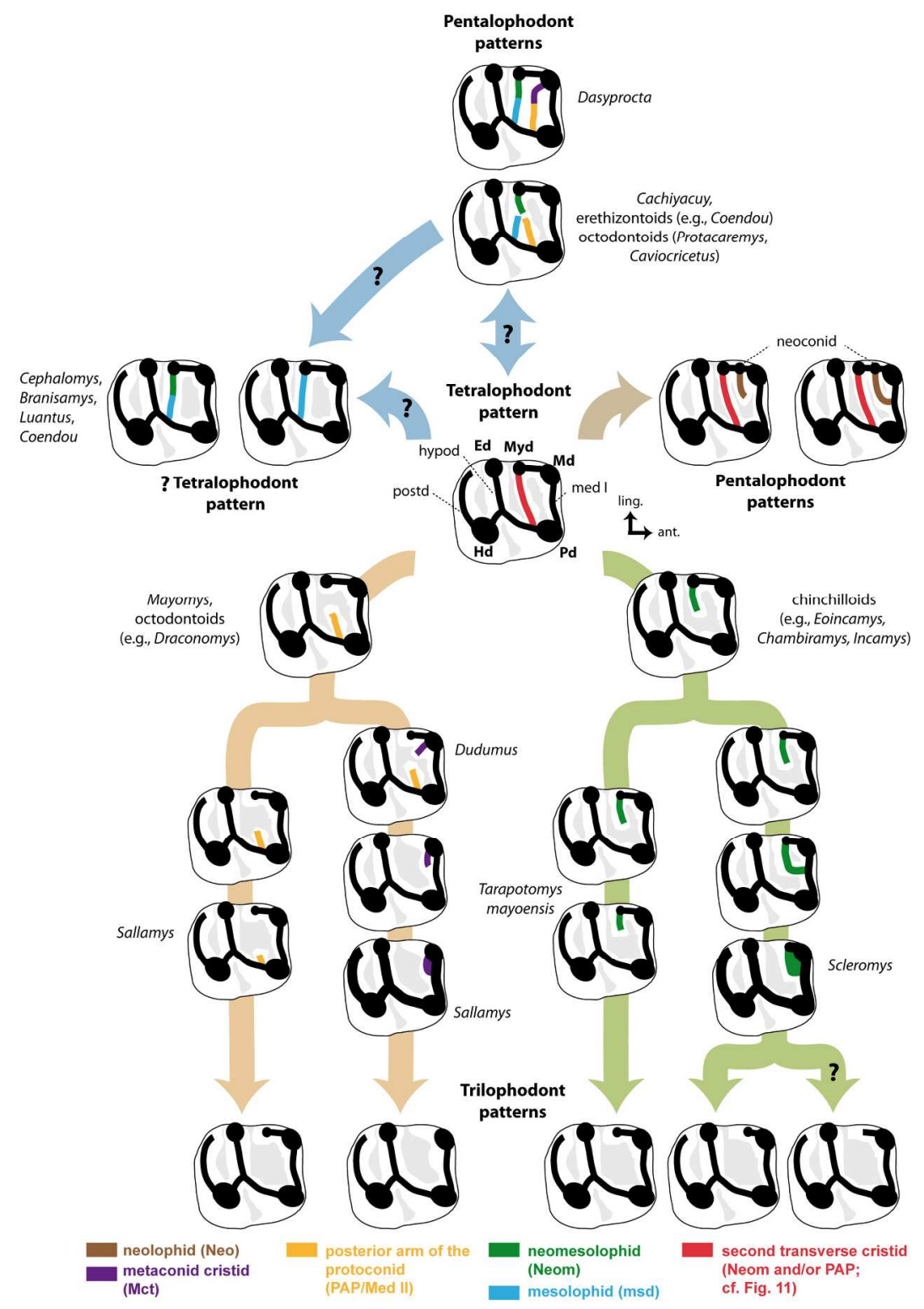

Figure 12. Simplified occlusal schematic line drawings illustrating the hypotheses of transformations of pentalophodont, tetralophodont and trilophodont patterns on lower molars. The ancestral scheme remains ambiguous (scheme pentalophodont or tetralophodont). The schematic line drawings focus exclusively on the transformations observed on the mesial area of lower molars the cited taxa are example. Abbreviations: ant. anterior; Ed, entoconid; Hd, hypoconid; hypod, hypolophid; ling. lingual; Md, metaconid; med I, metalophulid I ; Myd, mesostylid; Pd, protoconid; postd, posterolophid. 


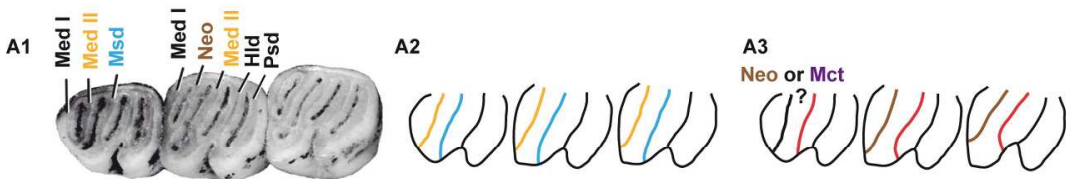

B1

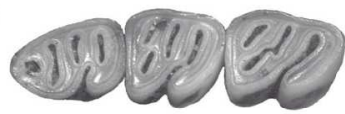

B2

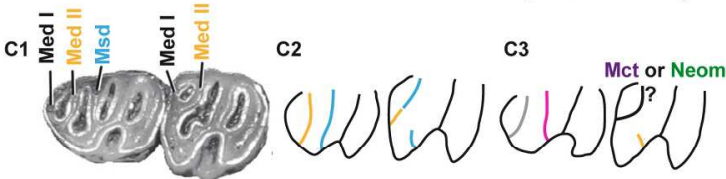

E1

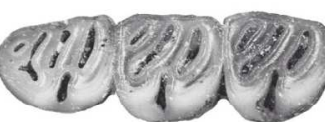

F1

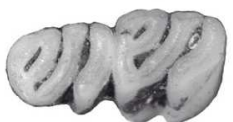

G1

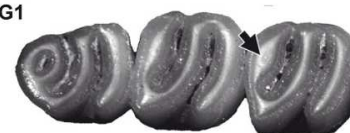

H1
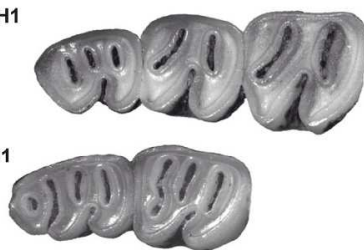

J1

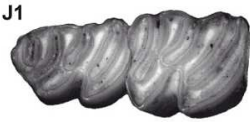

K1

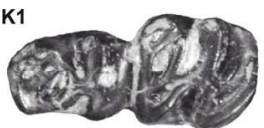

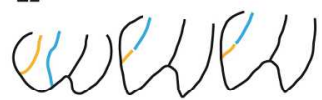

F2

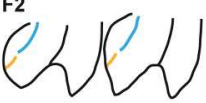

G2

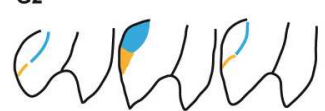

12
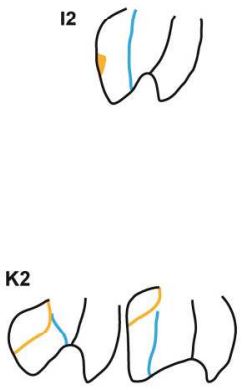

B3
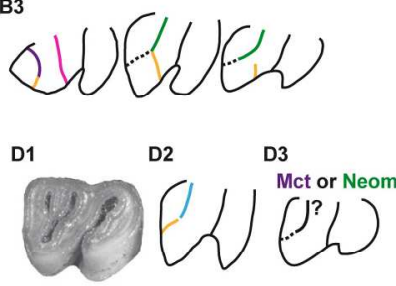

E3

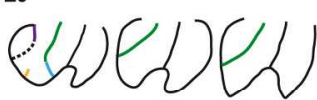

F3

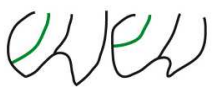

G3

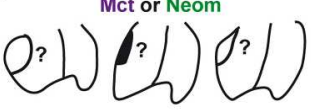

H3

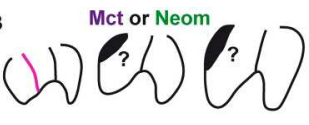

13

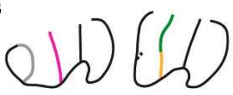

J3

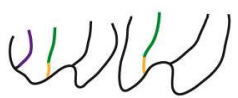

K3

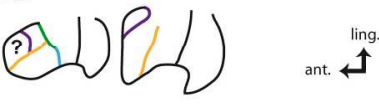

neolophide (Neo)

Mct and/or PAP

Neom and/or PAP Neom and/or msd

metaconid cristid (Mct)

Figure 13. Photographs/drawings (1) and interpretative schematic line drawings of occlusal morphologies according to Verzi et al. (2016) (2) and this study (3) of transverse cristids on lower teeth (dp4-m3s) in several octodontoid taxa. (A) Hoplomys gymnurus USP 2001; (B, I, Proechimys cuvieri MN-UFRJ 20313; (C)

Lonchothrix emiliae MN-UFRJ 4856; (D) Proechimys roberti MVZ 197578; (E) Mesomys hispidus MVZ 190653; (F) Trinomys dimidiatus MN-UFRJ 62275; (G) Trinomys elegans MN-UFRJ 43842; (H) Proechimys poliopus MLP 22.II.00.7; (J) Myocastor coypus MLP 20.XII.89.3; (K) Acarechimys minutus MPM-PV 4223.

This figure is based on the figure 1 of Verzi et al. (2016, p. 96) with modifications. Abbreviations: ant. anterior; ling. lingual.

$173 \times 232 \mathrm{~mm}(300 \times 300 \mathrm{DPI})$ 
A1

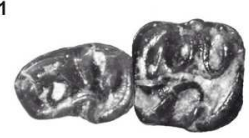

B1

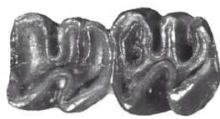

c1

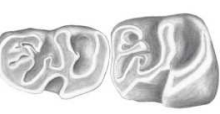

D1

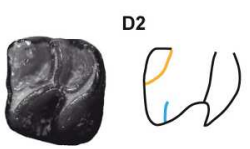

F1

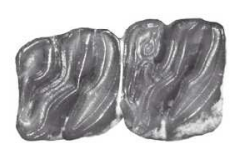

G1

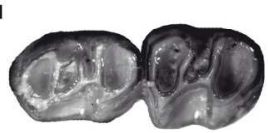

H1
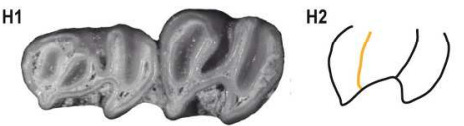

11
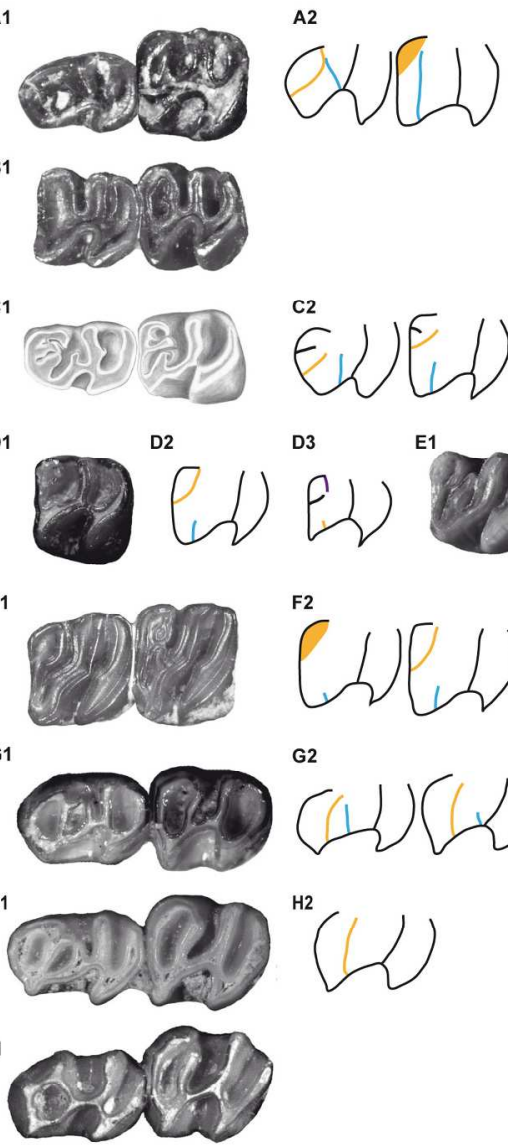

A3

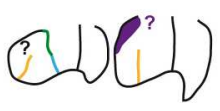

B3<smiles></smiles>

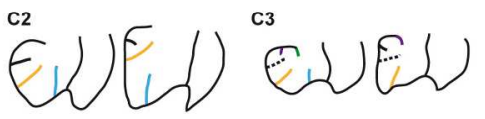

D3<smiles>CCCCC(C)CCC</smiles>

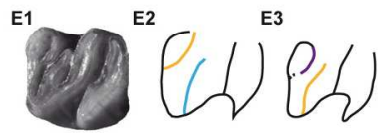

F2
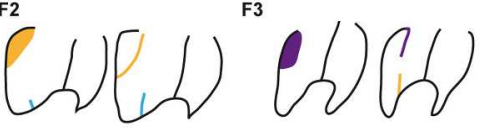

G2

G3

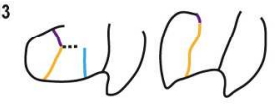

13

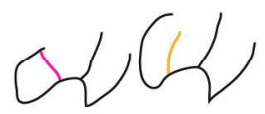

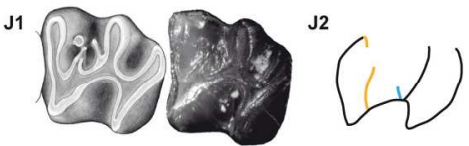

J3

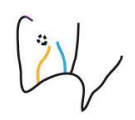

K3

K1
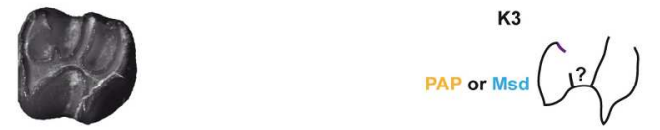

ant. $\stackrel{\text { ling. }}{\ddagger}$

neomsolophid (Neom) Neom and/or msd

mesolophid (msd) _...-... other secondary structures

Figure 14. Photographs/drawings (1) and interpretative schematic line drawings of occlusal morphologies according to Verzi et al. (2016) (2) and this study (3) of transverse cristids on lower teeth (dp4-m3s) in several octodontoid taxa. (A) Acarechimys minutus MPM-PV 4193; (B) Acaremys (Sciamys principalis) MLP 15-349; (C) Sallamys quispea (based on Shockey et al. 2009, figure 5); (D) Sallamys pascuali UATF-V 5010; (E) Protadelphomys sp. MMP 949-M; (F) Protadelphomys latus MPEF 90-166; (G) Protacaremys prior MPEF 5652; (H) Protacaremys prior MPEF 7557; (I) Prospaniomys priscus MPEF 6447; (J) Caviocricetus lucasi MPEF 5076; (K) Deseadomys arambourgi MLP 93-XI-21-5. This figure is a compilation realised from those of Verzi et al. (2016, figures 1-3, p. 96-98) with modifications. Abbreviations: ant. anterior; ling. lingual.

$173 \times 232 \mathrm{~mm}(300 \times 300 \mathrm{DPI})$ 

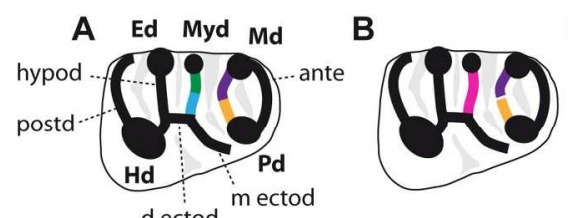

C

E

F
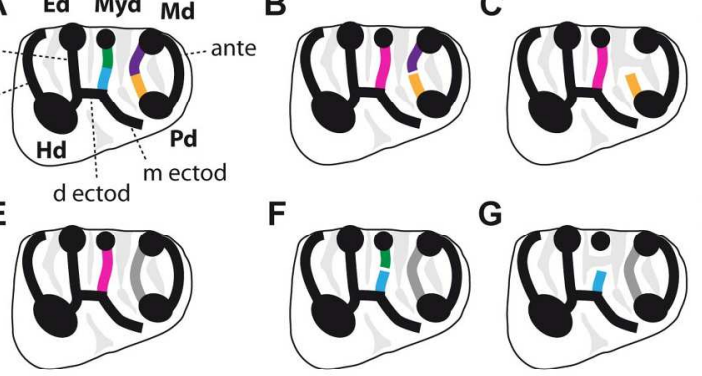

D
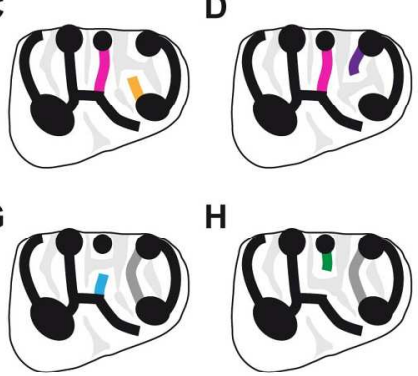

$\mathrm{H}$

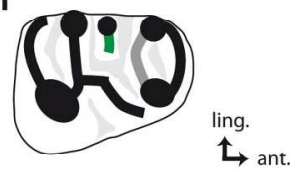

posterior arm of the protoconid (PAP/Med II) metaconid cristid (Mct) Mct and/or PAP

Figure 15. Composition of the second and third transverse cristids of dp4s. (A) posterior arm of the protoconid and metaconid cristid connected, mesolophid and neomesolophid connected; (B) posterior arm of the protoconid and metaconid cristid unconnected; (C) without metaconid cristid; (D) without posterior arm

of the protoconid; (E) both cristids indeterminate; (F) mesolophid and neomesolophid unconnected; (G) without neomesolophid; $(\mathrm{H})$ without mesolophid. The schematic line drawings focus exclusively on the second and third transverse cristids. Abbreviations: ant. anterior; ante, anterocristid; d ectod, distal ectolophid; Ed, entoconid; Hd, hypoconid; hypod, hypolophid; ling. lingual; Md, metaconid; m ectod, mesial ectolophid; Myd, mesostylid; Pd, protoconid; postd, posterolophid.

\section{$172 \times 70 \mathrm{~mm}(300 \times 300$ DPI $)$}


Figure 16. The ectolophids of dp4s. The schematic line drawings focus exclusively on these structures. Abbreviations: ant. anterior; ante, anterocristid; d ectod, distal ectolophid; Ed, entoconid; Hd, hypoconid hypod, hypolophid; ling. lingual; Md, metaconid; m ectod, mesial ectolophid; Myd, mesostylid; Pd, protoconid; postd, posterolophid.

$172 \times 50 \mathrm{~mm}(300 \times 300 \mathrm{DPI})$ 
Figure 17. Simplified occlusal schematic line drawings illustrating the hypotheses of transformations of hexalophodont, pentalophodont and tetralophodont patterns of dp4s. The ancestral scheme remains ambiguous (scheme pentalophodont or tetralophodont). These schematic line drawings focused exclusively on transformations of the trigonid of dp4s the cited taxa are example. Abbreviations: ant. anterior; ante, anterocristid; d ectod, distal ectolophid; Ed, entoconid; Hd, hypoconid; hypod, hypolophid; ling. lingual; Md, metaconid; m ectod, mesial ectolophid; Myd, mesostylid; Pd, protoconid; postd, posterolophid.

$$
173 \times 235 \mathrm{~mm}(300 \times 300 \mathrm{DPI})
$$




\section{Supplemental Online Material}

Caviomorph taxa used for comparisons in this study. 


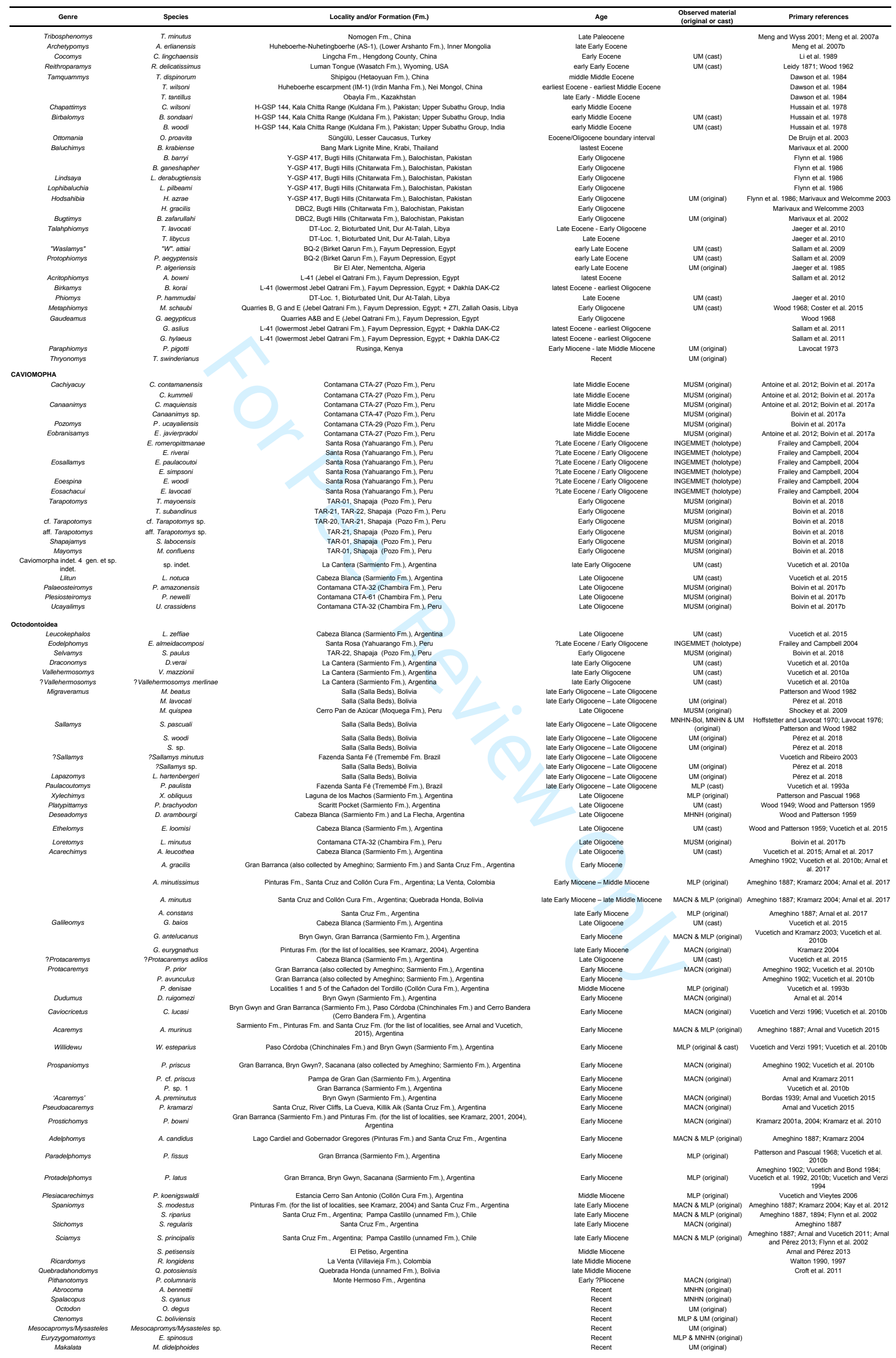

URL: http://mc.manuscriptcentral.com/ghbi 


\begin{tabular}{|c|c|c|c|c|c|}
\hline Genre & Species & Locality and/or Formation (Fm.) & Age & $\begin{array}{l}\text { Observed material } \\
\text { (original or cast) }\end{array}$ & Primary references \\
\hline 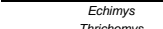 & E. chrysurus & & 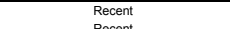 & UM (original) & \\
\hline Thrichomys & T. apereoides & & Recent & MNHN (original) & \\
\hline Proechimys & P. cuvieri & & Recent & UM (original) & \\
\hline Myocastor & M. coypus & & Recent & uM (original) & \\
\hline \multicolumn{6}{|l|}{ Erethizontoidea } \\
\hline Eopululo & E. wigmorei & Santa Rosa (Yahuarango $\mathrm{Fm}$.$) , Peru$ & ?Late Eocene / Early Oligocene & INGEMMET (holotype) & Frailey and Campbell, 2004 \\
\hline Kichkasteiromys & K. raimondii & & Early Oligocene & MUSM (original) & Boivin et al. 2018 \\
\hline \multirow[t]{2}{*}{ Protosteiromys } & $\begin{array}{l}\text { P. medianus } \\
\text { P. asmodeophilus }\end{array}$ & $\begin{array}{l}\text { Cabeza Blanca and La Flecha (Sarmiento Fm.), Argentina } \\
\text { La Flecha (Sarmiento Fm.), Argentina }\end{array}$ & $\begin{array}{l}\text { Late Oligocene } \\
\text { Late Oligocene }\end{array}$ & $\begin{array}{l}\text { MACN \& MHNH (original) } \\
\text { MHNH (original) }\end{array}$ & $\begin{array}{l}\text { Ameghino 1903; Wood and Patterson } 1959 \\
\text { Wood and Patterson } 1959\end{array}$ \\
\hline & P. pattersoni & Salla (Salla Beds), Bolvivia & late Early Oligocene - Late Oligocene & $\begin{array}{l}\text { MNHN-Bol, MNHN \& UM } \\
\text { (original) }\end{array}$ & Candela 2000; Pérez et al. 2018 \\
\hline Cholamys & C. tetralophodonta & Salla (Salla Beds), Bolivia & late Early Oligocene - Late Oligocene & UM (original) & Pérez et al. 2018 \\
\hline \multirow[t]{2}{*}{ Hypsosteiromys } & H. axiculus & Bryn Gwyn and Grand Barranca (also collected by Ameghino, Sarmiento Fm.), Argentina & Early Miocene & MACN (original) & $\begin{array}{l}\text { Ameghino 1902; Candela 2000; Candela and } \\
\text { Vucetich 2002; Vucetich et al. 2010b }\end{array}$ \\
\hline & H. nectus & Gran Barranca (also collected by Ameghino, Sarmiento Fm.), Argentina & Early Miocene & MACN \& MLP (original) & $\begin{array}{l}\text { Ameghinin 1992; ; ardelala 2000; Candela and } \\
\text { Vucetich 2002; vucetich et al. 2010b }\end{array}$ \\
\hline \multirow[t]{2}{*}{ Steiromys } & s. detentus & Santa Cruz Fm., Argentina & Early Miocene & MACN \& MLP (original) & $\begin{array}{l}\text { Ameghino 1887; Candela 2000; Candela et al. } \\
2012 ; \text { Kay et al. } 2012\end{array}$ \\
\hline & s. duplicatus & Santa Cruz Fm., Argentina; Pampa Castillo (unnamed Fm.), Chile & Early Miocene & MACN \& MLP (original) & 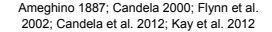 \\
\hline \multirow[t]{2}{*}{ Parasteiromys } & P. uniformis & $\begin{array}{l}\text { Southern Cliff of Lake Colhué Huapi (Gran Barranca and also collected by Ameghino; Sarmiento Fm.). } \\
\text { Argentina }\end{array}$ & Early Miocene & MACN \& MLP (original) & $\begin{array}{l}\text { Ameghino 1903, 1904; Candela 1999, 2000; } \\
\text { Vucetich et al 2010b }\end{array}$ \\
\hline & P. friantae & Southem Cliff of Lake Collué Huapi (Gran Barranca; Sarmiento Fm.), Argentina & Early Miocene & MLP (original) & Candela 1999, 2000; Vucetich et al. $2010 \mathrm{~b}$ \\
\hline Eosteiromys & E. homogidens & Bryn Gwyn and Grand Barranca (also collected by Ameghino, Sarmiento Fm.), Argentina & Early Miocene & MACN \& MLP (original) & $\begin{array}{l}\text { Ameghino 1902; Candele a } 2000 \text {; Vucetich et al. } \\
2010 \mathrm{~b}\end{array}$ \\
\hline \multirow{2}{*}{$\begin{array}{l}\text { PEosielomys } \\
\text { Branisamyopsis }\end{array}$} & PEosteiromys sp. nov. & & Early Miocene & & Candela 2002 \\
\hline & $\begin{array}{l}\text { B. australis } \\
\text { B. preasigmoides }\end{array}$ & $\begin{array}{l}\text { Southem Cliff of Lake Colhué Huapi (Gran Barranca; Sarmiento Fm.), Argentina } \\
\text { Pinturas } \mathrm{Fm} \text {. (for the list of localities, see Kramarz, 2004), Argentina }\end{array}$ & Early Miocene & MLP \& MHNH (original) & Candela 2000, 2003; Vucetich et al. 2010b \\
\hline ?Neosteiromys & ?Neosteiromys tordillense & 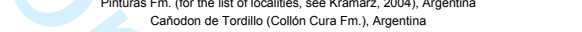 & Middle Miocenene & MACN (original) & Vucetich et al. $1993 \mathrm{~b}$ \\
\hline Microsteiromys & M. jacobsi & La Venta (Villavieja Fm.), Colombia & late Middle Miocene & & Walton 1990, 1997 \\
\hline Neosteiromys & cf. Microsteitumys sp. & $\begin{array}{l}\text { Madre de Dios MD-67 (unnamedFm.), Peru } \\
\text { Catatamarca revonince (Andalhaula Fm.). Aregntina }\end{array}$ & $\begin{array}{l}\text { Middle Miocene } \\
\text { late Milcene }\end{array}$ & MIUSM (original) & $\begin{array}{l}\text { Antinine et al. } 2013 \\
\text { Candela 2000. } 2004\end{array}$ \\
\hline Neosierromys & $\begin{array}{l}\text { N. pamboni } \\
\text { N. bomifrons }\end{array}$ & $\begin{array}{l}\text { Catamarcca Provinine (Andahuala Fm.,.,Argentina } \\
\text { Andalluala Fm., Argentina }\end{array}$ & $\begin{array}{l}\text { late Miocene } \\
\text { late Miocene }\end{array}$ & MACN (original) & $\begin{array}{l}\text { Candela 2000, } 2004 \\
\text { Candela 2000, } 2004\end{array}$ \\
\hline Coendou & $\begin{array}{l}\text { C. prehensilis } \\
\text { C. insidious }\end{array}$ & & $\begin{array}{l}\text { Recent } \\
\text { Recent }\end{array}$ & $\begin{array}{l}\text { MLP \& MNHN (original) } \\
\text { MLP \& MNHN (original) }\end{array}$ & Candela 1999 \\
\hline Erethizon & E. dorsatum & & Recent & MNHN (original) & \\
\hline Chaetomys & C. subspinosus & & Recent & MHNG (pictures) & Martin 1994 \\
\hline Chinchilloidea & & & & & \\
\hline Eoincamys & E. ameghinoi & Santa Rosa (Yahuarango $\mathrm{Fm}$.), Peru & ?Late Eocene / Early Oligocene & INGEMMET (holotype) & Frailey and Campbell 2004 \\
\hline & $\begin{array}{l}\text { E. pascuali } \\
\text { Exf }\end{array}$ & 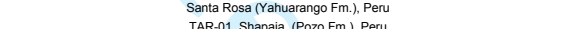 & ?Late Eocene / Early Oligocene & INGEMMET (holotype) & Frailey and Campbell 2004 \\
\hline & E. cf. pascuali & $\begin{array}{l}\text { TAR-01, Shapaja (Pozo Fm.), Peru } \\
\text { TAB.1 }\end{array}$ & $\begin{array}{l}\text { Early Oligocene } \\
\text { Farken }\end{array}$ & MUSM (original) & Boivin et al. 2018 \\
\hline & $\begin{array}{l}\text { E. valuerdei } \\
\text { E.parus }\end{array}$ & 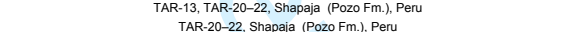 & $\begin{array}{l}\text { Early Oligocene } \\
\text { Eary ligocene }\end{array}$ & MUSM (original) & $\begin{array}{l}\text { Boivin et al. } 2018 \\
\text { Boivineta } 2018\end{array}$ \\
\hline ?Eoincamys & $\begin{array}{l}\text { E. parvis } \\
\text { ?Eoincamys sp. }\end{array}$ & & $\begin{array}{l}\text { Early olgigcoene } \\
\text { Early Oligecene }\end{array}$ & $\begin{array}{l}\text { MUSM (original) } \\
\text { MUSM (orignal) }\end{array}$ & $\begin{array}{l}\text { Boivin et al. } 2018 \\
\text { Boivin ta } 2018\end{array}$ \\
\hline Loncolicu & L. tretos & 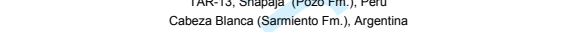 & $\begin{array}{l}\text { Early ilgocene } \\
\text { Late Oligocene }\end{array}$ & $\begin{array}{l}\text { MUSM (orginal) } \\
\text { UM (cast) }\end{array}$ & $\begin{array}{l}\text { Boinu e a. a. } 2018 \\
\text { Vucetich et al. } 2015\end{array}$ \\
\hline Scotamys & S. antiquus & Cabeza Blanca and La Flecha (Sarmiento Fm.), Argentina & Late Oligocene & & Loomis 1914; Wood and Patterson 1959 \\
\hline Incamys & 1. menniorum & Cabeza Blanca (Sarmiento Fm.), Argentina & Late Oligocene & UM (cast) & Vucetich et al. 2015 \\
\hline & 1. bolivianus & Salla (Salla Beds), Bolivia & late Early Oligocene - Late Oligocene & $\begin{array}{l}\text { MNHN-Bol, MNHN \& UM } \\
\text { (original) }\end{array}$ & $\begin{array}{l}\text { Hoffstetter and Lavocat 1970; Lavocat 1976; } \\
\text { Patterson and Wood 1982 }\end{array}$ \\
\hline Chambiramys & C. shipiborum & Contamana CTA-32 (Chambira Fm.), Peru & Late Oligocene & MUSM (original) & Boivin et al. 2017b \\
\hline & C. sylvaticus & Contamana CTA-61 (Chambira Fm.), Peru & Late Oligocene & MUSM (original) & Boivin et al. $2017 \mathrm{~b}$ \\
\hline Maquiamys & M. praecursor & Contamana CTA-61 (Chambira Fm.), Peru & Late Oligocene & MUSM (original) & Boivin et al. 2017b \\
\hline Eoviscaccia & $\begin{array}{l}\text { E. frassinetii } \\
\text { E. bolivina }\end{array}$ & $\begin{array}{l}\text { Tinguiririca Terras as (el Flaco (Abanico omm.), Chile } \\
\text { Lacayani unnamed }\end{array}$ & $\begin{array}{l}\text { Early ligocene } \\
\text { Oligocene - Miocene boundary }\end{array}$ & MNHN Griginal & Wyss et al. 1993; Bertrand et al. 2012 \\
\hline & $\begin{array}{l}\text { E. Domvina } \\
\text { Eastralis }\end{array}$ & & Oligocene - Miocene boundary & MNHN (original) & $\begin{array}{l}\text { Vucetich } 1989 \\
\text { Vucetich 1989: Kucramar 20016- Vuctich et al. }\end{array}$ \\
\hline & E. australis & $\begin{array}{l}\text { Sarmiento } \mathrm{Fm} . \text {., Chichinales } \mathrm{Fm} \text {. and Cerro Banderar Fm. Argentina (for the ist of locallities, see } \\
\text { Vucetich et al. } 2010 \mathrm{~b} \text { ) }\end{array}$ & Early Miocene & MACN (original) & $\begin{array}{l}\text { Vucetich 1989; Kramarz 2001b; Vucetich et al. } \\
2010 \mathrm{~b}\end{array}$ \\
\hline $\begin{array}{l}\text { Garridomys } \\
\text { Scleromys }\end{array}$ & $\begin{array}{l}\text { G. curnunuquem } \\
\text { s. quadrangualus }\end{array}$ & $\begin{array}{l}\text { near Barda Negra (Cerro Bandera Formation), Argentina } \\
\text { Pinturas Fm. (for the list of localities, see Kramarz, 2006), Argentina }\end{array}$ & $\begin{array}{l}\text { Early Miocene } \\
\text { late Early Miocene }\end{array}$ & MACN \& MLP (original) & $\begin{array}{c}\text { Kramarz et al. } 2013 \\
\text { Kramarz } 2006\end{array}$ \\
\hline & s. angustus & Santa Cruz Fm., Argentina & late Early Miocene & MACN (original) & Ameghino 1887 \\
\hline & S. osbomianus & 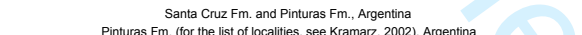 & $\begin{array}{l}\text { late Early Miocene } \\
\text { late Early Miocene }\end{array}$ & MACN (original) & Ameghino 1894; Kramarz 2006 \\
\hline $\begin{array}{l}\text { Perimys } \\
\text { Drytomomys }\end{array}$ & $\begin{array}{l}\text { P. intermedius } \\
\text { D. aequatorialis }\end{array}$ & $\begin{array}{l}\text { Pinturas Fm. (for the list of locallities, see Kramarz, 2002), Argentina } \\
\text { near the hacienda of Serior Carrasco (near Nabon), Equador, La Venta (Villavieja Fm.), Colombia }\end{array}$ & $\begin{array}{l}\text { late Eary Miocene } \\
\text { late Middle Miocene }\end{array}$ & & Anthony 1922; Fields 1957: Walton 1997; \\
\hline Drytomomys & & $\begin{array}{l}\text { near the hacienda of Sentor Carrasco (near Nabon), Equador, La Venta (Villavieja } F \text { m.), Colombla } \\
\text { Ituzaingo Fm. Argentina }\end{array}$ & late Middle Miocene & & Candela and Nasif 2006 \\
\hline Microscleromys & $\begin{array}{l}\text { D. paradousalis } \\
\text { M. }\end{array}$ & $\begin{array}{l}\text { Ituzaingo Fm., Argentina } \\
\text { La Venta (Villavieja Fm.), Colombia }\end{array}$ & $\begin{array}{l}\text { Late Miocene } \\
\text { late Middle Miocene }\end{array}$ & & $\begin{array}{l}\text { Ameghino } 1889 \text { 9 Candela and Nasifi } 2006 \\
\text { Walton 1990, } 1997\end{array}$ \\
\hline & M. cribriphilus & La Venta (Villavieja Fm.), Colombia & late Middle Miocene & & Walton 1990, 1997 \\
\hline Potamarchus & P. murinus & Solimoes Fm. (for the list of localities, see Kerber et al., 2016), Brazil & Late Miocene & & Kerber et al. 2016 \\
\hline Neoepiblema & N. ambrossetianus & Niterói locality (Solimoes Fm.), Brazil & Late Miocene & UFAC (original) & Kerber et al. 2017 \\
\hline & N. horridula & Talismã and Cachoeira do Bandeiro localities (Solimoes Fm.), Brazil & Late Miocene & UFAC (original) & Kerber et al. 2017 \\
\hline Chinchilla & C. lanigera & & Recent & MLP (original) & \\
\hline Lagidium & L. viscacia & & Recent & MLP \& MNHN (original) & \\
\hline $\begin{array}{c}\text { Lagostomus } \\
\text { Dinomys }\end{array}$ & L. maximus & & $\begin{array}{l}\text { Recent } \\
\text { Recent }\end{array}$ & MLP \& MNHN (original) & \\
\hline Cavioidea & D. ordinckil & & & inveriv (orginali) & \\
\hline Andemys & A. termasi & Tinguiririca Termas del Flaco (Abanico Fm.), Chili & Early Oligocene & & Bertrand et al. 2012 \\
\hline Chubutomys & c. simpsoni & Cabeza Blanca, La Flecha, and Punta Nava (Sarmiento Fm.) and Cerro Pico Truncado, Argentina & Late Oligocene & & Wood and Patterson 1959; Pérez et al, 2012, \\
\hline & c. navaensis & Punta Nava (Sarmiento Fm.), Argentina & Late Oligocene & & $\begin{array}{ll}2018 \\
\text { Pêrez et al., } 2012\end{array}$ \\
\hline Branisamys & B. luribayensis & Salla (Salla Beds), Bolivia & late Early Oligocene - Late Oligocene & $\begin{array}{l}\text { MNHN-Bol, MNHN \& UM } \\
\text { (original) }\end{array}$ & $\begin{array}{l}\text { Hoffstetter and Lavocat 1970; Lavocat 1976; } \\
\text { Patterson and Wood 1982 }\end{array}$ \\
\hline Australoprocta & A. fleagei & Bryn Gwyn, Sacanana (Sarmineto Fm.) and Paso Córdoba (Chinchinales Fm.), Argentina & Early Miocene & & Kramarz 1998; Vucetich et al. $2010 \mathrm{~b}$ \\
\hline Neoreomys & N. pinturensis & $\begin{array}{c}\text { Gran Barranca (Sarmiento Fm.) and Carmen Lower and Potezuelo Sumich Norte (Pinturas Fm.), } \\
\text { Argentina }\end{array}$ & Early Miocene & & Kramarz 2006; Kramarz et al. 2010 \\
\hline & N. australis & $\begin{array}{l}\text { Santa Cruz Fm. and Pinturas Fm. (for the list of localities, see Kramarz 2006), Argentina; Pampa } \\
\text { Castillo (unnamed Fm.), Chile }\end{array}$ & late Early Miocene & MACN \& MLP (original) & $\begin{array}{l}\text { Ameghino 1887; Flynn et al. 2002; Kramarz } \\
2006 \text {; Candela et al. 2012; Kay et al. 2012 }\end{array}$ \\
\hline Luantus & L. propheticus & Pinturas Fm. (for the list of locallities, see Kramarz, 2006), Argentina & late Early Miocene & & Kramarz 2006 \\
\hline Dasyprocta & D. sp. & & Recent & MLP \& UM (original) & \\
\hline Cuniculus & c. paca & & Recent & UM (original) & \\
\hline & C. taczanowskii & & Recent & UM (origin & \\
\hline Cavia & C. aperea & & Recent & MLP (original) & \\
\hline Galea & G.sf & & Recent & MNHN (original) & \\
\hline $\begin{array}{l}\text { Dolichotis } \\
\text { Hydrocheerus }\end{array}$ & $\begin{array}{l}\text { D. patagonum } \\
\text { H hudrechaeris }\end{array}$ & & $\begin{array}{l}\text { Recent } \\
\text { Recent }\end{array}$ & $\begin{array}{l}\text { UM (original) } \\
\text { MP }\end{array}$ & \\
\hline Hydrochoerus & H. hydrochaeris & & Recent & MLP \& MNHN (original) & \\
\hline sedis extinct sup & & & & & \\
\hline Litodontomys & L. chubutomys & Cabeza Blanca (Sarmiento Fm.), Argentina & & & \\
\hline Cephalomys & & & & MNHN (original) & Ameghino 1897; Wood and Patterson 1959 \\
\hline & $\begin{array}{l}\text { C. plexus } \\
\text { C. ceciae }\end{array}$ & $\begin{array}{l}\text { Cabeza Blanca and La Flecha (Sarmiento Fm.), Argentina } \\
\text { Cabeza Blanca (Sarmiento Fm.), Argentina }\end{array}$ & $\begin{array}{l}\text { Late Oligocene } \\
\text { Late Oligocene }\end{array}$ & UM (cast) & Ameghino 1897; Wood and Patterson 1959 \\
\hline & & & Late Oligocene & UM (cast) & $\begin{array}{l}\text { Vucetich et al. } 2015 \\
\text { Ameghing }\end{array}$ \\
\hline Asteromys & A. punctus & Cabeza Blanca, Laguna de los Machos, and Punta Nava (Sarmiento Fm.), Argentina & Late Oligocenene & MACN (original) & $\begin{array}{l}\text { Pimeregino and Vucetich 2012; Pérez et al. } 2018 \text {; } \\
\text { Pêrez }\end{array}$ \\
\hline "Asteromys" & "A." bolivianus & Salla (Salla Beds), Bolivia & late Early Oligocene - Late Oligocene & $\begin{array}{l}\text { MNHN-Bol, MNHN \& UM L } \\
\text { (original) }\end{array}$ & $\begin{array}{l}\text { Lavocat 1976; Patterson and Wood 1982; Perez } \\
\text { et al. } 2018 \text {. }\end{array}$ \\
\hline Banderomys & B. leanzai & Cerro Bandera Fm. and La Estrella (Sarmiento Fm.), Argentina & Early Miocene & & Kramarz 2005; Busker et al. 2017 \\
\hline Soriamys & $\begin{array}{l}\text { S. gaimanensis } \\
\text { S. ganganensis }\end{array}$ & $\begin{array}{l}\text { Bryn Gwyn (Sarmiento Fm.), Argentina } \\
\text { Pampa de Gan Gan/Sacanana (Sarmiento Fm.). Argentina }\end{array}$ & $\begin{array}{l}\text { Early Miocene } \\
\text { Early Miocene }\end{array}$ & & $\begin{array}{l}\text { Kramarz 2001c; Vucetich et al. 2010b } \\
\text { Kramarz 2001c; Vucetich et al. 2010b }\end{array}$ \\
\hline
\end{tabular}




\title{
References:
}

\begin{abstract}
Ameghino F. 1887. Enumeración sistematica de las especies de mamíferos fósiles coleccionados por Carlos Ameghino en los terrenos eocenos de Patagonia austral y depositados en el museo de La Plata. Bol Mus La Plata. 1:1-26.
\end{abstract}

Ameghino F. 1889. Contribución al conocimiento de los mamíferos fósiles de la República Argentina. Bol. Acad. nac. cienc. 6:1-1027.

Ameghino F. 1894. Énumération synoptique des espèces de mammifères fossiles des formations éocènes de Patagonie. Bol. Acad. nac. cienc. 13:259-455.

Ameghino F. 1897. Mamiferos Cretaceos de la Argentina. Segunda contribucion al conocimiento de la fauna mastologica de las capas con restos de Pyrotherium. Bol acad arg. $18: 406-521$.

Ameghino F. 1902. Première contribution à la connaissance de la faune mammalogique des couches à Colpodon. Bol. Acad. nac. cienc. 17:71-138.

Ameghino F. 1903. Los diprotodontes del orden de los plagiaulacoideos y el origen de los roedores y de los polimastodontes. Ann Mus Nac Hist Nat Buenos Aires. 9:81-192.

Ameghino F. 1904. Nuevas especies de mamíferos cretáceos y terciarios de la República Argentina. A Soc Cien Arg. 58:35-41, 56-71, 182-192, 225-292.

Anthony HE. 1922. A new fossil rodent from Ecuador. Am Mus Novit. 35:1-4.

Antoine P-O, Marivaux L, Croft DA, Billet G, Ganerød M, Jaramillo C, Martin T, Orliac MJ, Tejada-Lara J, Altamirano AJ, Duranthon F, Fanjat G, Rousse S, Salas-Gismondi R. 2012. 
Middle Eocene rodents from Peruvian Amazonia reveal the pattern and timing of caviomorph origins and biogeography. Proc. R. Soc. B. 279:1319-1326.

Antoine P-O, Roddaz M, Brichau S, Tejada-Lara J, Salas-Gismondi R, Altamirano AJ, Louterbach M, Lambs L, Otto T, Brusset S. 2013. Middle Miocene vertebrates from the Amazonian Madre de Dios Subandean Zone, Perú. J S Am Earth Sci. 42:91-102.

Arnal M, Kramarz AG. 2011. First complete skull of an octodontoid (Rodentia, Caviomorpha) from the Early Miocene of South America and its bearing in the early evolution of Octodontoidea. Geobios. 44:435-444.

Arnal M, Pérez ME. 2013. A new acaremyid rodent (Hystricognathi: Octodontoidea) from the Middle Miocene of Patagonia (South America) and considerations on the early evolution of Octodontoidea. Zootaxa. 3616:119-34.

Arnal M, Vucetich MG. 2011. First record of supernumerary teeth in South American fossil rodents. J Vert Paleontol. 31:925-927.

Arnal M, Vucetich MG. 2015. Revision of the fossil rodent Acaremys Ameghino, 1887 (Hystricognathi, Octodontoidea, Acaremyidae) from the Miocene of Patagonia (Argentina) and the description of a new acaremyid. Hist Biol. 27:42-59.

Arnal M, Kramarz AG, Vucetich MG, Vieytes EC. 2014. A new early Miocene octodontoid rodent (Hystricognathi, Caviomorpha) from Patagonia (Argentina) and a reassessment of the early evolution of Octodontoidea. J Vert Paleontol. 34:397-406.

Arnal M, Vucetich MG, Croft DA, Bargo MS, Fernicola JC, Vizcaíno SF. 2017. Systematic revision and evolutionary history of Acarechimys Patterson in Kraglievich, 1965 (Rodentia, Caviomorpha, Octodontoidea). Ameghiniana. 54:307-330. 
Bertrand OC, Flynn JJ, Croft DA, Wyss AR. 2012. Two new taxa (Caviomorpha, Rodentia) from the Early Oligocene Tinguiririca fauna (Chile). Am Mus Novit. (3750):1-36.

Boivin M, Marivaux L, Orliac MJ, Pujos F, Salas-Gismondi R, Tejada-Lara JV, Antoine P-O. 2017a. Late middle Eocene caviomorph rodents from Contamana, Peruvian Amazonia. Palaeontol Electron. 20.1.19A:1-50.

Boivin M, Marivaux L, Candela AM, Orliac MJ, Pujos F, Salas-Gismondi R, Tejada-Lara JV, Antoine P-O. 2017b. Late Oligocene caviomorph rodents from Contamana, Peruvian Amazonia. Pap Palaeontol. 3:69-109.

Boivin M, Marivaux L, Pujos F, Salas-Gismondi R, Tejada-Lara JV, Varas-Malca R, Antoine P-O. 2018. Early Oligocene caviomorph rodents from Shapaja, Peruvian Amazonia.

Palaeontogr Abt A. 311. DOI: 10.1127/pala/2018/0075.

Bordas AF. 1939. Diagnosis sobre algunos mamíferos de las capas con Colpodon. Physis. $14: 413-433$.

Bruijn H de, Ünay E, Saraç G, Yïlmaz A. 2003. A rodent assemblage from the Eo/Oligocene boundary interval near Süngülü, Lesser Caucasus, Turkey. In: López-Martínez N, PeláezCampomanes P, Henández Fernández M, editors. Coloquios de Paleontologia. En honor al Dr. Remmert Daams. Surrounding fossil mammals: dating, evolution and paleoenvirontment). Madrid: Facultad de Ciencias Geologicas Departamento de Paleontologia; p. 47-76.

Busker F, Pérez ME, Krause JM, Vucetich MG. 2017. First record of Banderomys leanzai Kramarz, 2005 (Rodentia, Caviomorpha) in Chubut Province, Patagonia (Argentina). Rev Mus Argent Cienc Nat. 19 nueva serie:121-129. 
Candela AM. 1999. The evolution of the molar pattern of the Erethizontidae (Rodentia, Hystricognathi) and the validity of Parasteiromys Ameghino, 1904. Palaeovertebrata 28:5373.

Candela AM. 2000. Los Erethizontidae (Rodentia, Hystricognathi) fósiles de Argentina. Sistemática e historia evolutiva y biogeográfica. Unpublished PhD thesis, Universidad Nacional de La Plata.

Candela AM. 2002. Lower deciduous tooth homologies in Erethizontidae [Rodentia, Hystricognathi]: evolutionary significance. Acta Palaeontol Pol. 47:717-723.

Candela AM. 2003. A new porcupine (Rodentia, Erethizontidae) from the Early and Middle Miocene of Patagonia. Ameghiniana. 40:483-494.

Candela AM. 2004. A New Giant Porcupine (Rodentia, Erethizontidae) from the Late Miocene of Argentina. J Vert Paleontol. 24:732-741.

Candela AM, Nasif NL. 2006. Systematics and biogeographic significance of Drytomomys typicus (Scalabrini in Ameghino, 1889) nov. comb., a Miocene Dinomyidae (Rodentia, Hystricognathi) from Northeast of Argentina. Neues Jahrb Geol Paläontol. 3:165-181.

Candela AM, Vucetich MG. 2002. Hypsosteiromys (Rodentia, Hystricognathi) from the Early Miocene of Patagonia (Argentina), the only Erethizontidae with a tendency to hypsodonty. Geobios. 35:153-161.

Candela AM, Rasia LL, Pérez ME. 2012. Early Miocene Paleobiology in Patagonia: Paleobiology of Santacrucian caviomorph rodents: a morphofunctional approach. In: Vizcaíno SF, Kay RF, Bargo MS, editors. Early Miocene Paleobiology in Patagonia. Cambridge: Cambridge University Press, p. 287-305. 
Coster PMC, Beard KC, Salem MJ, Chaimanee Y, Brunet M, Jaeger J-J. 2015. A new early

Oligocene mammal fauna from the Sirt Basin, central Libya: biostratigraphic and paleobiogeographic implications. J Afr Earth Sci. 104:43-55.

Croft DA, Chick JM, Anaya F. 2011. New Middle Miocene caviomorph rodents from Quebrada Honda, Bolivia. J Mamm Evol. 18:245-268.

Dawson MR, Li C-K, Qi T. 1984. Eocene ctenodactyloid rodents (Mammalia) of eastern central Asia. Ann Carnegie Mus. 9 Special Publication:138-150.

Fields RW. 1957. Hystricomorph rodents from the Late Miocene of Colombia, South America. Univ Calif publ geol. 32:273-404.

Flynn JJ, Jacobs LL, Cheema IU. 1986. Baluchimyinae, a new ctenodactyloid rodent subfamily from the Miocene of Baluchistan. Am Mus Novit. 2841:1-58.

Flynn JJ, Novacek MJ, Dodson HE, Frassinetti D, Mckenna MC, Norell MA, Sears KE, Swisher CC III, Wyss AR. 2002. A new fossil mammal assemblage from the southern Chilean Andes: implications for geology, geochronology, and tectonics. J S Am Earth Sci. 15:285302.

Frailey CD, Campbell KE. 2004. Paleogene rodents from Amazonian Peru: the Santa Rosa local fauna. In: Campbell KE, editor. The Paleogene Mammalian Fauna of Santa Rosa, Amazonian Peru. Natural History Museum of Los Angeles County, Science Series 40; p. 71130.

Jaeger J-J, Denys C, Coiffait B. 1985. New Phiomorpha and Anomaluridae from the late Eocene of North-West Africa: phylogenetic implications. In: Luckett WP, Hartenberger J-L, 
editors. Evolutionary Relationships among Rodents, a Multidisciplinary Analysis. New York: Springer US; p. 567-588.

Jaeger J-J, Marivaux L, Salem M, Bilal AA, Chaimanee Y, Marandat B, Valentin X, Duringer P, Schuster M, Benammi M, Métais E, Brunet M. 2010. New rodent assemblages from the Eocene Dur at-Talah escarpment (Sahara of Central Libya): systematic, biochronologic and paleobiogeographic implications. Zool J Linn Soc. 160:195-213.

Hoffstetter R, Lavocat R. 1970. Découverte dans le Déséadien de Bolivie des genres pentalophodontes appuyant les affinités africaines des rongeurs caviomorphes. C R Acad Sci. 271:172-175.

Hussain ST, Bruijn H de, Leinders JM. 1978. Middle Eocene Rodents from the Kala Chitta Range (Punjab, Pakistan). Palaeontology. 81:101-112.

Kay BRF, Vizcaíno SF, Bargo MS. 2012. A review of the paleoenvironment and paleoecology of the Miocene Santa Cruz Formation. In: Vizcaíno SF, Kay RF, Bargo MS, editors. Early Miocene Paleobiology in Patagonia. Cambridge: Cambridge University Press; p. $331-365$.

Kerber L, Mayer EL, Ribeiro AM, Vucetich MG. 2016. Late Quaternary caviomorph rodents (Rodentia: Hystricognathi) from the Serra da Capivara, northeastern Brazil, with description of a new taxon. Hist Biol. 28:439-458.

Kerber L, Negri FR, Ribeiro AM, Nasif N, Souza-Filho JP, Ferigolo J. 2017. Tropical fossil caviomorph rodents from the southwestern Brazilian Amazonia in the context of the South American faunas: systematics, biochronology, and paleobiogeography. J Mamm Evol. 24:5770. 


\begin{abstract}
Kramarz AG. 1998. Un nuevo dasyproctidae (Rodentia, Caviomorpha) del Mioceno inferior de Patagonia. Ameghiniana. 35:181-192.
\end{abstract}

Kramarz AG. 2001a. Un nuevo roedor Adelphomyinae (Hystricognathi, Echimyidae) del Mioceno Medio-Inferior de Patagonia, Argentina. Ameghiniana. 38:163-168.

Kramarz AG. 2001b. Registro de Eoviscaccia (Rodentia, Chinchillidae) en estratos colhuehuapenses de Patagonia, Argentina. Ameghiniana. 38:237-242.

Kramarz AG. 2001c. Revision of the family Cephalomyidae (Rodentia, Caviomorpha) and new cephalomyids from the Early Miocene of Patagonia. Palaeovertebrata. 30:51-88.

Kramarz AG. 2004. Octodontoids and erethizontoids (Rodentia, Hystricognathi) from the Pinturas Formation, Early-Middle Miocene of Patagonia, Argentina. Ameghiniana. 41:199216.

Kramarz AG. 2005. A primitive cephalomyid hystricognath rodent from the early Miocene of northern Patagonia, Argentina. Acta Palaeontol Pol. 50:249-258.

Kramarz AG. 2006. Neoreomys and Scleromys (Rodentia, Hystricognathi) from the Pinturas Formation, late Early Miocene of Patagonia, Argentina. Rev Mus Argent Cienc Nat. 8:53-62. Kramarz AG, Vucetich MG, Carlini AA, Ciancio MR, Abello MA, Deschamp CM, Gelfo JN. 2010. A new fauna at the top of the Gran Barranca sequence and its biochronological significance. In: Madden RH, Carlini AA, Vucetich MG, Kay RF, editors. The Paleontology of Gran Barranca, Evolution and Environmental Change through the Middle Cenozoic of Patagonia. Cambridge: Cambridge University Press; p. 264-277. 
Kramarz AG, Vucetich MG, Arnal M. 2013. A new Early Miocene chinchilloid hystricognath rodent; an approach to the understanding of the early chinchillid dental evolution. J Mamm Evol. 20:249-261.

Lavocat R. 1973. Les rongeurs du Miocène d'Afrique orientale. 1. Miocène inférieur. Mémoires et Travaux E.P.H.E. de l'Institut de Montpellier.

Lavocat R. 1976. Rongeurs caviomorphes de l'Oligocène de Bolivie. Rongeurs du bassin déséadien de Salla. Palaeovertebrata. 7:15-90.

Leidy J. 1871. Notice of some extinct rodents. Proc Acad Nat Sci Phila. 22:230-232.

Li CK, Zheng JJ, Ting S. Y. 1989. The skull of Cocomys linchaensis, an early Eocene ctenodactyloid rodent of Asia. In: Black CC, Dawson MR, editors. Papers on Fossil Rodents, in honor of Albert Elmer Wood. Los Angeles: Natural History Museum; p. 179-192.

Loomis FB. 1914. The Deseado Formation of Patagonia. New Hampshire: Rumford Press, Concord.

Marivaux L, Welcomme J-L. 2003. New diatomyid and baluchimyine rodents from the Oligocene of Pakistan (Bugti Hills, Balochistan): systematic and paleobiogeographic implications. J Vert Paleontol. 23:420-434.

Marivaux L, Benammi M, Ducrocq S, Jaeger J-J, Chaimanee Y. 2000. A new baluchimyine rodent from the Late Eocene of the Krabi Basin (Thailand): palaeobiogeographic and biochronologic implications. C R Acad Sci. 331:427-433.

Marivaux L, Welcomme J-L, Vianey-Liaud M, Jaeger J-J. 2002. The role of Asia in the origin and diversification of hystricognathous rodents. Zool Scr. 31:225-239. 
Martin T. 1994. On the systematic position of Chaetomys subspinosus (Rodentia:

Caviomorpha) based on evidence from the incisor enamel microstructure. J Mamm Evol. 2:117-131.

Meng J, Wyss AR. 2001. The morphology of Tribosphenomys (Rodentiaformes, Mammalia): phylogenetic implications for basal Glires. J Mamm Evol. 8:1-71.

Meng J, Li C, Beard KC, Gebo DL, Wang Y, Wang H. 2007a. New material of Alagomyidae (Mammalia, Glires) from the late Paleocene Subeng Locality, Inner Mongolia. Am Mus Novit. (3597):1-29.

Meng J, Li C, Ni X, Wang Y, Beard KC. 2007b. A new Eocene rodent from the Lower Arshanto Formation in the Nuhetingboerhe (Camp Margetts) area, Inner Mongolia. Am Mus Novit. (3569):1-18.

Patterson B, Pascual R. 1968. New echimyid rodents from the Oligocene of Patagonia, and a synopsis of the family. Breviora. 301:1-14.

Patterson B, Wood AE. 1982. Rodents from the Deseadan Oligocene of Bolivia and the relationships of the Caviomorpha. Bull Mus Comp Zool. 149:371-543.

Pérez ME, Vucetich MG. 2012. Asteromys punctus Ameghino (Rodentia, Hystricognathi, Cavioidea) from the Late Oligocene of Patagonia (Argentina) and the early evolution of Cavioidea sensu stricto. Ameghiniana. 49:118-125.

Pérez ME, Krause M, Vucetich MG. 2012. A new species of Chubutomys (Rodentia, Hystricognathi) from the late Oligocene of Patagonia and its implications on the early evolutionary history of Cavioidea sensu stricto. Geobios. 45:573-580. 
Pérez ME, Arnal M, Boivin M, Vucetich MG, Candela A, Busker F, Mamani Quispe B. New caviomorph rodents from the Late Oligocene of Salla, Bolivia: taxonomic, chronological, and biogeographic implications in the Deseadan faunas of South America. J Syst Palaeontol. DOI: 10.1080/14772019.2018.1471622.

Sallam HM, Seiffert ER, Steiper ME, Simons EL. 2009. Fossil and molecular evidence constrain scenarios for the early evolutionary and biogeographic history of hystricognathous rodents. Proc Natl Acad Sci USA. 106:16722-16727.

Sallam HM, Seiffert ER, Simons EL. 2011. Craniodental morphology and systematics of a new family of hystricognathous rodents (Gaudeamuridae) from the Late Eocene and Early Oligocene of Egypt. PLoS One. 6, e16525.

Sallam HM, Seiffert ER, Simons EL. 2012. A basal phiomorph (Rodentia, Hystricognathi) from the Late Eocene of the Fayum Depression, Egypt. Swiss J Palaeontol. 131:283-301.

Shockey BJ, Salas-Gismondi R, Gans PB, Jeong A, Flynn JJ. 2009. Paleontology and geochronology of the Deseadan (late Oligocene) of Moquegua, Peru. Am Mus Novit. (3668):1-24.

Vucetich MG. 1989. Rodents (Mammalia) of the Lacayani fauna revisited (Deseadan, Bolivia). Comparison with new Chinchillidae and Cephalomyidae from Argentina. Bull. Mus. Natl. Hist. Nat. Paris, 4:233-247.

Vucetich MG, Bond M. 1984. Un nuevo Octodontoidea (Rodentia, Caviomorpha) del Oligoceno tardío de la provincia de Chubut (Argentina). Ameghiniana. 21:105-114. 
Vucetich MG, Kramarz AG. 2003. New Miocene rodents of Patagonia (Argentina) and their bearing in the early radiation of the octodontoids (Hystricognathi). J Vert Paleontol. 23:435444.

Vucetich MG, Ribeiro AM. 2003. A new and primitive rodent from the Tremembé Formation (Late Oligocene) of Brazil, with comments on the morphology of the lower premolars of caviomorph rodents. Rev Bras Paleontolog. 5:73-82.

Vucetich MG, Verzi DH. 1991. Un nuevo Echimyidae (Rodentia, Hystricognathi) de la edad Colhuehuapense de Patagonia y consideraciones sobre la sistemática de la familia.

Ameghiniana. 28:67-74.

Vucetich MG, Verzi DH. 1994. Las homologías en los diseños oclusales de los roedores Caviomorpha: un modelo alternativo. Mastozool neotrop. 1:61-72.

Vucetich MG, Verzi DH. 1996. A peculiar octodontoid (Rodentia, Caviomorpha) with terraced molars from the Lower Miocene of Patagonia (Argentina). J Vert Paleontol. 16:297302.

Vucetich MG, Vieytes EC. 2006. A Middle Miocene primitive octodontoid rodent and its bearing on the early evolutionary history of the Octodontoidea. Palaeontogr Abt A. 27:81-91.

Vucetich MG, Verzi DH, Dozo MT. 1992. El ‘status’ sistemático de Gaimanomys alwinea (Rodentia, Caviomorpha, Echimyidae). Ameghiniana. 29:85-86.

Vucetich MG, Souza Cunha FL de, Alvarenga HMF de. 1993a. Un Roedor Caviomorpha de la Formación Tremembé (Cuenca de Taubaté), Estado de Sao Paulo, Brasil. An Acad Bras Ciênc. 65:247-251. 
Vucetich MG, Mazzoni MM, Pardiñas UFJ. 1993b. Los roedores de la Formación Collón Cura (Mioceno Medio), y la ignimbrita Pilcaniyeu. Cañadón del Tordillo, Neuquen. Ameghiniana. 30:361-381.

Vucetich MG, Vieytes EC, Pérez ME, Carlini AA. 2010a. The rodents from La Cantera and the early evolution of caviomorphs in South America. In: Madden RH, Carlini AA, Vucetich MG, Kay RF, editors. The Paleontology of Gran Barranca, Evolution and Environmental Change through the Middle Cenozoic of Patagonia. Cambridge: Cambridge University Press; p. 189-201.

Vucetich MG, Kramarz AG, Candela AM. 2010b. Colhuehuapian rodents from Gran Barranca and other Patagonian localities: the state of the art. In: Madden RH, Carlini AA, Vucetich MG, Kay RF, editors. The Paleontology of Gran Barranca, Evolution and Environmental Change through the Middle Cenozoic of Patagonia. Cambridge: Cambridge University Press; p. 206-219.

Vucetich MG, Dozo MT, Arnal M, Pérez ME. 2015. New rodents (Mammalia) from the Late Oligocene of Cabeza Blanca (Chubut) and the first rodent radiation in Patagonia. Hist Biol. $27: 236-257$.

Walton AH. 1990. Rodents of the La Venta Fauna, Miocene, Colombia: biostratigraphy and paleoenvironmental implications. Unpublished Ph.D. Thesis, Southern Methodist University, Dallas, USA.

Walton AH. 1997. Rodents. In: Kay RF, Madden RH, Cifelli RL, Flynn JJ, editors. Vertebrate paleontology in the Neotropics. The Miocene Fauna of La Venta, Colombia. Washington and London: Smithsonian Institution Press; p. 392-409. 
Wood AE. 1949. A new Oligocene rodent genus from Patagonia. Am Mus Novit. (1435):154.

Wood AE. 1962. The early Tertiary rodents of the family Paramyidae. Trans Am Philos Soc. 52:1-261.

Wood AE. 1968. Early Cenozoic mammalian faunas, Fayum Province, Egypt, Part II: the African Oligocene Rodentia. Peabody Mus Nat Hist. 28:23-105.

Wood AE, Patterson B. 1959. The rodents of the Deseadan Oligocene of Patagonia and the beginnings of South American rodent evolution. Bull Mus Comp Zool. 120:281-428.

Wyss AR, Flynn JJ, Norell MA, Swisher CC III, Charrier R, Novacek MJ, McKenna MC. 1993. South America's earliest rodent and recognition of a new interval of mammalian evolution. Nature. 365:434-437. 


\section{Supplemental Online Material}

Caviomorph taxa used for comparisons in this study. 


\section{References:}

Ameghino F. 1887. Enumeración sistematica de las especies de mamíferos fósiles coleccionados por Carlos Ameghino en los terrenos eocenos de Patagonia austral y depositados en el museo de La Plata. Bol Mus La Plata. 1:1-26.

Ameghino F. 1889. Contribución al conocimiento de los mamíferos fósiles de la República Argentina. Bol. Acad. nac. cienc. 6:1-1027.

Ameghino F. 1894. Énumération synoptique des espèces de mammifères fossiles des formations éocènes de Patagonie. Bol. Acad. nac. cienc. 13:259-455.

Ameghino F. 1897. Mamiferos Cretaceos de la Argentina. Segunda contribucion al conocimiento de la fauna mastologica de las capas con restos de Pyrotherium. Bol acad arg. 18:406-521.

Ameghino F. 1902. Première contribution à la connaissance de la faune mammalogique des couches à Colpodon. Bol. Acad. nac. cienc. 17:71-138.

Ameghino F. 1903. Los diprotodontes del orden de los plagiaulacoideos y el origen de los roedores y de los polimastodontes. Ann Mus Nac Hist Nat Buenos Aires. 9:81-192.

Ameghino F. 1904. Nuevas especies de mamíferos cretáceos y terciarios de la República Argentina. A Soc Cien Arg. 58:35-41, 56-71, 182-192, 225-292.

Anthony HE. 1922. A new fossil rodent from Ecuador. Am Mus Novit. 35:1-4.

Antoine P-O, Marivaux L, Croft DA, Billet G, Ganerød M, Jaramillo C, Martin T, Orliac MJ, Tejada-Lara J, Altamirano AJ, Duranthon F, Fanjat G, Rousse S, Salas-Gismondi R. 2012. 
Middle Eocene rodents from Peruvian Amazonia reveal the pattern and timing of caviomorph origins and biogeography. Proc. R. Soc. B. 279:1319-1326.

Antoine P-O, Roddaz M, Brichau S, Tejada-Lara J, Salas-Gismondi R, Altamirano AJ, Louterbach M, Lambs L, Otto T, Brusset S. 2013. Middle Miocene vertebrates from the Amazonian Madre de Dios Subandean Zone, Perú. J S Am Earth Sci. 42:91-102.

Arnal M, Kramarz AG. 2011. First complete skull of an octodontoid (Rodentia, Caviomorpha) from the Early Miocene of South America and its bearing in the early evolution of Octodontoidea. Geobios. 44:435-444.

Arnal M, Pérez ME. 2013. A new acaremyid rodent (Hystricognathi: Octodontoidea) from the Middle Miocene of Patagonia (South America) and considerations on the early evolution of Octodontoidea. Zootaxa. 3616:119-34.

Arnal M, Vucetich MG. 2011. First record of supernumerary teeth in South American fossil rodents. J Vert Paleontol. 31:925-927.

Arnal M, Vucetich MG. 2015. Revision of the fossil rodent Acaremys Ameghino, 1887 (Hystricognathi, Octodontoidea, Acaremyidae) from the Miocene of Patagonia (Argentina) and the description of a new acaremyid. Hist Biol. 27:42-59.

Arnal M, Kramarz AG, Vucetich MG, Vieytes EC. 2014. A new early Miocene octodontoid rodent (Hystricognathi, Caviomorpha) from Patagonia (Argentina) and a reassessment of the early evolution of Octodontoidea. J Vert Paleontol. 34:397-406.

Arnal M, Vucetich MG, Croft DA, Bargo MS, Fernicola JC, Vizcaíno SF. 2017. Systematic revision and evolutionary history of Acarechimys Patterson in Kraglievich, 1965 (Rodentia, Caviomorpha, Octodontoidea). Ameghiniana. 54:307-330. 


\begin{abstract}
Bertrand OC, Flynn JJ, Croft DA, Wyss AR. 2012. Two new taxa (Caviomorpha, Rodentia) from the Early Oligocene Tinguiririca fauna (Chile). Am Mus Novit. (3750):1-36.
\end{abstract}

Boivin M, Marivaux L, Orliac MJ, Pujos F, Salas-Gismondi R, Tejada-Lara JV, Antoine P-O. 2017a. Late middle Eocene caviomorph rodents from Contamana, Peruvian Amazonia. Palaeontol Electron. 20.1.19A:1-50.

Boivin M, Marivaux L, Candela AM, Orliac MJ, Pujos F, Salas-Gismondi R, Tejada-Lara JV, Antoine P-O. 2017b. Late Oligocene caviomorph rodents from Contamana, Peruvian Amazonia. Pap Palaeontol. 3:69-109.

Boivin M, Marivaux L, Pujos F, Salas-Gismondi R, Tejada-Lara JV, Varas-Malca R, Antoine P-O. 2018. Early Oligocene caviomorph rodents from Shapaja, Peruvian Amazonia.

Palaeontogr Abt A. 311. DOI: 10.1127/pala/2018/0075.

Bordas AF. 1939. Diagnosis sobre algunos mamíferos de las capas con Colpodon. Physis. 14:413-433.

Bruijn H de, Ünay E, Saraç G, Yïlmaz A. 2003. A rodent assemblage from the Eo/Oligocene boundary interval near Süngülü, Lesser Caucasus, Turkey. In: López-Martínez N, PeláezCampomanes P, Henández Fernández M, editors. Coloquios de Paleontologia. En honor al Dr. Remmert Daams. Surrounding fossil mammals: dating, evolution and paleoenvirontment). Madrid: Facultad de Ciencias Geologicas Departamento de Paleontologia; p. 47-76.

Busker F, Pérez ME, Krause JM, Vucetich MG. 2017. First record of Banderomys leanzai Kramarz, 2005 (Rodentia, Caviomorpha) in Chubut Province, Patagonia (Argentina). Rev Mus Argent Cienc Nat. 19 nueva serie:121-129. 
Candela AM. 1999. The evolution of the molar pattern of the Erethizontidae (Rodentia, Hystricognathi) and the validity of Parasteiromys Ameghino, 1904. Palaeovertebrata 28:5373.

Candela AM. 2000. Los Erethizontidae (Rodentia, Hystricognathi) fósiles de Argentina. Sistemática e historia evolutiva y biogeográfica. Unpublished $\mathrm{PhD}$ thesis, Universidad Nacional de La Plata.

Candela AM. 2002. Lower deciduous tooth homologies in Erethizontidae [Rodentia, Hystricognathi]: evolutionary significance. Acta Palaeontol Pol. 47:717-723.

Candela AM. 2003. A new porcupine (Rodentia, Erethizontidae) from the Early and Middle Miocene of Patagonia. Ameghiniana. 40:483-494.

Candela AM. 2004. A New Giant Porcupine (Rodentia, Erethizontidae) from the Late Miocene of Argentina. J Vert Paleontol. 24:732-741.

Candela AM, Nasif NL. 2006. Systematics and biogeographic significance of Drytomomys typicus (Scalabrini in Ameghino, 1889) nov. comb., a Miocene Dinomyidae (Rodentia, Hystricognathi) from Northeast of Argentina. Neues Jahrb Geol Paläontol. 3:165-181.

Candela AM, Vucetich MG. 2002. Hypsosteiromys (Rodentia, Hystricognathi) from the Early Miocene of Patagonia (Argentina), the only Erethizontidae with a tendency to hypsodonty. Geobios. 35:153-161.

Candela AM, Rasia LL, Pérez ME. 2012. Early Miocene Paleobiology in Patagonia: Paleobiology of Santacrucian caviomorph rodents: a morphofunctional approach. In: Vizcaíno SF, Kay RF, Bargo MS, editors. Early Miocene Paleobiology in Patagonia. Cambridge: Cambridge University Press, p. 287-305. 
Coster PMC, Beard KC, Salem MJ, Chaimanee Y, Brunet M, Jaeger J-J. 2015. A new early

Oligocene mammal fauna from the Sirt Basin, central Libya: biostratigraphic and paleobiogeographic implications. J Afr Earth Sci. 104:43-55.

Croft DA, Chick JM, Anaya F. 2011. New Middle Miocene caviomorph rodents from Quebrada Honda, Bolivia. J Mamm Evol. 18:245-268.

Dawson MR, Li C-K, Qi T. 1984. Eocene ctenodactyloid rodents (Mammalia) of eastern central Asia. Ann Carnegie Mus. 9 Special Publication:138-150.

Fields RW. 1957. Hystricomorph rodents from the Late Miocene of Colombia, South America. Univ Calif publ geol. 32:273-404.

Flynn JJ, Jacobs LL, Cheema IU. 1986. Baluchimyinae, a new ctenodactyloid rodent subfamily from the Miocene of Baluchistan. Am Mus Novit. 2841:1-58.

Flynn JJ, Novacek MJ, Dodson HE, Frassinetti D, Mckenna MC, Norell MA, Sears KE, Swisher CC III, Wyss AR. 2002. A new fossil mammal assemblage from the southern Chilean Andes: implications for geology, geochronology, and tectonics. J S Am Earth Sci. 15:285302.

Frailey CD, Campbell KE. 2004. Paleogene rodents from Amazonian Peru: the Santa Rosa local fauna. In: Campbell KE, editor. The Paleogene Mammalian Fauna of Santa Rosa, Amazonian Peru. Natural History Museum of Los Angeles County, Science Series 40; p. $71-$ 130.

Jaeger J-J, Denys C, Coiffait B. 1985. New Phiomorpha and Anomaluridae from the late Eocene of North-West Africa: phylogenetic implications. In: Luckett WP, Hartenberger J-L, 
editors. Evolutionary Relationships among Rodents, a Multidisciplinary Analysis. New York: Springer US; p. 567-588.

Jaeger J-J, Marivaux L, Salem M, Bilal AA, Chaimanee Y, Marandat B, Valentin X, Duringer P, Schuster M, Benammi M, Métais E, Brunet M. 2010. New rodent assemblages from the Eocene Dur at-Talah escarpment (Sahara of Central Libya): systematic, biochronologic and paleobiogeographic implications. Zool J Linn Soc. 160:195-213.

Hoffstetter R, Lavocat R. 1970. Découverte dans le Déséadien de Bolivie des genres pentalophodontes appuyant les affinités africaines des rongeurs caviomorphes. C R Acad Sci. $271: 172-175$.

Hussain ST, Bruijn H de, Leinders JM. 1978. Middle Eocene Rodents from the Kala Chitta Range (Punjab, Pakistan). Palaeontology. 81:101-112.

Kay BRF, Vizcaíno SF, Bargo MS. 2012. A review of the paleoenvironment and paleoecology of the Miocene Santa Cruz Formation. In: Vizcaíno SF, Kay RF, Bargo MS, editors. Early Miocene Paleobiology in Patagonia. Cambridge: Cambridge University Press; p. $331-365$.

Kerber L, Mayer EL, Ribeiro AM, Vucetich MG. 2016. Late Quaternary caviomorph rodents (Rodentia: Hystricognathi) from the Serra da Capivara, northeastern Brazil, with description of a new taxon. Hist Biol. 28:439-458.

Kerber L, Negri FR, Ribeiro AM, Nasif N, Souza-Filho JP, Ferigolo J. 2017. Tropical fossil caviomorph rodents from the southwestern Brazilian Amazonia in the context of the South American faunas: systematics, biochronology, and paleobiogeography. J Mamm Evol. 24:5770. 
Kramarz AG. 1998. Un nuevo dasyproctidae (Rodentia, Caviomorpha) del Mioceno inferior de Patagonia. Ameghiniana. 35:181-192.

Kramarz AG. 2001a. Un nuevo roedor Adelphomyinae (Hystricognathi, Echimyidae) del Mioceno Medio-Inferior de Patagonia, Argentina. Ameghiniana. 38:163-168.

Kramarz AG. 2001b. Registro de Eoviscaccia (Rodentia, Chinchillidae) en estratos colhuehuapenses de Patagonia, Argentina. Ameghiniana. 38:237-242.

Kramarz AG. 2001c. Revision of the family Cephalomyidae (Rodentia, Caviomorpha) and new cephalomyids from the Early Miocene of Patagonia. Palaeovertebrata. 30:51-88.

Kramarz AG. 2004. Octodontoids and erethizontoids (Rodentia, Hystricognathi) from the Pinturas Formation, Early-Middle Miocene of Patagonia, Argentina. Ameghiniana. 41:199216.

Kramarz AG. 2005. A primitive cephalomyid hystricognath rodent from the early Miocene of northern Patagonia, Argentina. Acta Palaeontol Pol. 50:249-258.

Kramarz AG. 2006. Neoreomys and Scleromys (Rodentia, Hystricognathi) from the Pinturas Formation, late Early Miocene of Patagonia, Argentina. Rev Mus Argent Cienc Nat. 8:53-62.

Kramarz AG, Vucetich MG, Carlini AA, Ciancio MR, Abello MA, Deschamp CM, Gelfo JN. 2010. A new fauna at the top of the Gran Barranca sequence and its biochronological significance. In: Madden RH, Carlini AA, Vucetich MG, Kay RF, editors. The Paleontology of Gran Barranca, Evolution and Environmental Change through the Middle Cenozoic of Patagonia. Cambridge: Cambridge University Press; p. 264-277. 
Kramarz AG, Vucetich MG, Arnal M. 2013. A new Early Miocene chinchilloid hystricognath rodent; an approach to the understanding of the early chinchillid dental evolution. J Mamm Evol. 20:249-261.

Lavocat R. 1973. Les rongeurs du Miocène d'Afrique orientale. 1. Miocène inférieur. Mémoires et Travaux E.P.H.E. de l'Institut de Montpellier.

Lavocat R. 1976. Rongeurs caviomorphes de l'Oligocène de Bolivie. Rongeurs du bassin déséadien de Salla. Palaeovertebrata. 7:15-90.

Leidy J. 1871. Notice of some extinct rodents. Proc Acad Nat Sci Phila. 22:230-232.

Li CK, Zheng JJ, Ting S. Y. 1989. The skull of Cocomys linchaensis, an early Eocene ctenodactyloid rodent of Asia. In: Black CC, Dawson MR, editors. Papers on Fossil Rodents, in honor of Albert Elmer Wood. Los Angeles: Natural History Museum; p. 179-192.

Loomis FB. 1914. The Deseado Formation of Patagonia. New Hampshire: Rumford Press, Concord.

Marivaux L, Welcomme J-L. 2003. New diatomyid and baluchimyine rodents from the Oligocene of Pakistan (Bugti Hills, Balochistan): systematic and paleobiogeographic implications. J Vert Paleontol. 23:420-434.

Marivaux L, Benammi M, Ducrocq S, Jaeger J-J, Chaimanee Y. 2000. A new baluchimyine rodent from the Late Eocene of the Krabi Basin (Thailand): palaeobiogeographic and biochronologic implications. C R Acad Sci. 331:427-433.

Marivaux L, Welcomme J-L, Vianey-Liaud M, Jaeger J-J. 2002. The role of Asia in the origin and diversification of hystricognathous rodents. Zool Scr. 31:225-239. 
Martin T. 1994. On the systematic position of Chaetomys subspinosus (Rodentia:

Caviomorpha) based on evidence from the incisor enamel microstructure. J Mamm Evol. 2:117-131.

Meng J, Wyss AR. 2001. The morphology of Tribosphenomys (Rodentiaformes, Mammalia): phylogenetic implications for basal Glires. J Mamm Evol. 8:1-71.

Meng J, Li C, Beard KC, Gebo DL, Wang Y, Wang H. 2007a. New material of Alagomyidae (Mammalia, Glires) from the late Paleocene Subeng Locality, Inner Mongolia. Am Mus Novit. (3597):1-29.

Meng J, Li C, Ni X, Wang Y, Beard KC. 2007b. A new Eocene rodent from the Lower Arshanto Formation in the Nuhetingboerhe (Camp Margetts) area, Inner Mongolia. Am Mus Novit. (3569):1-18.

Patterson B, Pascual R. 1968. New echimyid rodents from the Oligocene of Patagonia, and a synopsis of the family. Breviora. 301:1-14.

Patterson B, Wood AE. 1982. Rodents from the Deseadan Oligocene of Bolivia and the relationships of the Caviomorpha. Bull Mus Comp Zool. 149:371-543.

Pérez ME, Vucetich MG. 2012. Asteromys punctus Ameghino (Rodentia, Hystricognathi, Cavioidea) from the Late Oligocene of Patagonia (Argentina) and the early evolution of Cavioidea sensu stricto. Ameghiniana. 49:118-125.

Pérez ME, Krause M, Vucetich MG. 2012. A new species of Chubutomys (Rodentia, Hystricognathi) from the late Oligocene of Patagonia and its implications on the early evolutionary history of Cavioidea sensu stricto. Geobios. 45:573-580. 
Pérez ME, Arnal M, Boivin M, Vucetich MG, Candela A, Busker F, Mamani Quispe B. New caviomorph rodents from the Late Oligocene of Salla, Bolivia: taxonomic, chronological, and biogeographic implications in the Deseadan faunas of South America. J Syst Palaeontol. DOI:

\subsection{0/14772019.2018.1471622.}

Sallam HM, Seiffert ER, Steiper ME, Simons EL. 2009. Fossil and molecular evidence constrain scenarios for the early evolutionary and biogeographic history of hystricognathous rodents. Proc Natl Acad Sci USA. 106:16722-16727.

Sallam HM, Seiffert ER, Simons EL. 2011. Craniodental morphology and systematics of a new family of hystricognathous rodents (Gaudeamuridae) from the Late Eocene and Early Oligocene of Egypt. PLoS One. 6, e16525.

Sallam HM, Seiffert ER, Simons EL. 2012. A basal phiomorph (Rodentia, Hystricognathi) from the Late Eocene of the Fayum Depression, Egypt. Swiss J Palaeontol. 131:283-301.

Shockey BJ, Salas-Gismondi R, Gans PB, Jeong A, Flynn JJ. 2009. Paleontology and geochronology of the Deseadan (late Oligocene) of Moquegua, Peru. Am Mus Novit. (3668):1-24.

Vucetich MG. 1989. Rodents (Mammalia) of the Lacayani fauna revisited (Deseadan, Bolivia). Comparison with new Chinchillidae and Cephalomyidae from Argentina. Bull. Mus. Natl. Hist. Nat. Paris, 4:233-247.

Vucetich MG, Bond M. 1984. Un nuevo Octodontoidea (Rodentia, Caviomorpha) del Oligoceno tardío de la provincia de Chubut (Argentina). Ameghiniana. 21:105-114. 
Vucetich MG, Kramarz AG. 2003. New Miocene rodents of Patagonia (Argentina) and their bearing in the early radiation of the octodontoids (Hystricognathi). J Vert Paleontol. 23:435444.

Vucetich MG, Ribeiro AM. 2003. A new and primitive rodent from the Tremembé Formation (Late Oligocene) of Brazil, with comments on the morphology of the lower premolars of caviomorph rodents. Rev Bras Paleontolog. 5:73-82.

Vucetich MG, Verzi DH. 1991. Un nuevo Echimyidae (Rodentia, Hystricognathi) de la edad Colhuehuapense de Patagonia y consideraciones sobre la sistemática de la familia. Ameghiniana. 28:67-74.

Vucetich MG, Verzi DH. 1994. Las homologías en los diseños oclusales de los roedores Caviomorpha: un modelo alternativo. Mastozool neotrop. 1:61-72.

Vucetich MG, Verzi DH. 1996. A peculiar octodontoid (Rodentia, Caviomorpha) with terraced molars from the Lower Miocene of Patagonia (Argentina). J Vert Paleontol. 16:297302.

Vucetich MG, Vieytes EC. 2006. A Middle Miocene primitive octodontoid rodent and its bearing on the early evolutionary history of the Octodontoidea. Palaeontogr Abt A. 27:81-91.

Vucetich MG, Verzi DH, Dozo MT. 1992. El 'status’ sistemático de Gaimanomys alwinea (Rodentia, Caviomorpha, Echimyidae). Ameghiniana. 29:85-86.

Vucetich MG, Souza Cunha FL de, Alvarenga HMF de. 1993a. Un Roedor Caviomorpha de la Formación Tremembé (Cuenca de Taubaté), Estado de Sao Paulo, Brasil. An Acad Bras Ciênc. 65:247-251. 
Vucetich MG, Mazzoni MM, Pardiñas UFJ. 1993b. Los roedores de la Formación Collón Cura (Mioceno Medio), y la ignimbrita Pilcaniyeu. Cañadón del Tordillo, Neuquen. Ameghiniana. 30:361-381.

Vucetich MG, Vieytes EC, Pérez ME, Carlini AA. 2010a. The rodents from La Cantera and the early evolution of caviomorphs in South America. In: Madden RH, Carlini AA, Vucetich MG, Kay RF, editors. The Paleontology of Gran Barranca, Evolution and Environmental Change through the Middle Cenozoic of Patagonia. Cambridge: Cambridge University Press; p. 189-201.

Vucetich MG, Kramarz AG, Candela AM. 2010b. Colhuehuapian rodents from Gran Barranca and other Patagonian localities: the state of the art. In: Madden RH, Carlini AA, Vucetich MG, Kay RF, editors. The Paleontology of Gran Barranca, Evolution and Environmental Change through the Middle Cenozoic of Patagonia. Cambridge: Cambridge University Press; p. 206-219.

Vucetich MG, Dozo MT, Arnal M, Pérez ME. 2015. New rodents (Mammalia) from the Late Oligocene of Cabeza Blanca (Chubut) and the first rodent radiation in Patagonia. Hist Biol. $27: 236-257$.

Walton AH. 1990. Rodents of the La Venta Fauna, Miocene, Colombia: biostratigraphy and paleoenvironmental implications. Unpublished Ph.D. Thesis, Southern Methodist University, Dallas, USA.

Walton AH. 1997. Rodents. In: Kay RF, Madden RH, Cifelli RL, Flynn JJ, editors. Vertebrate paleontology in the Neotropics. The Miocene Fauna of La Venta, Colombia. Washington and London: Smithsonian Institution Press; p. 392-409. 
Wood AE. 1949. A new Oligocene rodent genus from Patagonia. Am Mus Novit. (1435):154.

Wood AE. 1962. The early Tertiary rodents of the family Paramyidae. Trans Am Philos Soc. 52:1-261.

Wood AE. 1968. Early Cenozoic mammalian faunas, Fayum Province, Egypt, Part II: the African Oligocene Rodentia. Peabody Mus Nat Hist. 28:23-105.

Wood AE, Patterson B. 1959. The rodents of the Deseadan Oligocene of Patagonia and the beginnings of South American rodent evolution. Bull Mus Comp Zool. 120:281-428.

Wyss AR, Flynn JJ, Norell MA, Swisher CC III, Charrier R, Novacek MJ, McKenna MC. 1993. South America's earliest rodent and recognition of a new interval of mammalian evolution. Nature. 365:434-437. 